BENJAMIN AUSTIN

Harvard University

EDWARD GLAESER

Harvard University

LAWRENCE SUMMERS

Harvard University

\title{
Jobs for the Heartland: Place-Based Policies in 21st-Century America
}

ABSTRACT The economic convergence of U.S. regions has slowed greatly, and rates of long-term nonemployment have even been diverging. Simultaneously, the rate of nonemployment for working age men has nearly tripled over the last 50 years, generating a social problem that is disproportionately centered in the eastern parts of the American heartland. Should more permanent economic divisions across space lead U.S. economists to rethink their traditional skepticism about place-based policies? We document that increases in labor demand appear to have greater effects on employment in areas where not working has been historically high, suggesting that subsidizing employment in such places could reduce the rate of not working. Proemployment policies, such as a ramped-up Earned Income Tax Credit, that are targeted toward regions with more elastic employment responses, however financed, could plausibly reduce suffering and materially improve economic performance.

o America's profound spatial economic disparities require spatially targeted policies? Traditionally, economists have been skeptical about these policies because of a conviction that relief is best targeted toward poor people rather than poor places, because incomes in poor areas were

Conflict of Interest Disclosure: The authors received financial support for this work from the Smith Richardson Foundation. With the exception of the aforementioned, they did not receive financial support from any firm or person for this paper or from any firm or person with a financial or political interest in this paper. With the exception of the aforementioned, they are currently not officers, directors, or board members of any organization with an interest in this paper. No outside party had the right to review this paper before publication. 
converging toward incomes in rich areas anyway, and because of fears that favoring one location would impoverish another. In this paper, we argue for reconsidering place-based policies, because (i) convergence has stalled or reversed in recent decades; (ii) social problems are increasingly linked to a lack of jobs rather than a lack of income, and subsidizing job creation may be easier at the place level than at the person level; and (iii) a modest body of evidence suggests that increasing the demand for labor has a materially greater impact on nonemployment in depressed areas. Place-based policies can take the form of more generous employment subsidies in depressed areas, which provide implicit insurance against place-based shocks but distort migration decisions, or equivalently generous policies that tilt existing programs to encourage employment in areas with more joblessness.

America's regions have long displayed enormous economic disparities, but for most of the 20th century, poorer states were catching up rapidly (Barro and Sala-i-Martin 1991) and high local unemployment rates did not persist (Blanchard and Katz 1992). Migration flowed to high-income regions, and capital was attracted by low wages in poorer areas. Both flows helped incomes to converge.

In recent decades, regional income convergence has slowed or even reversed (Berry and Glaeser 2005; Moretti 2011), and place-based nonemployment has become durable. Over the past 40 years, migration has stopped flowing to high-income regions and has declined more generally (Ganong and Shoag 2017). Economic divisions across space loom as the backdrop to our political divisions (Autor and others 2017).

In section I of this paper, we document the hardening of America's geographic divisions, and the rise of nonemployment among men age 25-54, who are the focus of this paper. Many measures of well-being suggest that not working is a far worse outcome than low-income employment, which motivates our focus on employment rather than income. ${ }^{1}$ Regional disparities in joblessness are large. In 2016, the nonemployment rate for men age 25-54 was over 35 percent in Flint, Michigan, and was 5 percent in Alexandria, Virginia.

We divide the United States into three regions based on year of statehood: the prosperous coasts, the western heartland, and the eastern heartland. The coasts have high incomes, but the western heartland also benefits from natural resources and historically high levels of education. America's social problems - including nonemployment, disability, opioid-related deaths, and

1. Eberstadt (2016) and the Council of Economic Advisers (2016) both provide excellent overviews of the rise in nonemployment among prime age males. 
rising mortality - are concentrated in America's eastern heartland, states from Mississippi to Michigan, generally east of the Mississippi River and not on the Atlantic Coast. The income and employment gaps between the three regions are not converging, but instead seem to be hardening into semipermanent examples of economic hysteresis.

The European Union has long embraced place-based policies that target distressed areas, but U.S. national policy has typically adopted geographic uniformity. Place-based policies are popular with place-based politicians, but economists often emphasize that a national perspective pushes toward helping poor people, not helping poor places. In section II, we analyze the economic rationales for place-based policies.

An abundant body of literature documents agglomeration economies and human capital externalities (Duranton and Puga 2004; Combes, Duranton, and Gobillon 2008; Moretti 2011). Although such externalities suggest market failure, they do not imply any particular spatial policy. Both New York and Appalachia might benefit from more economic activity and more skilled residents, but we do not know if it is optimal to shift skills and density from New York to Appalachia or vice versa.

A second justification for place-based policies is to insure residents against place-based economic shocks, just as the federal government already provides some insurance against place-based natural disasters. In 1969, Detroit residents had higher incomes than Boston residents, but today Boston residents are 40 percent wealthier. ${ }^{2}$ But smoothing income differences across states would only modestly reduce income inequality. Controlling for states explains only 1.1 percent of the variation in income levels; even the smaller Public Use Microdata Areas (PUMAs) can explain only 6.6 percent of the variation in income. Smoothing income differences across smaller geographic areas would distort migration, raise housing costs in low-income areas, and potentially even concentrate poverty.

The most compelling case for place-based policies is that one-size-fits-all interventions are woefully inappropriate for regional economies as diverse as Appalachia and Silicon Valley. Subsidizing employment, either at the individual or firm level, makes little sense in an economy as robust as that of the San Francisco Bay Area, where the restricted housing supply limits

2. Place of birth has a strong impact on economic opportunity (Chetty and Hendren, forthcoming). Almost 50 years ago, in 1969, the U.S. Bureau of Economic Analysis also listed Stamford, Conn., as the wealthiest metropolitan area and McAllen, Tex., as the poorest. In that year, Stamford was almost three times as rich as McAllen. In 2016, America's richest metropolitan areas (Stamford and Midland, Tex.) were four times richer than the poorest (McAllen). 
future population growth. If nonemployment is much more sensitive to subsidies in West Virginia, then larger proemployment subsidies in that state seem likely to reduce suffering more.

Place-based policies need not mean large-scale transfers to distressed areas, but instead the tailoring of policies to particular locales. For example, a bevy of current social welfare policies-including the Housing Choice Voucher Program (Section 8), the Supplemental Nutritional Assistance Program, and disability insurance-currently implicitly tax earnings. The implicit taxes on housing vouchers and food stamps could be reduced for low-income workers from 30 percent to 20 percent in areas where employment is particularly responsive to the returns to working.

Indeed, even the most die-hard opponent of place-based redistribution should see the logic of tailoring federal policies to local labor market conditions. Standard social policy rules, like the Baily-Chetty formula for unemployment insurance (Baily 1978; Chetty 2006), depend on parameters that differ across space. If nonemployment is particularly harmful in one location and particularly sensitive to public policies, then that die-hard opponent could still support a place-based, revenue-neutral twist that reallocates funds from benefits that discourage working to benefits that encourage employment in that area, without encouraging migration or raising housing prices.

We use a modified Baily-Chetty formula to analyze benefits for the not working and for marginal workers. The formula depends on two parameters: the ratio of the externalities associated with nonemployment to the wages of low-income workers, and the heterogeneous response of employment rates to policy interventions. In section III, we look for heterogeneous responses by testing whether exogenous shocks reduce nonemployment more in high nonemployment states.

We first use industrial-composition Bartik shocks. These shocks do reduce not-working rates more in states where the average not-working rate is higher. China trade shocks—as identified by David Autor, David Dorn, and Gordon Hanson (2013)—also have an impact on not-working rates more in commuting zones with historically higher levels of nonemployment. Military spending shocks, used by Emi Nakamura and Jón Steinsson (2014), also have a larger impact on not-working rates in states where the average not-working rate is higher, but the difference is statistically insignificant. Our results are far from definitive, but they do support the perfectly unsurprising view that you can reduce nonemployment more in places where nonemployment is currently high. We hope that future research will do more to examine spatial heterogeneity in 
labor supply elasticities, and the regional heterogeneity of labor markets more broadly.

Section IV follows Robert Gordon (1973) and focuses on the externalities of nonemployment, which include fiscal costs to the state, costs borne by friends and family, and possibly also spillovers that encourage more nonemployment (Topa 2001). We calibrate these costs to range from 0.21 to 0.36 times the typical wages earned by low-income workers, but recognize that these numbers are quite debatable. Using these estimates, section $\mathrm{V}$ calibrates our model, which suggests that the generosity of proemployment programs relative to nonemployment benefits should be higher in West Virginia than in Nebraska. The modified Baily-Chetty formula also implies that subsidies should skew more toward employment in regions of high employment elasticity when the coefficient of relative risk aversion is low.

Section VI turns to a taxonomy of place-based policies, and discusses their costs and benefits-including distorted mobility, capitalization, and other deadweight losses. ${ }^{3}$ Empowerment Zones subsidize employment in high-poverty areas, and Matias Busso, Jesse Gregory, and Patrick Kline (2013) find them to be effective. ${ }^{4}$ Attempts to use infrastructure to help depressed cities, such as the Detroit People Mover, have had results that are far less encouraging. But infrastructure, like that built by the Tennessee Valley Authority, that actually delivers a scarce and enormously valuable resource, such as electricity, can have large economic effects (Kline and Moretti 2013). Conversely, the Appalachian Regional Commission, which provides a potpourri of placed-based support, including highways, seems to have done little to change the region's fortunes.

We end with a discussion of plausible policies that account for spatial heterogeneity in employment responses. We discuss strengthening employment subsidies, either to the firm or to the worker, in states with high nonemployment. The employment effects of paying subsidies to the firm, rather than the worker, will be stronger if workers' wages face a lower minimum wage bound. We discuss tilting the incentives that community colleges face to provide job counseling and employment-appropriate vocational skills.

3. The impact of spatially heterogeneous policies on migration is a long-standing question in antipoverty policy, and much of the best work on this topic preceded welfare reform, when state differences in payments for Aid to Families with Dependent Children could be quite large (Borjas and Hilton 1996).

4. Busso, Gregory, and Kline (2013) also find that Empowerment Zones do seem to get capitalized into housing prices, especially in depressed areas, but evidence for capitalization into rents is weaker. 
A wide body of literature suggests that education combats joblessness at both the individual and regional levels, and investing in education is a natural complement to subsidizing employment. Finally, we mention policies that might have benign spatial effects even if they are apparently neutral. A flat per-dollar employment subsidy would presumably have a larger effect in low-cost states where prices are lower.

\section{The Geography of Jobless America}

A belief in individual upward mobility reduces the desire for income redistribution (Alesina, Miano, and Stantcheva, forthcoming). Similarly, a belief in the upward mobility of regions limits the demand for place-based policies. America has long tolerated dramatic economic differences across space, partially because people regularly moved from poor places to rich places and capital flowed freely from high-wage to low-wage areas. In this section, we document five trends suggesting that this mobility has fallen considerably and that America appears to be evolving into durable islands of wealth and poverty. At the broadest level, the nation can be divided into its wealthy, costly coasts; a reasonably successful western heartland; and a painfully jobless eastern heartland. These differences are driven mainly by historical differences in human capital and the economic dislocation caused by deindustrialization.

\section{I.A. The Closing of the Metropolitan Frontier}

The United States has long been a nation with enormous spatial differences in income. In 1950, 18 states in the continental United States had per capita earnings that were double the per capita earnings of Mississippi. In 2016, Mississippi is still the nation's poorest state, but there is no state with double its per capita income. Many of Mississippi's poorest residents went north to the factories of Chicago and Detroit (Smith and Welch 1989). Industry flowed south, encouraged by probusiness policies, like right-towork laws (Holmes 1998). America's western frontier may have closed at the end of the 19th century, but there was still a metropolitan frontier where workers from depressed areas could find a more prosperous future.

Five facts collectively suggest that this geographic escape valve has tightened: (i) declining geographic mobility, (ii) increasingly inelastic housing supplies in high-income areas, (iii) declining income convergence, (iv) increased sorting by skills across space, and (v) persistent pockets of nonemployment. Together, these facts suggest that even if income differences across space have declined, the remaining economic differences may 
Figure 1. The Decline in Migration Rates, 1950-2016

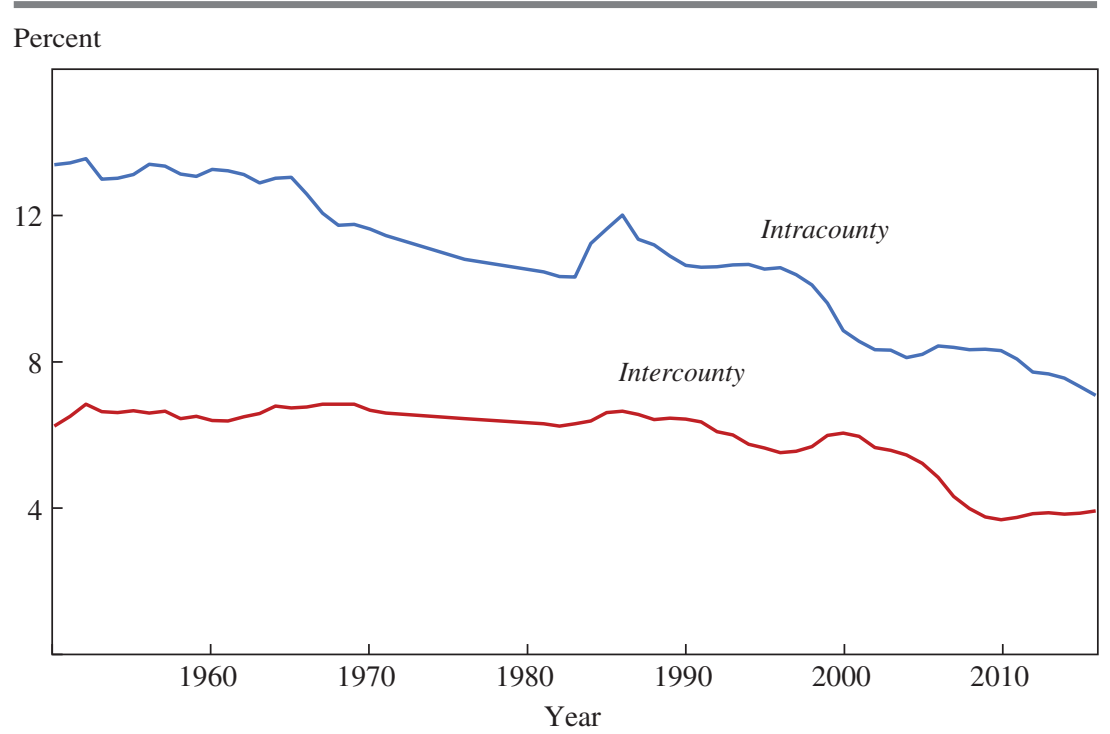

Sources: U.S. Census Bureau, Annual Geographical Mobility Rates; authors' calculations.

a. The series are three-year moving averages for U.S. households. Data are missing for 1972-75 and 1977-80.

be a greater source of concern. Consequently, it may be time to target proemployment policies toward the most distressed areas.

Figure 1 shows that between 1950 and 1992, intercounty mobility never dropped below 6 percent. Since 2008, the share of U.S. residents who moved across counties never exceeded 3.9 percent. The first steep drop occurred between 1990 and 1995, and then another dip occurred after 2005. This decline in cross-county mobility is mirrored by the drop in the withincounty mobility rate, which fell from over 13 percent in the 1950s to 7 percent. Declining mobility appears among both renters and owners; the change is not merely underwater borrowers held in place by their mortgages.

The great wave of postwar mobility included the Great Migration of African Americans north, the nationwide move to the Sunbelt, and massive suburbanization. In these previous migrations, as had been true throughout almost all of American history, housing was supplied abundantly to meet migrants' demand. Suburbanization itself can be seen as a massive shock to housing supply, generated by cars and highways (Baum-Snow 2007), that enabled African Americans coming north to occupy urban apartments (Boustan and Margo 2013). The growth of the Sunbelt reflects a combination 
of economic resurgence, the taste for warm weather, and few restrictions on the mass production of housing (Glaeser and Tobio 2008).

Moreover, the African American migrants to the north had little to lose by departing the Jim Crow South. As David Schleicher (2017) emphasizes, poorer Americans today are held in place by public benefits, such as housing vouchers, which can be difficult to carry across state or even county lines. Ostensibly, such federal programs as Medicaid and Temporary Assistance for Needy Families are administered at the state level. A move across states requires a new application that may not be approved.

Migration has both declined and become less directed toward highincome areas (Ganong and Shoag 2017). The unskilled flooded into highincome areas between 1940 and 1960, presumably bringing wages down, but they did not do so between 1980 and 2010. Mai Dao, Davide Furceri, and Prakash Loungani (2017) show that interstate migration due to labor market shocks has declined since the 1990s. Mike Zabek (2018) shows that stronger local ties to a region lead to lower migration rates in response to labor market shocks.

Low-income workers still receive significant wage gains from migrating to high-income areas, but the housing-related costs of moving to these areas have grown. Housing costs within skilled cities have risen particularly dramatically (Glaeser and Saiz 2004). Between 1978 and 2017, real housing prices in Detroit were relatively flat according to the Federal Housing Finance Agency's repeat sales index, while real housing prices increased in Boston by 200 percent and in San Francisco by 300 percent. Many authors associate higher housing prices with stringent land use regulations, especially in better-educated communities (Gyourko, Saiz, and Summers 2008; Glaeser and Ward 2009). ${ }^{5}$

Throughout most of U.S. history, economic productivity has been accompanied by a near-elastic housing supply. The settlers who moved to richer, western agricultural land in the 19th century built their own inexpensive, balloon-frame homes. The farmers and immigrants who came to Chicago in the 19th century readily piled into overcrowded tenements. New York City built over 100,000 units annually in the early 1920s, when the city experienced its post-World War I boom. Silicon Valley exploded as an

5. One plausible explanation for the relationship between regulation and education is that higher-skilled people are also better at organizing into groups that oppose new construction, such as the San Francisco Bay Area's Save the Bay initiative, which was cofounded by Catherine Kerr, the wife of Clark Kerr, the first chancellor of the University of California, Berkeley. 
Figure 2. College Graduation Rates of Migrants and Nonmigrants, $2000^{\mathrm{a}}$

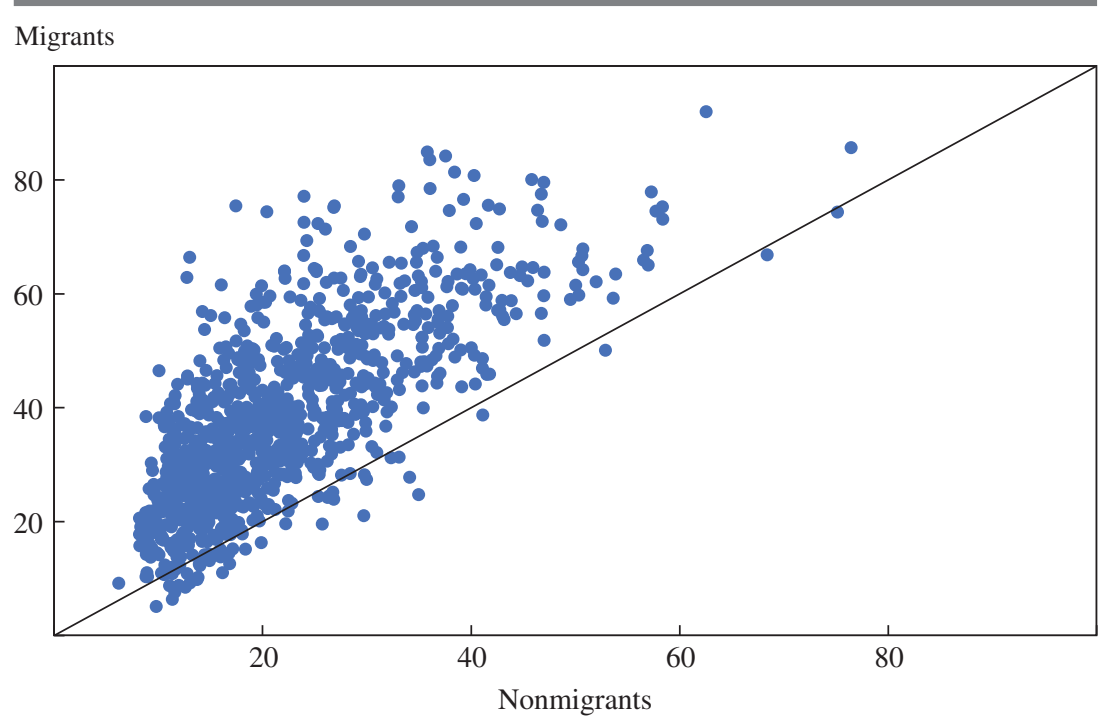

Sources: U.S. Census Bureau, 2000 census; IPUMS; authors' calculations.

a. The college graduation rate is defined as the share of respondents who report completion of four or more years of college. The sample includes civilian noninstitutionalized prime age men in the continental United States (excluding the District of Columbia), and excludes men living abroad in 1995. Interstate migrants are compared with men who lived in the same state five years earlier, and rates are calculated in terms of migration Public Use Microdata Areas. The diagonal line is at 45 degrees.

engine of American innovation, but it is practically synonymous with stringent land use restrictions, including some areas with 60-acre-minimum lot sizes. Chang-Tai Hsieh and Enrico Moretti (2017) estimate that these restrictions have led to a misallocation of labor that has significantly reduced America's overall GDP.

An additional barrier to interstate migration has been the rise of occupational licensing laws, which restrict the movement of workers across state lines. Janna Johnson and Morris Kleiner (2017) find that individuals in occupations with state-specific licensing requirements have a 36 percent lower rate of interstate migration than comparable workers in other occupations.

The skilled do still move toward higher-skill, higher-wage areas, helping to ensure that skilled areas are become more skilled over time. This is illustrated in figure 2, where we see that prime age male migrants are significantly better educated than the nonmigrant population in the PUMA that they left. 
Christopher Berry and Edward Glaeser (2005) report a robust correlation between the change across metropolitan areas in the percentage of the population with a college degree and the initial share of the population with a college degree in the 1970s, 1980s, and 1990s. The increasing segregation of skilled labor matters because the skill level of a locality is strongly correlated both with the levels of earnings for nonskilled workers (Moretti 2004), and with longer-term growth of incomes and population (Glaeser and Saiz 2004).

Increased geographic sorting by skill probably reflects a combination of restrictions that stymie the construction of affordable housing and workplace complementarities between educated employees. ${ }^{6}$ The innovations generated by highly skilled workers today appear increasingly to demand the labor of skilled workers rather than unskilled workers. Henry Ford's automated assembly lines depended on tens of thousands of less-skilled workers, and hence his skills strongly complemented less-skilled labor. Bill Gates's innovations primarily employed highly skilled software programmers.

Declining in-migration to high-wage areas has been accompanied by a decline in the convergence of incomes across states and metropolitan areas. Robert Barro and Xavier Sala-i-Martin (1991) document the striking convergence in per capita income levels across U.S. states between 1880 and 1980. This convergence is the backdrop for the shrinking gap between incomes in Mississippi and the rest of the United States. Berry and Glaeser (2005) show that by the 1990s, changes in metropolitan area incomes were no longer negatively correlated with initial per capita incomes. Peter Ganong and Daniel Shoag (2017) find that the relationship between state-level changes in per capita and initial per capita income was much weaker from 1990 to 2010 than from 1940 to 1960.

Figure 3 shows the convergence of log median personal incomes across 538 PUMAs between 1980 and 2010 for prime age men. The coefficient is -0.16 , which is far less than the -2.4 coefficient that Ganong and Shoag (2017) report for states between 1940 and 1960. Even that modest income convergence may be a spurious reflection of measurement error in the 1980 variable. When we instrument for log median income using the log of the 10th and 90th percentiles of income in 1980 (the $R^{2}$ of the first-stage regression is .85), we estimate

6. Berry and Glaeser (2005) find that the correlation across industries between the education levels of managers and the education level of workers increased significantly between 1970 and 2000, which supports the view that skilled workers increasingly complement each other at work. 
Figure 3. Median Income Growth, 1980-2010a

Change in log median income, 1980-2010

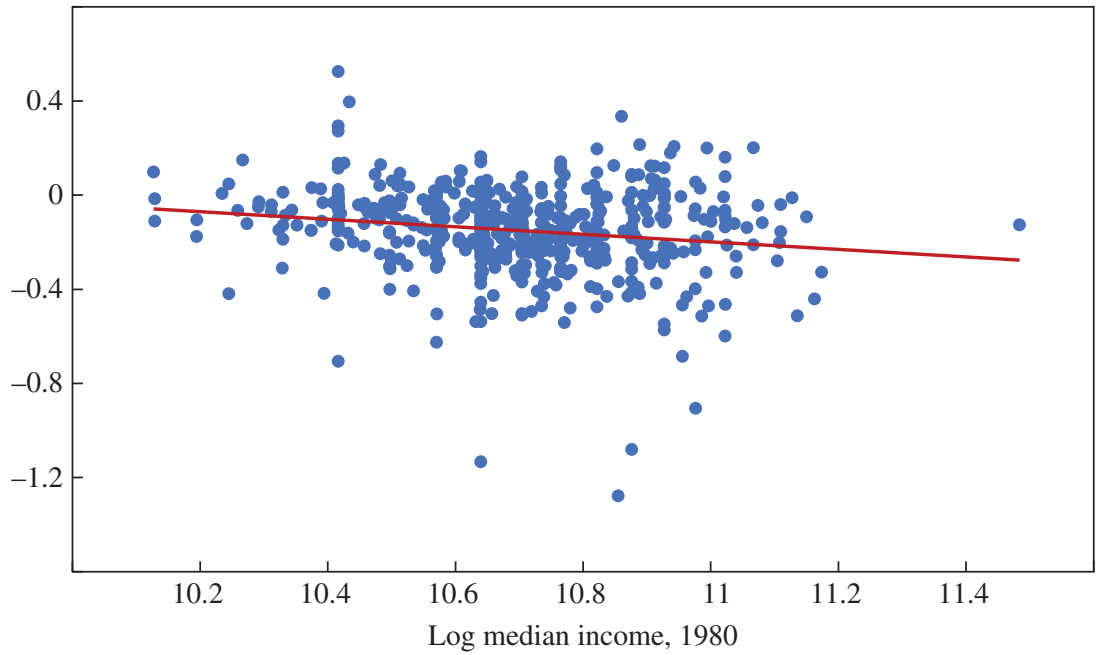

Sources: U.S. Census Bureau, 1980 census, American Community Survey; IPUMS; authors' calculations.

a. Median income is expressed in 2016 dollars. Data for 1980 are from the 1980 census; data for 2010 are pooled 2009-11 data from the American Community Survey. The sample includes civilian noninstitutionalized prime age men in 1980-2000 consistent Public Use Microdata Areas in the continental United States (excluding the District of Columbia).

$$
\log \left(\frac{\text { median }_{\text {income }_{2010}}}{{\text { median } \text { income }_{1980}}_{10}}\right)=\underset{(0.77)(0.07)}{-0.34+0.02 \times \log \left(\text { median income }_{1980}\right)} .
$$

Robust standard errors clustered by state are in parentheses. It seems plausible that true income convergence has also disappeared at the PUMA level.

\section{I.B. The Rise of Joblessness among Men}

The growth of geographic barriers within the United States has coincided with the dramatic increase in not-working rates among prime age men, which primarily reflects men leaving the labor force. The share of prime age men who are not in the labor force has grown from under 4 percent during the 1950 s to over 10 percent today. ${ }^{7}$

7. This is as shown in online appendix figure 1. Online appendix figure 2 shows a steady rise in prime age female labor force participation through the 1990s and then a leveling off. The online appendixes for this and all other papers in this volume may be found at the Brookings Papers web page, www.brookings.edu/bpea, under "Past BPEA Editions." 
Throughout this paper, we focus on the total rate of not working among prime age men, defined as men age 25-54, rather than unemployment or labor force participation. We define the nonemployment rate (or not-working rate) as the share of men who are not currently employed, or 1 minus the employment-to-population ratio for prime age men. We take the view that the distinction between unemployment and labor force nonparticipation is relatively arbitrary because almost all the not working would presumably work if the price were right (Clark and Summers 1979). In many cases, those who are not currently looking for a job will nevertheless return to employment in a short period of time.

When we examine prime age men entering the Current Population Survey (CPS) from 2014 to 2016, whose monthly responses can be linked for all eight months, we find that over half of men who left and reentered employment during the 16-month CPS window recorded at least one month that they were not in the labor force. ${ }^{8}$ John Coglianese (2017) refers to these men who leave and reenter the workforce as "in-and-outs," and we believe it is important to distinguish these men who are temporarily absent from the labor force from the long-term not working. In addition, the expanding role of disability insurance relative to unemployment insurance (Autor and Duggan 2003) may mean that an increasing share of individuals who would once have classified themselves as unemployed now list themselves as out of the labor force.

Olivier Blanchard and Lawrence Katz (1992) show a practically nonexistent relationship between the unemployment rate in 1975 and the unemployment rate in 1985 across states. This nonrelationship supports the idea that geographic differences in the not-working rate are a temporary phenomenon that is rapidly undone through migration and cyclical shocks. Figure 4 shows the relationship between the prime age male not-working rate in 2010 and the prime age male not-working rate in 1980 across PUMAs. The correlation between the two rates is .80. Moreover, the relationship shows diverging not-working rates because the coefficient on the 1980 not-working rate is 1.10 , which means that the growth in the notworking rate is positively associated with the initial not-working rate.

Figure 5 shows the time series of not-working men split into three categories: unemployed (not employed and actively seeking work), not in

8. The CPS consists of a 4-8-4 rotation structure, where households are interviewed for four months, rotate out of the panel for eight months, and are then interviewed for an additional four months. We use the method developed by Rivera Drew, Flood, and Warren (2014) to match respondents across months. 
Figure 4. The Persistence of Not-Working Rates, $1980-2010^{\mathrm{a}}$

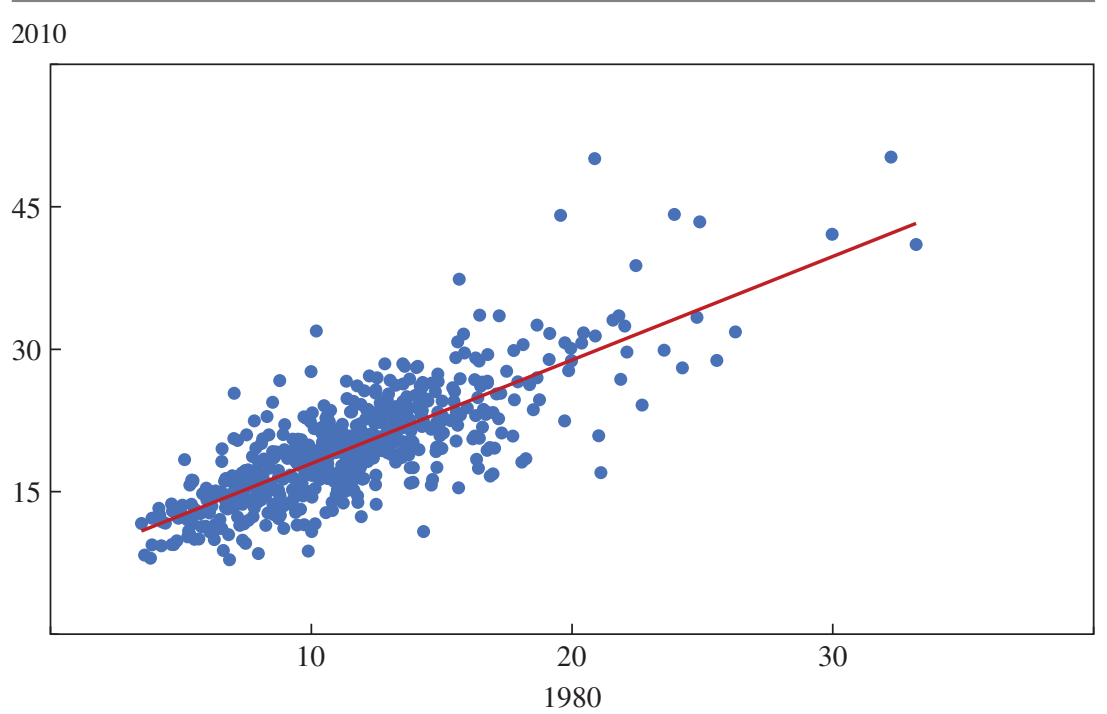

Sources: U.S. Census Bureau, 1980 census, American Community Survey; IPUMS; authors' calculations.

a. The not-working rate is defined as the share of the population currently not employed. Data for 1980 are from the 1980 census; data for 2010 are pooled 2009-11 data from the American Community Survey. The sample includes civilian noninstitutionalized prime age men in 1980-2000 consistent Public Use Microdata Areas in the continental United States (excluding the District of Columbia).

the labor force but wanting a job, and not in the labor force and not wanting a job. ${ }^{9}$ The share of prime age men who are not in the labor force and do not want a job shows a steady upward trend. The share that is unemployed undulates, severely peaking at 9 percent during the Great Recession. The third category, not in the labor force but still wanting a job, has held steady, at around 2 percent.

We prefer to focus on the distinction between the long-term and shortterm nonemployed, where being long-term nonemployed is more associated with leaving the labor force and being short-term nonemployed is more typically associated with unemployment. Figure 6 includes both the total not-working rate and the share of men who have been without a job for over a year, using data from the CPS's Annual Social and Economic Supplement (ASEC).

9. We note that some men who state they want a job may be unable to start a job immediately. However, we believe it is instructive to decompose not-working men into those who have a stated preference for future employment and those who do not. 
Figure 5. Components of the Not-Working Rate, 1995-2015

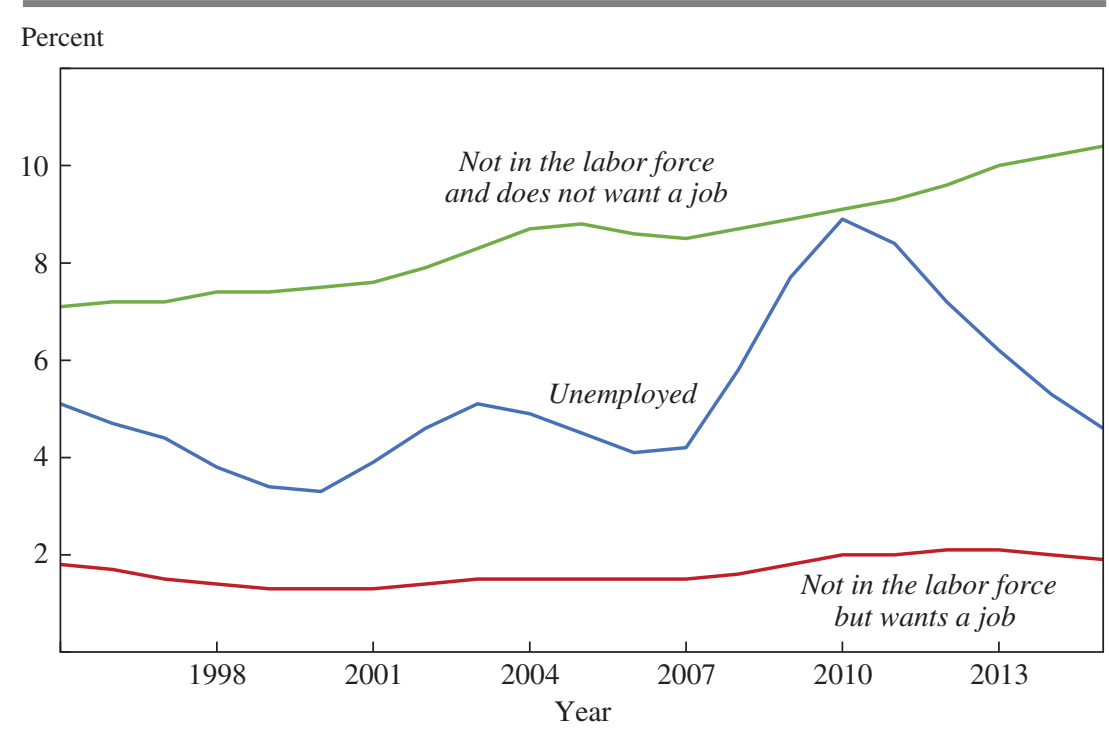

Sources: U.S. Census Bureau, Current Population Survey, Annual Social and Economic Supplement; IPUMS; authors' calculations.

a. The not-working rate is defined as the share of the population currently not employed. The series are three-year pooled moving averages. The sample includes civilian noninstitutionalized prime age men in the continental United States (excluding the District of Columbia).

\section{I.C. The Misery of Joblessness}

We focus on joblessness among prime age men, rather than income inequality, because we see it as a far greater problem. There is significant correlational evidence suggesting that misery haunts the lives of the longterm not working. Figure 7 shows life satisfaction rates by work status, using data from the Behavioral Risk Factor Surveillance System.

In figure 7 , we compare the not working with the employed with annual household earnings of more than $\$ 50,000$ per year, the employed with annual household earnings of $\$ 35,000$ to $\$ 50,000$ per year, and the employed with annual household earnings of less than $\$ 35,000$ per year, and show the share of the male population in each group that reports a low level of life satisfaction. This number is quite low among those earning more than $\$ 35,000$ per year. Low life satisfaction rises for those who are employed but earning less than $\$ 35,000$ per year, but low life satisfaction is much higher among those who are not employed. Almost 20 percent of the not working in the eastern heartland report a low level of life satisfaction. 
Figure 6. Overall and Long-Term Not-Working Rates, 1980-2015

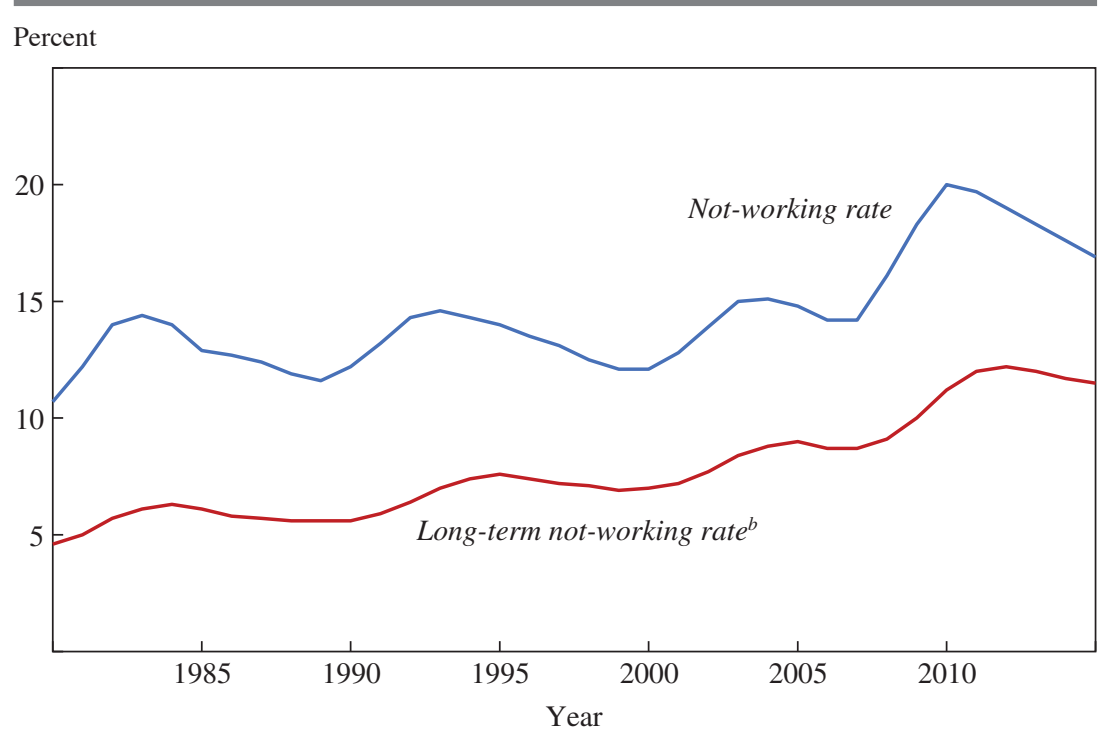

Sources: U.S. Census Bureau, Current Population Survey, Annual Social and Economic Supplement; IPUMS; authors' calculations.

a. The not-working rate is defined as the share of the population currently not employed. The series are three-year pooled moving averages. The sample includes civilian noninstitutionalized prime age men in the continental United States (excluding the District of Columbia).

b. Long term is defined as more than 12 months.

Andrew Clark and Andrew Oswald (1994) report that unemployment has a much more negative effect on happiness than low earnings. André Hajek (2013) estimates the relationship between unemployment and unhappiness with individual fixed effects and finds a significant negative effect, especially if the unemployment is described as involuntary. Rainer Winkelmann (2014) similarly finds that happiness drops significantly after an individual becomes unemployed.

Happiness is not equivalent to utility. Parents of young children, for example, are typically less happy, but they are presumably compensated in other ways. ${ }^{10}$ Yet it is hard to see what benefit is offsetting unhappiness among the not working.

Nonemployment is also strongly correlated with mental health problems. A large body of literature, surveyed by Stephen Platt (1984), connects

10. The residents of rust belt cities were less happy during the 1940s and 1970s, but they were presumably compensated by higher wages (Glaeser, Gottlieb, and Ziv 2016). 
Figure 7. Life Dissatisfaction Rates, 2005-10

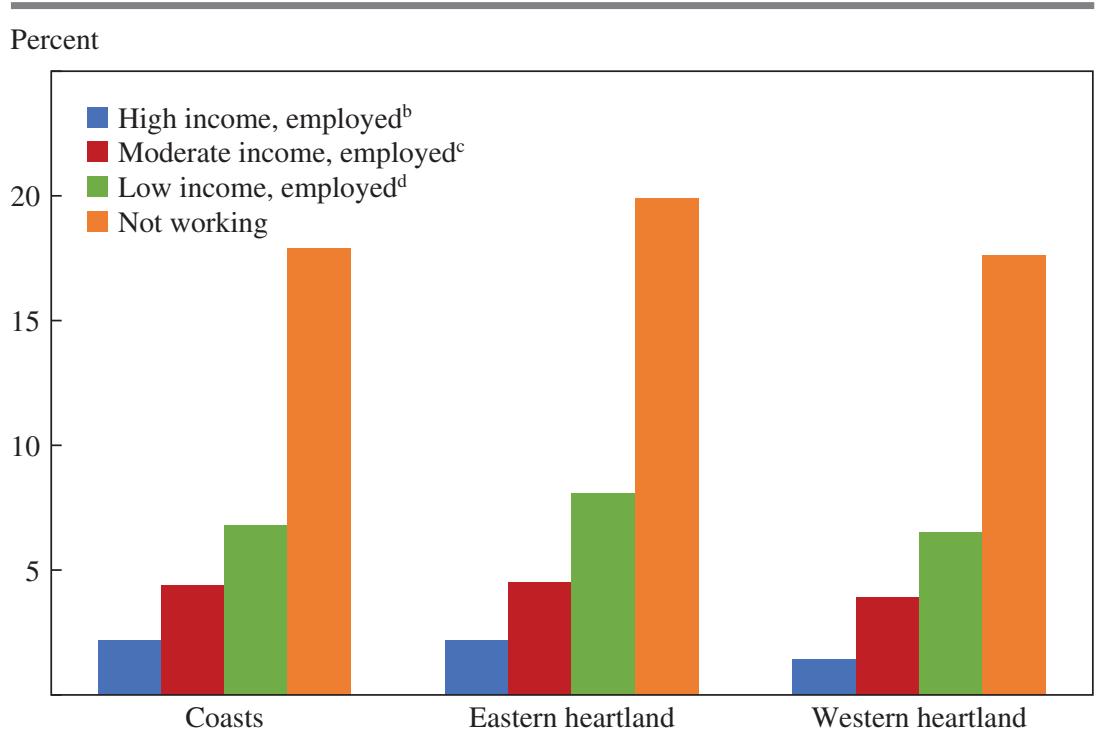

Sources: U.S. Centers for Disease Control and Prevention, Behavioral Risk Factor Surveillance System; authors' calculations.

a. The life dissatisfaction rate is the share of respondents who report being "dissatisfied" or "very dissatisfied" with life. The data are pooled over 2005-10. The sample includes civilian noninstitutionalized prime age men in the continental United States (excluding the District of Columbia).

b. High income is defined as household income of more than $\$ 50,000$ per year.

c. Moderate income is defined as household income between $\$ 35,000$ and $\$ 50,000$ per year.

d. Low income is defined as household income of less than $\$ 35,000$ per year.

suicide and unemployment. More recent studies include those by Augustine Kposowa (2001) and by Tony Blakely, Sunny Collings, and June Atkinson (2003). Over 30 percent of the not working report having more than 10 days of poor mental health in the past month. Once again, the gap between the not working and the poor-but-employed is much larger than the gap between poor and rich employed workers.

Opioid use is another marker of pain associated with nonemployment, as highlighted by Alan Krueger (2017). Like suicide, opioid use may be another consequence of nonemployment. Because opioids can also lead to addiction and death, they are an added cause of social pain.

\section{I.D. The Geography of Joblessness}

We now turn to the geography of joblessness in the United States. We begin with two maps of the United States showing the geography of prime 
Figure 8. Not-Working Rates, 1980a

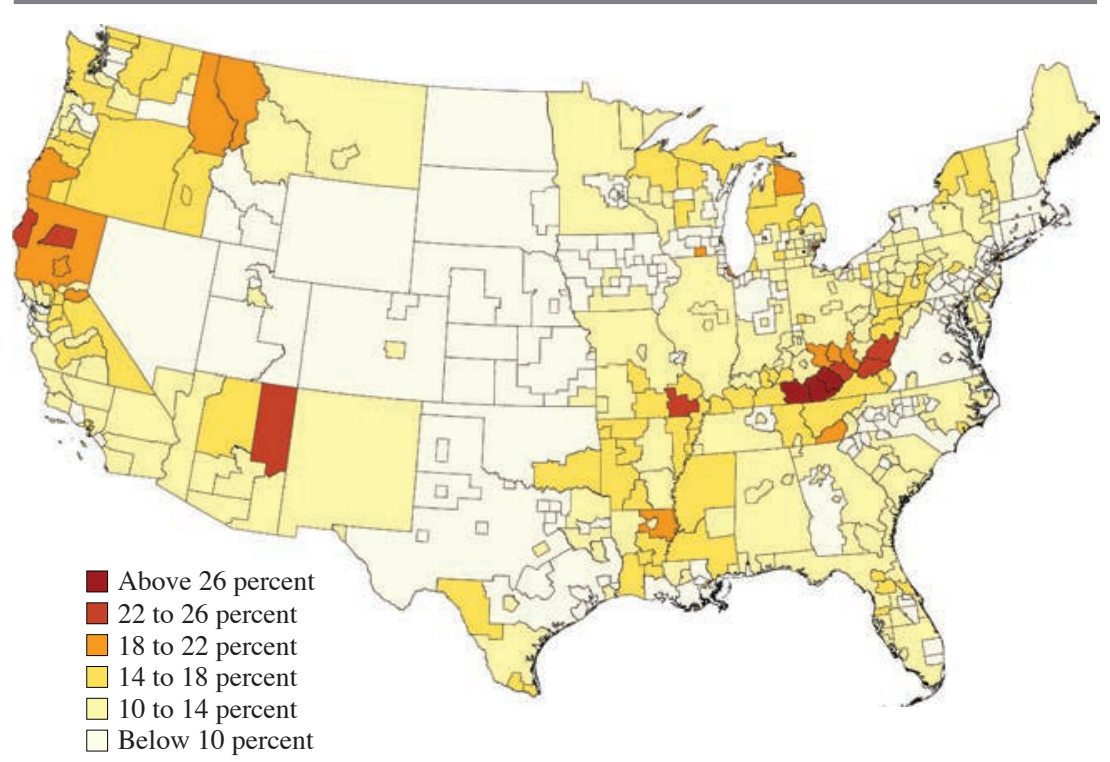

Sources: U.S. Census Bureau, 1980 census; IPUMS; authors' calculations.

a. The not-working rate is defined as the share of the population currently not employed. The sample includes civilian noninstitutionalized prime age men in 1980-2000 consistent Public Use Microdata Areas in the continental United States.

age male nonemployment in 1980 and 2015. The 1980 data come from the decennial census, and the 2015 data are based on three years of the American Community Survey (2014-16). ${ }^{11}$ We use consistent PUMAs.

Figure 8 shows that fewer than 10 percent of men were not employed in 1980 in much of the western United States and in the northeastern corridor. Coastal California and much of the Midwest and Southeast had nonemployment rates between 10 and 15 percent. Rates over 15 percent were only seen in Appalachia and a few isolated parts of lower-density America, including a PUMA in Arizona, upstate New York, and a few parts of California.

11. There are slight population differences between decennial census data, which were used to create the 1980 map, and American Community Survey data, which were used to create the 2015 maps. Moreover, the 2015 PUMAs are defined differently than the consistent PUMAs used from 1980 to 2010 . The maps look broadly similar using 2010 data and consistent 1980-2010 PUMAs. 
Figure 9. Not-Working Rates, 2015

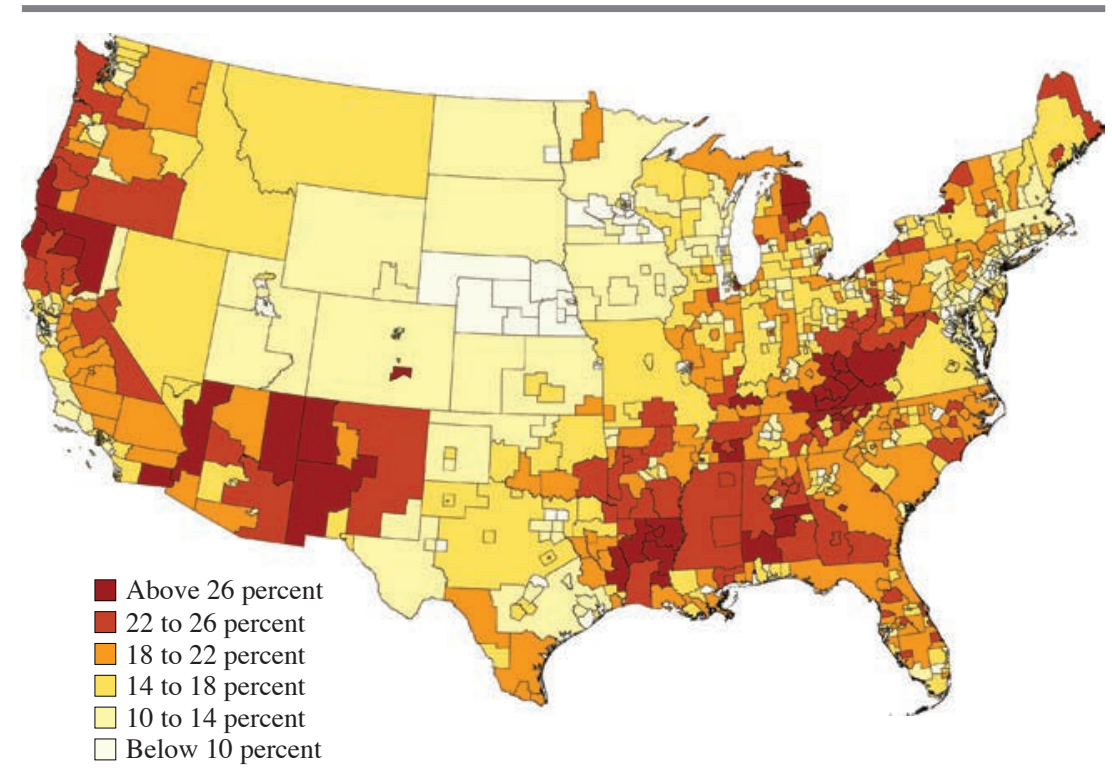

Sources: U.S. Census Bureau, American Community Survey; IPUMS; authors' calculations.

a. The not-working rate is defined as the share of the population currently not employed. The data are pooled over 2014-16. The sample includes civilian noninstitutionalized prime age men in 2000-10 consistent Public Use Microdata Areas in the continental United States.

Figure 9 shows that in 2015 the nonemployment rate has risen almost everywhere, but people in the northeastern corridor and much of the western United States still remain relatively more employed. Nonemployment is high in the Far West-except for the areas around Los Angeles, San Francisco, and Seattle — and in a great swath of Middle America that runs from Louisiana up to Michigan. Appalachia remains a place of tremendous economic dysfunction.

Women are more likely to work in northern areas, whether in the East or the West, and are less likely to work in southern areas. ${ }^{12}$ If we regress the change in prime age male not-working rates on the change in prime age female not-working rates at the PUMA level between 1980 and 2010, we find that the $R^{2}$ is only .094 . These differences seem as likely to be driven

12. Online appendix figure 5 shows a map of prime age female not-working rates in 2015 . Online appendix figure 4 shows that in 1980, female nonemployment was more common everywhere and was particularly high in Appalachia. 
Figure 10. The Change in the Long-Term Not-Working Rate, 1980-2014a

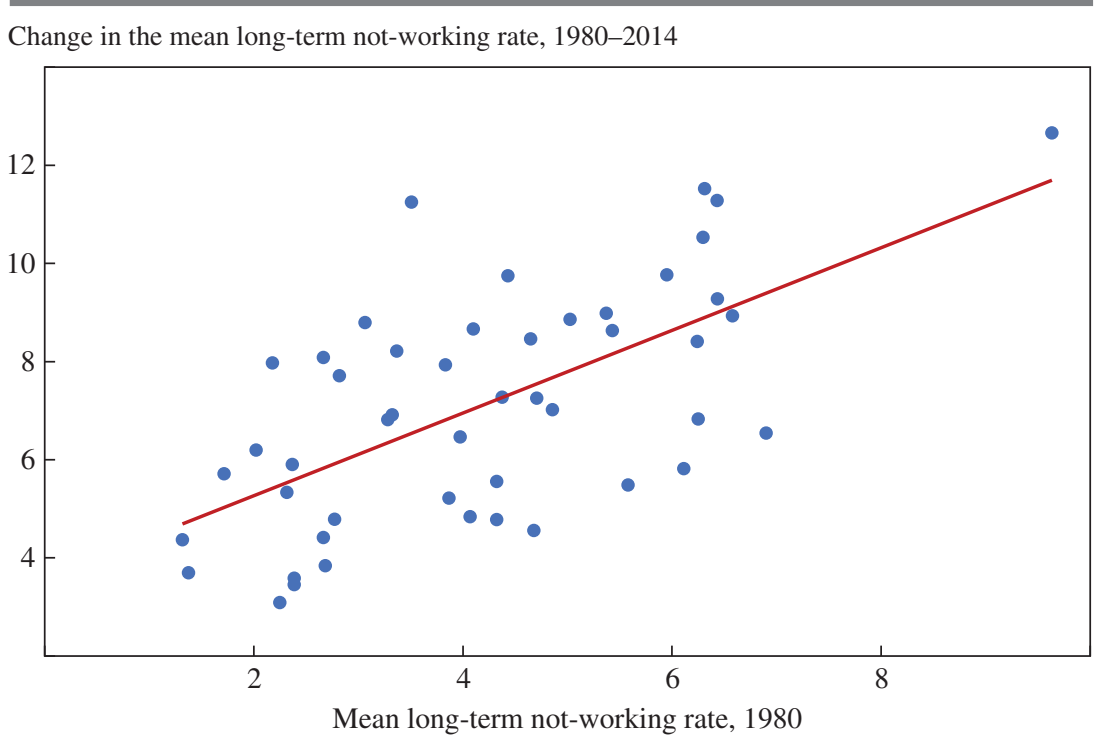

Sources: U.S. Census Bureau, Current Population Survey, Annual Social and Economic Supplement; IPUMS; authors' calculations.

a. The not-working rate is defined as the share of the population currently not employed. Long term is defined as more than 12 months. The data are three-year pooled moving averages. The sample includes civilian noninstitutionalized prime age men in the continental United States (excluding the District of Columbia).

by cultural norms as by economic distress. The shifts in male and female employment are not particularly correlated with one another, meaning that the declining male employment rates reflect economic distress that does not seem to be offset by increases in female labor force participation.

Figure 10 looks at the long-term (more than 12 months) not-working rate, and shows that there has also been strong divergence since 1980. For every extra percentage point of men who were long-term not working in 1980 (the first year we can calculate this number), the growth in long-term not working increases by 0.84 percentage point between 1980 and $2014 .{ }^{13}$ Robert Hall (1972) documented that unemployment was slightly higher in higher-wage cities, suggesting that workers were being compensated for a greater risk of being unemployed; but today, the relationship between nonemployment and income is strongly negative.

13. Online appendix figures 6 and 7 show the convergence of nonemployment rates at the state level, which has gotten weaker over time. 
These previous maps inspire our division of America into three groups: the coastal states, the eastern heartland, and the western heartland. The PUMA maps suggest that many states could likewise be usefully divided. Inland California looks quite different from the San Francisco Bay Area. Yet many data sources contain only state identifiers, so we use state boundaries. We refer to states formed before 1840 as the eastern heartland, and to those formed after 1840 as the western heartland. ${ }^{14}$

The coastal states have seen their real economies grow by 342 percent from 1965 to 2016 . The western heartland has grown by 475 percent over the same period. The eastern heartland has experienced the most sluggish growth, at 187 percent. $^{15}$

The parallel growth in GDP between the coasts and the western heartland can be divided into growth in GDP per worker and growth in the number of workers. Although per capita GDP growth has been faster on the coasts, employment growth has been much faster in the western heartland. The difference may reflect the far more elastic housing supply in the western heartland, which welcomes workers in response to rising productivity.

The trends in GDP are matched by the trends in the not-working rate. Figure 11 shows the prime age male not-working rate since 1980. Before the recession of the early 1980s, nonemployment was roughly comparable on the coasts and in the eastern heartland. The western heartland had the lowest levels of not working. Since 2000, this ordering has been stable. The not-working rate has been highest in the eastern heartland and lowest in the western heartland; the coasts are in between.

Figure 12 shows mortality rates between the three regions for prime age men. Between 1970 and the early 1980s, mortality fell smoothly for all three regions and the ordering was stable. The western heartland was the healthiest region of the country. During the early 1980s, male mortality rose on the coasts, partially reflecting the scourge of AIDS. Since the 1990s, the eastern heartland has been the outlier, with relatively high, and even occasionally rising, levels of mortality for prime age men. If we seek to understand the striking fact of rising prime age male mortality, as noted by Anne Case and Angus Deaton $(2015,2017)$, we need to look at the eastern heartland.

14. Online appendix figure 12 shows the division.

15. Online appendix figure 14 shows the cumulative growth by region based on a three-year pooled moving average. Online appendix figures 15 and 16 show the growth in per-worker GDP and employment. 


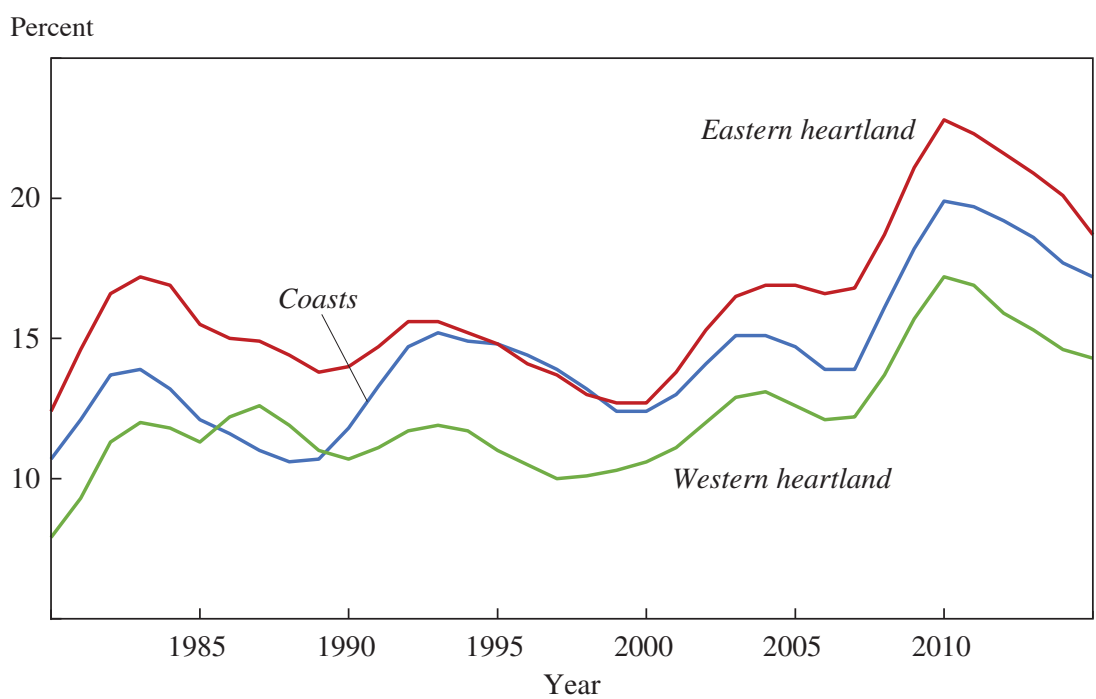

Sources: U.S. Census Bureau, Current Population Survey, Annual Social and Economic Supplement; IPUMS; authors' calculations.

a. The not-working rate is defined as the share of the population currently not employed. The series are three-year pooled moving averages. The sample includes civilian noninstitutionalized prime age men in the continental United States (excluding the District of Columbia).

Figure 12. Mortality Rates, $1970-2015^{\mathrm{a}}$

Deaths per 100 individuals

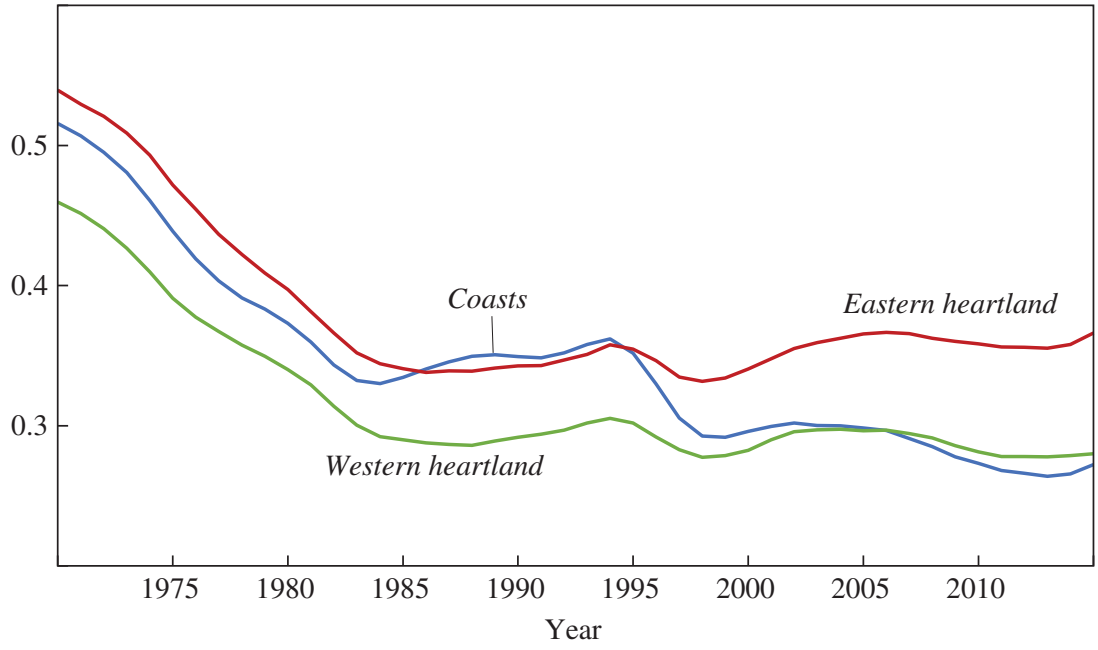

Sources: CDC WONDER; authors' calculations.

a. The mortality rate is defined as annual number of deaths from all causes per 100 individuals. The series are three-year moving averages. The sample includes prime age men in the continental United States (excluding the District of Columbia). 
Figure 13. Opioid Consumption, 2015

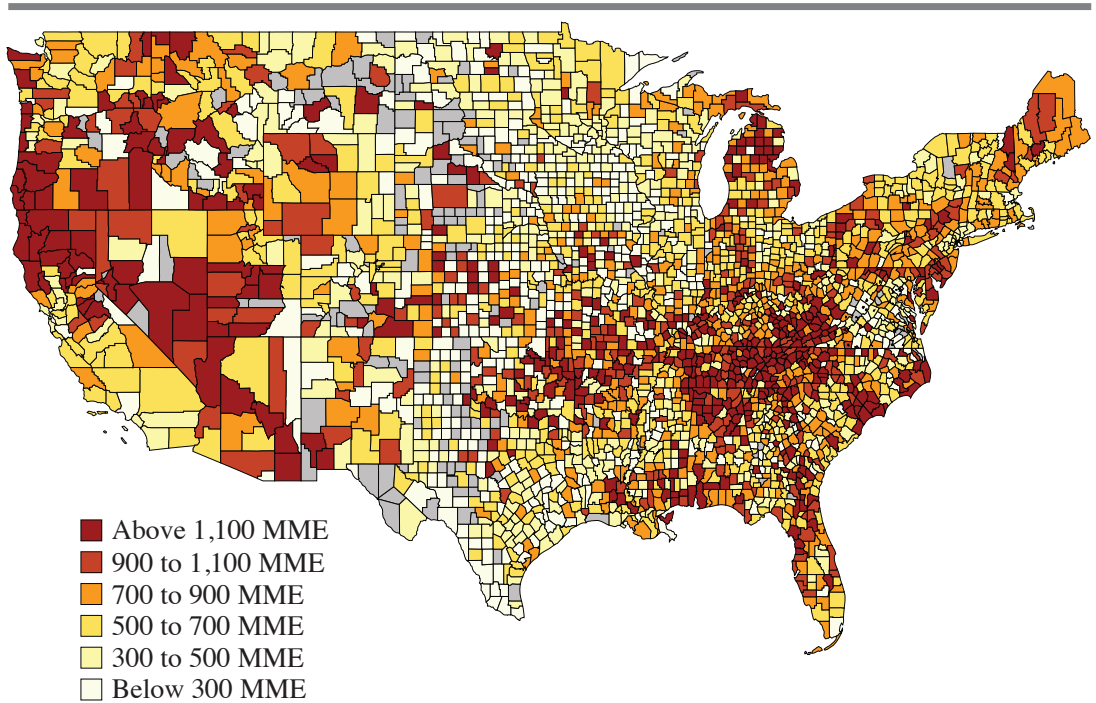

Sources: Centers for Disease Control and Prevention; Krueger (2017); authors' calculations.

a. The data are county-level opioid prescriptions per capita in morphine milligram equivalent (MME) units.

Figure 13 shows county-level opioid prescriptions per capita across the United States. These are particularly high in the low-employment areas of the eastern heartland.

A final social problem is imprisonment, which effects a significant share of the male population in many states. ${ }^{16}$ Until the mid-1990s, imprisonment rates were generally higher on the coasts than in the western heartland. Between the mid-1990s and 2010, the western heartland had the highest imprisonment rate. Now, both heartlands have imprisonment rates that are dramatically higher than the imprisonment rates on the coasts.

\section{I.E. Why Does the Nonemployment Rate Vary across the United States?}

Katharine Abraham and Melissa Kearney (2018) credit labor demandside factors (for example, competition with China and robots) with one-third

16. Online appendix figures 28 and 29 show the increase in incarceration rates. 
of the decline in the male employment rate since 1999. Supply-side factors account for less than one-tenth of the change, but much of the overall trend remains unexplained. At the national level, since 1999 wages at the bottom of the distribution (the 10th percentile) have been higher than they were in the 1970s, so it would seem that the rising rate of nonemployment must at least partially reflect shifting labor supply. ${ }^{17}$ Although perhaps not all of those not working could get a job paying $\$ 8.90$ per hour in 1999 , many surely could and chose not to work for such low earnings. Mark Aguiar and others (2017) suggest that the labor supply has shifted because of better entertainment options, but the willingness to work at low wages may have also fallen because of a more generous public and private safety net (for example, working spouses) or changing preferences.

However, nonemployment is a lower-tail phenomenon that may be more sensitive to the variance than to the mean of wage across space. If two separate regional markets experience a mean-preserving wage spread, then nonemployment in the low-wage market may rise dramatically while nonemployment in the high-wage area both starts and stays low. Even if the aggregate pattern shows constant wages and rising nonemployment, which is most compatible with a labor supply shift, regional patterns may be more compatible with shifting labor demand.

Figure 14 shows a -.39 correlation between changes in log median wages at the PUMA level and changes in the male nonemployment rate. Moreover, many of the PUMAs with sharply rising nonemployment rates have also experienced declining wages. Together, these facts suggest that labor demand shocks are playing a significant role in explaining the geography of joblessness.

What determines the spatial heterogeneity in labor demand? Deindustrialization has been a particularly adverse shock for less-skilled men, but that has been somewhat ameliorated in high-skilled areas, like Seattle, by reinvention based on knowledge-intensive industries. Consequently, the six regressions given in table 1 test whether area-level education and industrial history can explain the heterogeneity in joblessness. In regression 1, we find that 34 percent of the variation in male nonemployment rates across PUMAs in 2010 can be explained by two historical education variables: the share of the men without a high school diploma, and the share of men with

17. Although real hourly wages for the 10th percentile of the U.S. male income distribution were lower in the 1980s and 1990s than they had been in 1979, by 1999 hourly real wages had recovered. 
Figure 14. Changes in Not-Working Rates and Median Wage Growth, 1980-2010a

Change in the not-working rate, 1980-2010

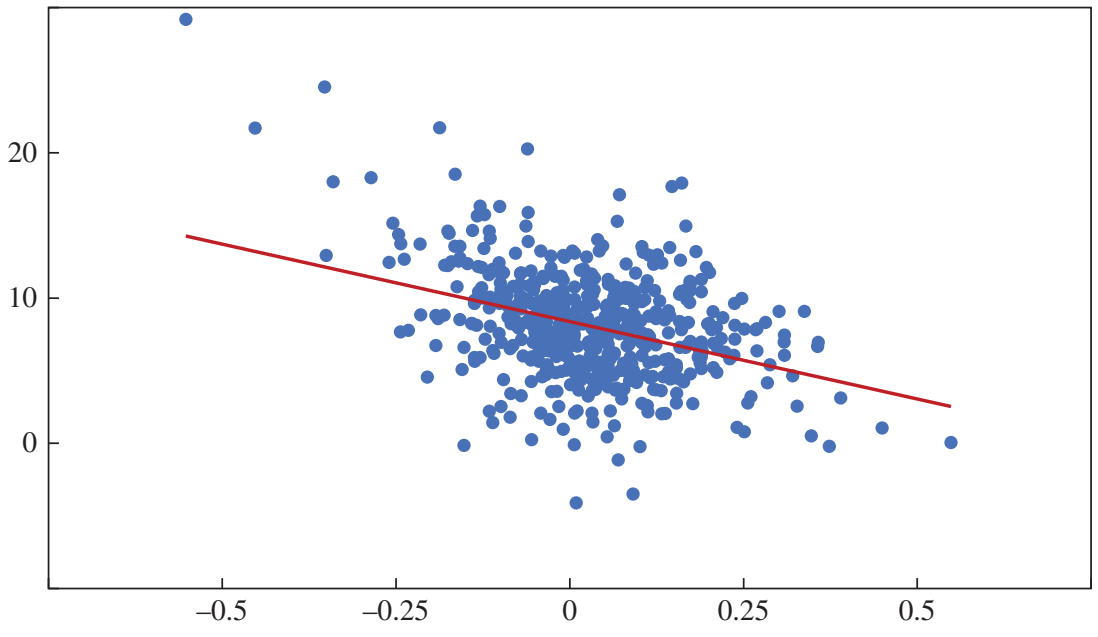

Change in log median wages, 1980-2010

Sources: U.S. Census Bureau, 1980 census, American Community Survey; IPUMS; authors' calculations.

a. The not-working rate is defined as the share of the population currently not employed. Median wages, expressed in 2016 dollars, are calculated using reported total wages for respondents who usually work more than 35 hours per week and who worked at least 50 weeks in the past year, excluding those reporting zero wages. Data for 1980 are from the 1980 census; data for 2010 are pooled 2009-11 data from the American Community Survey. The sample includes civilian noninstitutionalized prime age men in 1980-2000 consistent Public Use Microdata Areas in the continental United States (excluding the District of Columbia).

a college degree in 1980. This effect combines both the direct impact of education and any of the human capital externalities, as identified by James Rauch (1993) and Moretti (2004).

In regression 2, we include the share of prime age male workers in the PUMA in durable and nondurable manufacturing in 1980, and the $R^{2}$ rises to $.409 .{ }^{18} \mathrm{~A}$ history in durable manufacturing, which was particularly prevalent in the eastern heartland, predicts more nonemployment today. ${ }^{19}$ A history in nondurable manufacturing, which was more prevalent in the western heartland and the Southeast, predicts less nonemployment.

18. Online appendix figure 17 shows the share of manufacturing across the United States.

19. As Goldin and Katz (2008) document, industrial areas saw less reason to invest in education. 


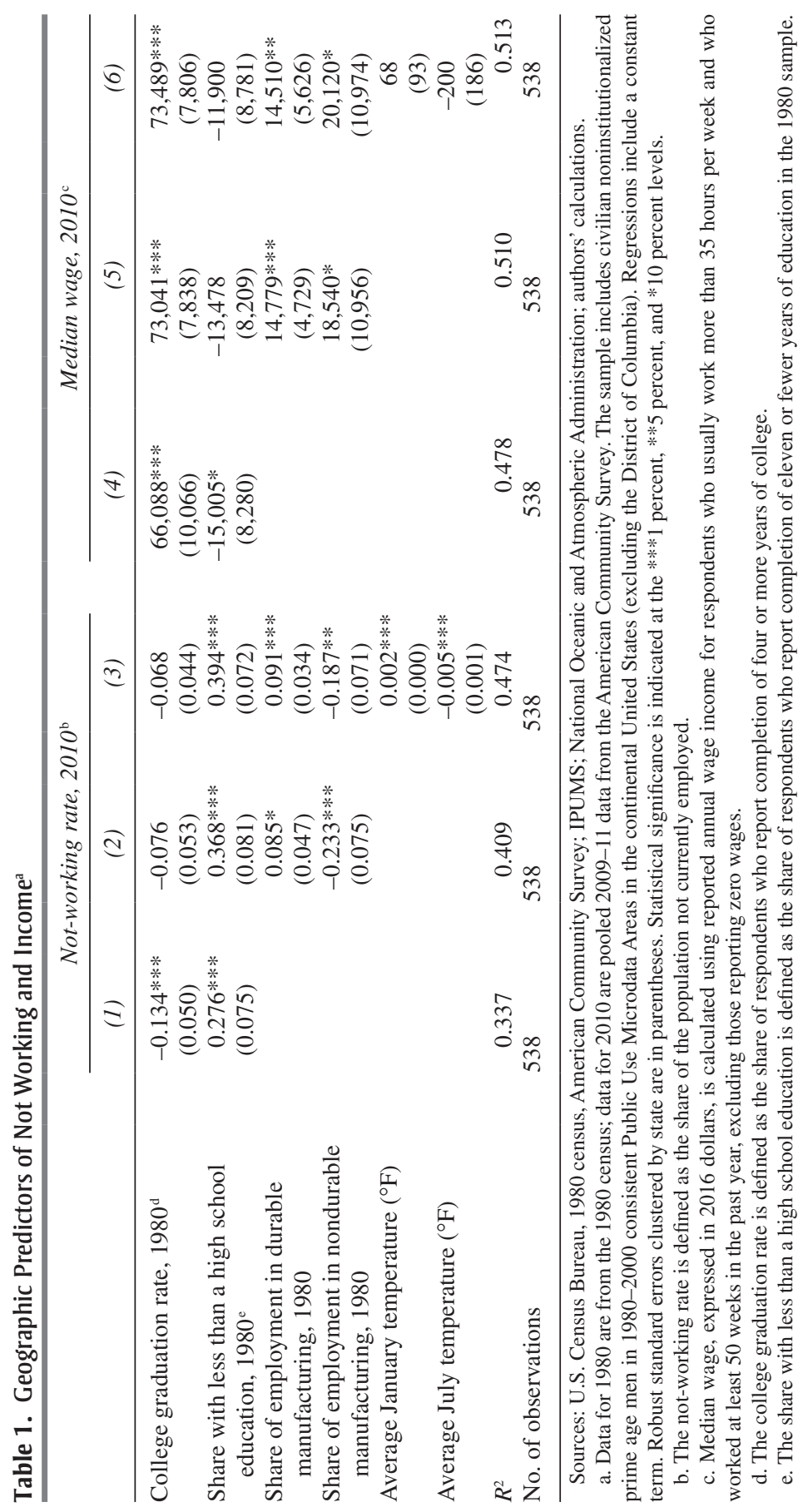


Regression 3 shows the impact of adding two state variables (January and July temperatures), which raise the $R^{2}$ to .474 . Higher January temperatures are associated with more nonemployment, while higher July temperatures are associated with less nonemployment (Boldin and Wright 2015).

The next three regressions in table 1 show the impact of the same variables on median wages. Almost universally, the same variables that are associated with higher median wages are also associated with lower not-working rates. The one prominent exception is durable goods manufacturing, which is associated with higher nonemployment rates and higher wages. One interpretation of this fact is that durable manufacturing industries developed the largest gap between wages paid to incumbent workers and the reservation wages of not-working outsiders.

Can state policies explain the differences in nonemployment across the United States? In the six regressions in table 2, we connect joblessness with three different state-level policy measures: corruption convictions, rightto-work laws (following Holmes 1998), and occupational licensing laws (which may capture local opposition to entrepreneurship). ${ }^{20}$ We do not use instruments, and we are well aware that few of our variables are truly exogenous. These regressions use individual-level data, with standard errors clustered at the state level.

Regression 1 shows the raw not-working rates between the three regions, controlling for nothing else. In regression 2, we control for individual education and historical area education, which wipes out the not-working gap between the eastern heartland and the coasts, but makes the gap between the western heartland and the coasts larger.

In regression 3, we also control for three state variables: corruption convictions, right-to-work laws, and the share of the population that has an occupational license. None of the variables has a statistically significant effect, and they do little to explain the differences between the western heartland and all other regions.

The final three regressions in table 2 repeat this analysis for 1980, 1990, and 2000. With historical perspective, the western heartland's gap looks unusually large. In 2000, both the eastern and western heartlands have lower not-working rates than the coasts, when we control for these characteristics. In 1980 and 1990, the regional differences look relatively small.

Individual and historical area education have persistent and strong negative effects on not working. From 1980 to 2000, the not-working rate was

20. Heterogeneity in these variables across states is shown in online appendix figures 30 , 31 , and 32 . 


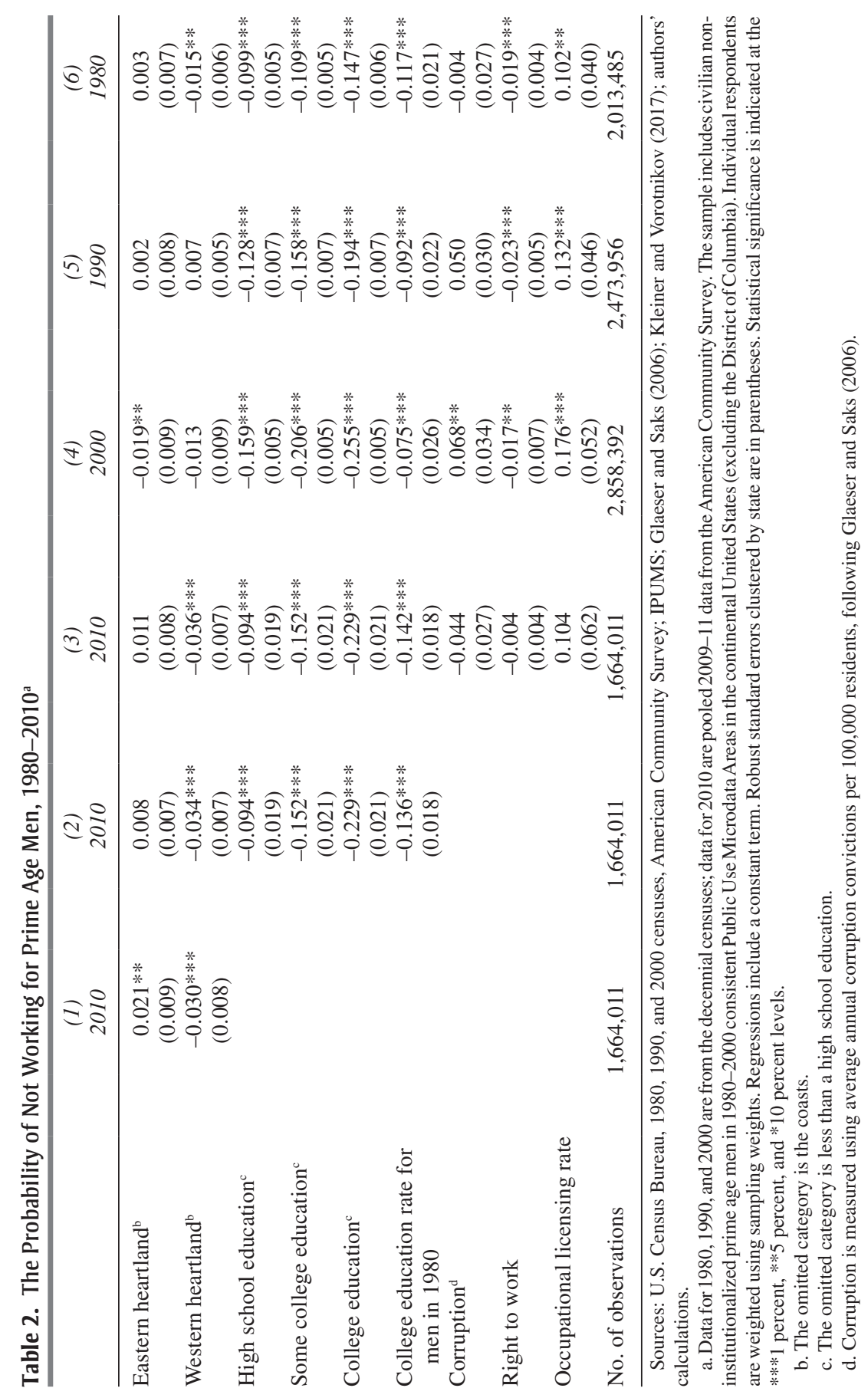


lower in right-to-work states. Corruption was positively associated with the not-working rate in 1990 and 2000. Occupational licensing has been positively associated with the not-working rate in every year.

The strong correlation between joblessness and education supports the common view that improved schooling is one way to address underperforming primary, secondary, and postsecondary schools in the American heartland. Community colleges are particularly natural institutions for delivering employment-related skills; and early childhood programs have been found to be particularly effective. We now discuss place-based, employment-oriented policies, which we see as a complement to, not a substitute for, education reform..$^{21}$

\section{The Economic Rationales for Place-Based Policies}

Standard locational externalities, including agglomeration economies and human capital externalities, imply that a decentralized spatial equilibrium may not be a Pareto optimum. But the large empirical literatures on such spatial spillovers provide little guidance about where these externalities are likely to be larger. Place-based policies can also insure against placebased shocks. Places may be useful tags for redistribution, which enable policymakers to rely less on effort-distorting, income-based redistribution. The largest weakness of equity and insurance justifications for place-based policies is that relatively little income variation occurs across, rather than within, states. Focusing on small geographies improves targeting, but also increases the downsides of place-based redistribution: capitalization of the benefits into housing costs and distorted migration.

The best case for place-based policies exists when spending in some areas generates a much bigger behavioral response than in other areas. If the supply of workers in the labor force is more elastic in some areas than in others, devoting more federal resources to that area will do more to reduce the not-working rate. When employment responses differ across space, welfare gains can be achieved, even without extra transfers to that area, by redirecting existing federal transfers. For example, reallocating Medicaid spending to employment subsidies may be welfare-improving in areas with a higher employment response to the effective wage.

21. Adult retraining for the displaced and nonemployed would also seem to be highly desirable, but the literature on such problems is decidedly mixed. 


\section{II.A. The Efficiency Rationale for Place-Based Redistribution}

The existence of agglomeration economies and congestion externalities means that local areas may have too many or too few people. To see this point, assume that there are only two regions in the economy, and assume that region 1 is the wealthier region..$^{22} \mathrm{~A}$ totally homogeneous national labor force $\left(N_{T}\right)$ is divided into the population of the two locales $\left(N_{j}\right.$ for $\left.j=1,2\right)$. Welfare in each region is a function of the population size, denoted $U_{j}\left(N_{j}\right)$.

A spatial equilibrium requires that utility levels are equalized between the two regions, so $U_{1}\left(N_{1}\right)=U_{2}\left(N_{2}\right)$. A social welfare planner who chooses populations to maximize aggregate welfare, $N_{1} U_{1}\left(N_{1}\right)+N_{2} U_{2}\left(N_{2}\right)$, would set $U_{1}\left(N_{1}\right)=U_{2}\left(N_{2}\right)+N_{2} U_{2}^{\prime}\left(N_{2}\right)-N_{1} U_{1}^{\prime}\left(N_{1}\right)$. The extra terms $N_{2} U_{2}^{\prime}\left(N_{2}\right)-N_{1} U_{1}^{\prime}\left(N_{1}\right)$ imply that the spatial equilibrium may not be a social optimum. Yet the fact that the competitive equilibrium is not socially optimal does not justify targeted regional policies if we do not know the direction of the problem. When we discuss the empirical research on agglomeration below, we will conclude that we have little confidence in our estimates of heterogeneity in agglomeration effects. Hence, agglomeration-based interventions seem as likely to harm as to help.

\section{II.B. The Insurance and Equity Rationale for Place-Based Redistribution}

The simplest equity-based justification for place-based policies is that a concave social welfare function implies benefits from insuring against local shocks, or even redistributing from high-income areas to low-income areas. Redistribution based on local income differences is less justifiable when higher income levels in some areas are offset by higher housing prices. A more straightforward argument for place-based redistribution is that it provides insurance against place-based shocks, without distorting the labor supply or work effort. ${ }^{23}$

The strongest argument against place-based redistribution is that the correlation between place and income is relatively weak in the United States. In a regression analysis where income is regressed on region dummies corresponding to our heartland definitions, these dummies explain only 0.2 percent of the variation in income. When income is regressed on state

22. We include a somewhat richer model in the online appendix.

23. Albouy (2010) makes a related point by emphasizing how standard progressive income taxation, without an explicit spatial dimension, distorts spatial decisions. Income taxes induce people to choose amenities and low housing costs rather than high incomes, although the distortionary impact of the income tax is diminished by the home mortgage interest deduction. 
dummies, these indicator variables explain only 1.1 percent of the variation. When income is regressed on PUMA dummies, these dummy variables explain 6.6 percent of the variation.

How big could the welfare gains be from spatial insurance across states and regions? To consider this question quantitatively, we assume that individuals just consume their income and that welfare is $y^{1-\gamma} / 1-\gamma$, and we focus on the case where $\gamma>1$. If income is log-normally distributed, then expected welfare is equivalent to $E(\ln y)-0.5(\gamma-1) V(\ln y) .^{24}$

In our data, the mean of log income for men is 10.55 . The mean standard deviation of $\log$ income within states is 1.14 , and that of income across states is 0.12 . Consequently, eliminating the variation in income across states would have only a small impact on welfare.

Eliminating spatial income variation would represent a real welfare gain, but it would also distort migration and capitalization. ${ }^{25}$ The tighter the geographic targeting, the larger the share of inequality that can be eliminated. Tighter geographic targeting will also ramp up the effects on migration and capitalization. Those distortions could be reduced if payments were based on birthplace, not place of current residence, but it is hard to imagine a birthplace-based national policy. The economic case for place-based insurance is theoretically strong; but in practice, the possible effect of such a policy seems limited and likely to have pernicious side effects.

\section{II.C. Differential Response Elasticities and Hot-Spots Policing}

We now turn to the third, and we think the best, rationale for spatial policy: market failures that can most plausibly be addressed at the local level. Police departments that use hot spots target their resources toward areas where there is more crime, presumably because the impact of these resources on crime is higher in these areas. This strategy seems to be effective on both targeted areas and neighboring areas, suggesting that

24. We can rewrite this as

$$
\frac{1}{1-\gamma} e^{\ln \left(y^{1-\gamma}\right)}=\frac{1}{1-\gamma} e^{-(\gamma-1) \ln (y)},
$$

and from this point, the standard constant absolute risk aversion calculations follow to derive a linear mean-variance frontier.

25. Distorting migration can itself be part of the benefit for residents of poorer areas, if out-migration reduces employment for the remaining residents, as shown by Greenwood and Hunt (1984). 
crime is not merely displaced to different areas (Braga, Papachristos, and Hureau 2014). We now turn to a model for place-based policies that captures the same economic logic-that resources can more effectively reduce the not-working rate when targeted toward areas with higher not-working rates.

We focus on public transfers to a population of less-skilled workers, who are on the margin of working. We assume that the United States is divided into $P$ regions, and that marginal workers' wages equal $w_{p}$ in region $p$. We assume that these workers never pay taxes, and that the social planner chooses lump sum transfers, conditional on working (denoted $e_{p}$ ) and not working (denoted $b_{p}$ ). The monetized private benefit of not working in place $p$ equals $d_{p}$. Wages and other benefits are independent of public transfers, and here we ignore mobility and housing markets. ${ }^{26}$

Individual $i$ 's welfare is $V$ (Earnings $)-I_{w} c_{i}$, where $I_{w}$ is an indicator function that takes on a value of 1 if the individual works; and $c_{i}$ is an idiosyncratic cost of working, where the cumulative density function $F_{p}\left(\hat{c}_{i}\right)$ denotes the share of the population in place $p$ that has the value of $c_{i}<\hat{c}_{i}$, and $f_{p}\left(\hat{c}_{i}\right)$ is the associated probability density function. Individuals will therefore work if and only if $V\left(w_{p}+e_{p}\right)-V\left(d_{p}+b_{p}\right) \geq c_{i}$, and we denote $c_{p}^{*}=V\left(w_{p}+e_{p}\right)-V\left(d_{p}+b_{p}\right)$. We first assume that the population level of each area is fixed.

The social welfare planner maximizes expected welfare across the population less the share of the population that is not working times a constant $k$, which captures any nonfiscal externalities from nonemployment. The government's cost of funds equals $\theta$, which can be interpreted as the Lagrange multiplier on the government's overall budget constraint. Within each area, $b_{p}$ and $e_{p}$ are chosen to maximize

$$
\begin{aligned}
& F_{p}\left(c_{p}^{*}\right)\left[V\left(w_{p}+e_{p}\right)-\theta e_{p}\right]-\int_{c_{i}=c_{\min }}^{c_{p}^{*}} c_{i} d F_{p}\left(c_{i}\right) \\
& +\left[1-F_{p}\left(c_{p}^{*}\right)\right]\left[V\left(d_{p}+b_{p}\right)-\theta\left(b_{p}+k\right)\right] .
\end{aligned}
$$

For proposition 1, we assume that $V(\cdot)$ is sufficiently concave to ensure that second-order conditions hold:

Proposition 1 . If $V^{\prime \prime}(\cdot)$ is sufficiently large in absolute value and $f_{p}^{\prime}\left(c_{p}^{*}\right)$ is sufficiently small, then both benefit levels are decreasing in both $w_{p}$ and $d_{p}$; an increase in $k$ causes $e_{p}$ to rise and $b_{p}$ to fall.

26. Some of these concerns are remedied in the online appendix. 
This proposition contains the core insurance motive for redistributing across space. Areas with lower wages should optimally receive both more benefits and a higher employment subsidy. The marginal utility of consumption for the working poor is higher in low-wage areas, and this raises the optimal employment subsidy. When the employment subsidy increases, it reduces the fiscal externality associated with nonemployment and consequently increases the optimal payment to those who do not work.

The first-order condition can also create a variant of the Baily-Chetty formula relating to the marginal utility of consumption for the employed and the jobless (Baily 1978; Chetty 2006):

$$
\frac{V^{\prime}\left(w_{p}+e_{p}\right)}{V^{\prime}\left(d_{p}+b_{p}\right)}=1-\frac{\varepsilon_{W}^{p}\left(b_{p}+k-e_{p}\right)}{w_{p}\left[1-F_{p}\left(c_{p}^{*}\right)\right]},
$$

where $\varepsilon_{w}^{p}=\left[f_{p}\left(c_{p}^{*}\right) V^{\prime}\left(w_{p}+e_{p}\right) w_{p}\right] /\left[F_{p}\left(c_{p}^{*}\right)\right]$ is the elasticity of the employment rate with respect to the wage, and $\left(b_{p}+k-e_{p}\right) / w_{p}$ reflects the size of the fiscal and nonfiscal externality associated with not working relative to the wage.

Equation 2 emphasizes the optimal heterogeneity in social policy across areas, not optimal redistribution across areas. The equation implies that in areas where the elasticity of employment with respect to the wage is higher, the employment subsidy should be higher relative to the payment for the jobless.

This can be interpreted as implying that even if the current U.S. benefits system for the not working were kept entirely in place, it would be optimal to increase support for the marginally employed in places where the employment response to wages is higher. Alternatively, the equation can be interpreted to mean that it would be optimal to shift benefits from the jobless to the marginally employed in states where employment is more responsive to the fiscal returns to working.

If $\varepsilon_{w}^{p}=0$, then consumption is equalized between the not working and the employed. If $\left(b_{p}+k-e_{p}\right) / w_{p}=0.2$, the not-working rate equals 0.2 , and $\varepsilon_{w}^{p}=0.25$, then $1-\varepsilon_{W}^{p}\left(b_{p}+k-e_{p}\right) / w_{p}\left[1-F_{p}\left(c_{p}^{*}\right)\right]=0.75$. If utility follows a constant relative risk aversion function of 0.5 , then the optimal consumption of the not working is 0.56 times that of the employed. A lower elasticity of labor response of 0.1 will imply higher levels of redistribution to the not working, so that the not working consume only 19 percent less than the employed.

These calculations suggest that small differences across space may generate large differences in the appropriate balance between employment 
subsidies and nonemployment benefits. In areas where the sensitivity of employment to wages is high, then subsidizing not working becomes particularly costly, when there are large externalities associated with nonemployment. In areas that are close to full employment, subsidizing the poor is less problematic. In the next two empirical subsections, we discuss the evidence related to both the size of the externality and differential employment responses by place.

\section{II.C. Mobility across Space}

The previous calculations ignored mobility, which would reduce the appeal of redistribution across space but might not change equation 2 . We can solve the social insurance problem in two steps: First, minimize expected social insurance payments in each location, holding expected utility fixed; and second, choose the combination of the levels of expected utility and expenditures across space to maximize aggregate social welfare, internalizing migration and capitalization effects. The procedure can be separated as long as only expected utility affects migrations, which will be true if we assume that migration decisions are made before an individual's value of $c_{i}$ is revealed.

Minimizing the costs of transfers and externalities $F_{p}\left(c_{p}^{*}\right) e_{p}+\left[1-F_{p}\left(c_{p}^{*}\right)\right]$ $\left(b_{p}+k\right)$, subject to a fixed utility constraint $F_{p}\left(c_{p}^{*}\right) V\left(w_{p}+e_{p}\right)-\int_{c_{i}=c_{\min }^{*}}^{c_{i}^{*}} c_{i} d F_{p}\left(c_{i}\right)$ $+\left[1-F_{p}\left(c_{p}^{*}\right) V\left(d_{p}+b_{p}\right)\right] \geq u_{p}$, is dual to the welfare maximization problem and also yields equation $2 .{ }^{27}$ Incorporating migration does have an effect on the overall level of welfare in each area; but it does not change the relationship between the marginal utility of consumption while working and not working. These results would, however, change if individuals observed their value of $c_{i}$ before migrating.

To formally model migration, we assume two locations and that people are endowed with a preference for the second location of $\varepsilon_{i}$, which is distributed according to a cumulative density function $G(\cdot)$ with probability density function $g(\cdot)$. We ignore housing and spatial externalities and denote total spending in region $p$ as $S_{p}$ and expected utility in each region as $U_{p}\left(S_{p}\right)$. The spatial equilibrium then defines a marginal migrant with a preference for location 2 of $\varepsilon^{*}$, which is defined so that $U_{1}\left(S_{1}\right)=U_{2}\left(S_{2}\right)+\varepsilon^{*}$, and the share of the population in location 1 equals $G\left(\varepsilon^{*}\right)$.

27. We are implicitly assuming that $k$ represents a national rather than a local externality. Results are not significantly changed if $k$ is treated as a local cost borne by potential migrants. 
If the social planner's cost of funds is again $\theta$, the overall maximization problem can be written as

$$
G\left(\varepsilon^{*}\right)\left[U_{1}\left(S_{1}\right)-\theta S_{1}\right]+\left[1-G\left(\varepsilon^{*}\right)\right]\left[U_{2}\left(S_{2}\right)-\theta S_{2}\right]+\int_{\varepsilon \geq \varepsilon^{*}} \varepsilon d G(\varepsilon)
$$

This leads to two first-order conditions that can be combined to generate

$$
\frac{U_{1}^{\prime}\left(S_{1}\right)}{U_{2}^{\prime}\left(S_{2}\right)}=1-\frac{\varepsilon_{N 1}^{S}\left(S_{2}-S_{1}\right)}{S_{1}\left[1-G\left(\varepsilon^{*}\right)\right]},
$$

where $\varepsilon_{N 1}^{s}$ reflects the elasticity of mobility into area 1 with respect to area 1 subsidies, or $\varepsilon_{N I}^{s}=U_{1}^{\prime}\left(S_{1}\right) S_{1} g\left(\varepsilon^{*}\right) / G\left(\varepsilon^{*}\right)$. Equation 2 then describes the structure of payments within an area, whereas equation 4 describes the structure of payments across an area.

If $\varepsilon_{N I}^{s}=0$ and there is no mobility response, then optimal policies equalize the marginal utility of spending across areas. If mobility is perfectly elastic, so that $\varepsilon_{N I}^{s}$ goes to infinity, then spending must be equalized across areas. For intermediate levels of mobility, there will be more spending on the area with a higher marginal utility of spending: $S_{2}>S_{1}$ if and only if $U_{2}^{\prime}\left(S_{2}\right)>U_{1}^{\prime}\left(S_{1}\right)$. This equation somewhat supports our previous discussion suggesting that redistribution across space is more likely to enhance welfare when migration is more limited.

But the larger point of this subsection is that concerns about capitalization and migration influence the expected welfare for residents of a specific area, but not the optimal ratio of marginal utility levels for the employed and the not working. If the elasticity of the not-working rate with respect to wages is higher in one place, then that place should do more to make work pay.

A final justification for targeting related to "hot spots" is that the macroeconomic costs of supporting not working might be lower if we target West Virginia more than San Francisco. Phillips curve-type reasoning suggests that reductions in unemployment might increase pressure for wage-led inflation. This threat seems larger if San Francisco's not-working rate is being pushed from 5 percent to 2 percent than if West Virginia's not-working rate is being pushed from 13 percent to 10 percent.

\section{II.D. The Downsides of Spatial Policy: Capitalization, Mobility, and Cost}

As the previous discussion emphasized, two of the major downsides of place-based strategies are capitalization and distorted locational choice. 
If a place-based policy makes an area more attractive to a group, then that group will move into the area or bid up prices, or both, depending on the elasticity of the housing supply. The policy will have more of an impact on prices when the supply of space is inelastic. The policy will distort location more when the supply of space is elastic; but even when space is inelastic, there still can be a distortionary effect on the composition of the population.

A third major downside of spatial policy is cost, which in turn is a function of the targeting of the policy. In all three discussions, we assumed that subsidies and taxes are not well targeted within the region. A general employment subsidy has these features, as would policies that increase general labor demand in the poor region through the use of tax credits or direct government spending. Yet it is possible to imagine policies that are more directly targeted toward marginal workers. Those policies would reduce the taxes needed to encourage employment and would also dampen capitalization and migration effects, because they have an impact on a smaller share of the population.

The three motives for place-based strategies have different implications for the costs of capitalization and distorted mobility. If the point of spatial targeting is to achieve agglomeration-related benefits, then distorted locational choice is not a problem but a desired outcome. The point of the policy is to induce economic activity to relocate. Capitalization might be a slight negative, in that the property owners will reap many of the benefits, but that would not particularly undo the efficiency gains from relocation.

If the purpose of spatial targeting is to redistribute toward poorer residents, then relocation is not intrinsically desirable. Yet if we cannot determine the sign of the impact of relocating people and firms on aggregate efficiency, then we also cannot be sure whether inadvertent relocation generates welfare losses or benefits. A prominent exception to this claim is that there may be considerable downsides from concentrating poverty and nonemployment, particularly because this may cause welfare losses to the poor that undo any benefits that come from targeting resources toward a particular area.

Capitalization, by contrast, will tend to work against the redistributive benefits of targeting resources toward poorer areas. If the primary beneficiaries of these benefits are property owners, then the policy may be progressive across places but regressive within places. Once again, targeting can reduce the capitalization-related downsides of any policy.

If the goal is targeting resources against a demonstrable social problem, like nonemployment, then efficiency, not equity, is again the main objective. In this case, the redistribution to owners due to capitalization is not 
particularly problematic; nor are distorted locational choices. Even more broadly, the policy can be a place-based benefit shift, which fights nonemployment without inducing in-migration. We now discuss the two parameters that are needed to use equation 2, our modified Baily-Chetty formula.

\section{Do Employment Elasticities Differ across Place?}

The theoretical case for the spatial targeting of employment subsidies depends on whether such policies have a greater marginal impact on employment in some areas. Employment subsidies could have a larger impact in distressed areas, but the opposite is also possible. Areas with high not-working rates might have social problems that lead even fewer people to be on the margin of working. Areas with high not-working rates might have extremely inelastic labor demand, so that few new jobs will be created because of a subsidy. The case for infrastructure, relative to subsidies, is stronger when private labor demand is inelastic. It is an empirical question as to whether interventions in high-poverty areas are more likely to increase the level of employment. ${ }^{28}$

We have three ways of testing for differential employment elasticities. First, and most obviously, we can look at the impact of labor demand shocks on the not-working rate and test for heterogeneity across space. Second, we can review the surprisingly limited body of literature on heterogeneous spatial effects of social programs on the not-working rate. And third, we can revisit the evidence presented by Nakamura and Steinsson (2014) linking government spending to GDP growth and test for heterogeneous treatment effects on the not-working rate.

\section{III.A. The Heterogeneous Impact of Labor Demand Shocks}

We first look at the impact of labor demand shocks on the not-working rate. We use a Bartik demand shock (following Bartik 1991), interacting initial industry shares with changes in national employment in the industry outside the PUMA or state, or

$$
\text { Bartik shock }=\sum_{\text {industries }}\left(\frac{e m p_{i, s, t_{0}}}{e m p_{s, t_{0}}}\right)\left(\frac{e m p_{i, t+1}^{U S \text { nots }}-e m p_{i, t}^{U S \text { nots }}}{e m p_{i, t}^{U S \text { not } s}}\right),
$$

28. Our discussion of this question builds on the work of Bartik (2015), who finds some evidence that local demand shocks have a greater impact in areas with higher initial unemployment rates. A large number of previous studies have also examined the persistence of local labor demand shocks, with varying conclusions. 
where $e m p_{i, s, t_{0}}$ is employment in industry $i$, location $s$, and initial time $t_{0}$; $e m p_{s, t_{0}}$ is total employment in location $s$ at initial time $t_{0}$; and $e m p_{i, t}^{U S \text { nots }}$ is the employment in industry $i$ at time $t$ in the United States outside location $s$. Thus, this shock represents the percentage growth in employment in the location that would have been predicted if the location's industries saw their employment grow at the national average rate.

We look at Bartik shocks at both the PUMA and state levels. We begin with state-level estimates over the 1977-2016 period. Regressions 1 and 2 in table 3 show the negative impact of the Bartik shock over the entire period, as expected, and that this impact is larger in states with higher initial not-working rates. Regressions 3 and 4 show that this interaction term is robust to the addition of year fixed effects. It does seem as if demand shocks are more strongly associated with changes in the not-working rate in places with higher average not-working rates.

Regressions 5 and 6 show results for housing prices. The state-level housing price index is a repeat sales index prepared by the Federal Housing Finance Agency. Regression 5 finds that positive Bartik shocks are associated with more housing price growth, suggesting that economic success is associated with higher housing costs; but the coefficient is not statistically significant. Regression 6 shows a strong positive correlation between the not-working rate and the Bartik shock. The Bartik shock has a statistically significant impact on not-working rates in states with high historical notworking rates relative to other states, but this interaction is not statistically significant for housing prices.

Regressions 7 and 8 show results at the substate level using consistent PUMAs and annual changes since 2005, because of limited data availability before that period. Regression 7 shows that the Bartik shock has a strong negative impact on the not-working rate over this period. And regression 8 shows that this effect is far more strongly concentrated in places that had high levels of not-working rates in 2005. A change of 10 percentage points in the not-working rate increases the impact of the Bartik shock by almost 50 percent relative to a zero benchmark for the not-working rate.

Finally, we examine the impact of trade shocks on prime age male nonemployment, using shocks identified by Autor, Dorn, and Hanson (2013). They use the change in Chinese import exposure per worker in a region as their main measure of local labor market exposure to import competition. To address potential endogeneity issues, they instrument growth in U.S. imports with growth in Chinese imports in eight other developed economies. In table 4, we follow their approach and regress the share of 


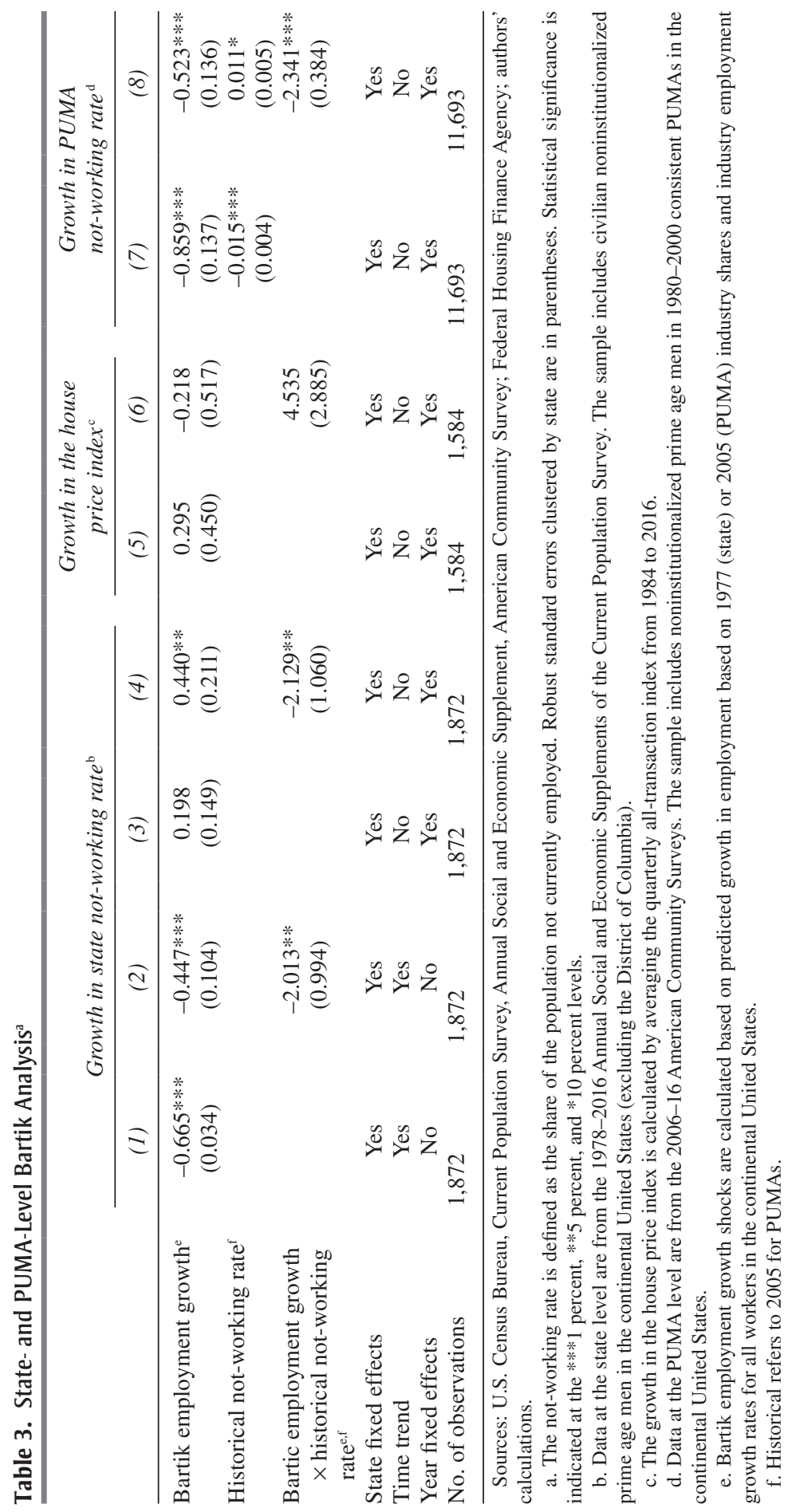


Table 4. The Impact of Chinese Import Shocks on Not Working, 1990-2007a

\begin{tabular}{|c|c|c|c|c|}
\hline & \multicolumn{2}{|c|}{ Change in not-working rate } & \multicolumn{2}{|c|}{$\begin{array}{l}\text { Change in long-term } \\
\text { not-working rate }\end{array}$} \\
\hline & (1) & (2) & (3) & (4) \\
\hline $\begin{array}{l}\text { Change in trade } \\
\text { exposure }\end{array}$ & $\begin{array}{l}0.831 * * * \\
(0.172)\end{array}$ & & $\begin{array}{l}0.372 * * * \\
(0.093)\end{array}$ & \\
\hline $\begin{array}{l}\text { Change in trade } \\
\text { exposure, baseline } \\
\text { zones, } \beta_{l}\end{array}$ & & $\begin{array}{l}0.823 * * * \\
(0.173)\end{array}$ & & $\begin{array}{l}0.368 * * * \\
(0.094)\end{array}$ \\
\hline $\begin{array}{l}\text { Change in trade } \\
\text { exposure, high } \\
\text { not-working rate } \\
\text { zones, } \beta_{h}-\beta_{l}^{\mathrm{c}}\end{array}$ & & $\begin{array}{r}0.597 * \\
(0.318)\end{array}$ & & $\begin{array}{c}0.339^{*} \\
(0.191)\end{array}$ \\
\hline $\begin{array}{l}\text { Percentage of total } \\
\text { employment in } \\
\text { manufacturing, } t-1\end{array}$ & $\begin{array}{l}-0.068 * * \\
(0.028)\end{array}$ & $\begin{array}{l}-0.066^{* *} \\
(0.028)\end{array}$ & $\begin{array}{l}-0.015 \\
(0.014)\end{array}$ & $\begin{array}{l}-0.013 \\
(0.014)\end{array}$ \\
\hline $\begin{array}{l}\text { Percentage of } \\
\text { population that } \\
\text { is college educated, } \\
t-1\end{array}$ & $\begin{array}{l}-0.031 \\
(0.030)\end{array}$ & $\begin{array}{c}-0.027 \\
(0.029)\end{array}$ & $\begin{array}{l}-0.010 \\
(0.014)\end{array}$ & $\begin{array}{l}-0.007 \\
(0.014)\end{array}$ \\
\hline $\begin{array}{l}\text { Percentage of } \\
\text { population that is } \\
\text { foreign born, } t-1\end{array}$ & $\begin{array}{l}-0.108 * * * \\
(0.024)\end{array}$ & $\begin{array}{l}-0.106 * * * \\
(0.024)\end{array}$ & $\begin{array}{l}-0.051 * * * \\
(0.011)\end{array}$ & $\begin{array}{l}-0.050 * * * \\
(0.011)\end{array}$ \\
\hline $\begin{array}{l}\text { Percentage of total } \\
\text { employment that is } \\
\text { female, } t-1\end{array}$ & $\begin{array}{l}0.191 * * \\
(0.090)\end{array}$ & $\begin{array}{l}0.199 * * \\
(0.092)\end{array}$ & $\begin{array}{c}0.002 \\
(0.030)\end{array}$ & $\begin{array}{c}0.006 \\
(0.031)\end{array}$ \\
\hline $\begin{array}{l}\text { Percentage of total } \\
\text { employment in } \\
\text { routine occupations, } \\
t-1\end{array}$ & $\begin{array}{l}0.217 * * \\
(0.095)\end{array}$ & $\begin{array}{l}0.226 * * \\
(0.094)\end{array}$ & $\begin{array}{c}0.044 \\
(0.050)\end{array}$ & $\begin{array}{c}0.049 \\
(0.050)\end{array}$ \\
\hline $\begin{array}{l}\text { Average offshorability } \\
\text { index of occupations, } \\
t-1\end{array}$ & $\begin{array}{c}-1.142 * \\
(0.660)\end{array}$ & $\begin{array}{c}-1.204^{*} \\
(0.661)\end{array}$ & $\begin{array}{l}-0.187 \\
(0.270)\end{array}$ & $\begin{array}{l}-0.222 \\
(0.270)\end{array}$ \\
\hline $\begin{array}{l}\text { Census region fixed } \\
\text { effects }\end{array}$ & Yes & Yes & Yes & Yes \\
\hline Period fixed effects & Yes & Yes & Yes & Yes \\
\hline No. of observations & 1,444 & 1,444 & 1,444 & 1,444 \\
\hline
\end{tabular}

Sources: U.S. Census Bureau, 1990 and 2000 censuses, American Community Survey; IPUMS; Autor, Dorn, and Hanson (2013); authors' calculations.

a. The not-working rate is defined as the share of the population not currently employed. Data for 1990 and 2000 are from the decennial censuses; data for 2007 are pooled 2006-08 data from the American Community Survey. The sample includes noninstitutionalized prime age men. Regressions are weighted as by Autor, Dorn, and Hanson (2013). Robust standard errors clustered by state are in parentheses. The change in trade exposure and controls at the commuting zone level are for the entire working population. Statistical significance is indicated at the ***1 percent, $* * 5$ percent, and $* 10$ percent levels. b. Long term is defined as more than 12 months.

c. Zones with high not-working rates are in the top 10 percent of the distribution of not-working rates for prime age men in 1990. 
not-working men or long-term not-working men on the change in Chinese imports per worker.

In regression 1, we examine the effect of a shock in Chinese imports on prime age male not-working rates. As expected, increases in Chinese import exposure are associated with an increase in the level of prime age male nonemployment, and the coefficients are statistically significant. Regression 2 examines the heterogeneity of responsiveness based on initial not-working rates in 1990. We find that commuting zones with the highest levels of initial not-working rates, defined as being in the top 10 percent, experience a higher level of nonemployment in response to changes in Chinese import exposure. Regressions 3 and 4 report the same results for long-term notworking rates, and we find a similar pattern, albeit with smaller absolute increases. $^{29}$

These results may be relatively unsurprising. A shock to local labor demand has more impact on the not-working rate in places where nonemployment is high than in places that are already near full employment. Yet this heterogeneity is crucial in justifying spatially heterogeneous policies that encourage employment more in some areas than in others.

\section{III.B. Heterogeneous Responses to Past Social Programs}

There has been surprisingly limited research testing whether national changes in policy have heterogeneous treatment effects across space. For example, a large body of literature (Meyer and Rosenbaum 2001; Eissa and Liebman 1996) has examined the impact of the Earned Income Tax Credit (EITC) on employment. But we have found that none of these studies ask whether the impact of the credit was higher in places that had initially higher levels of nonemployment. David Neumark and William Wascher (2011) find interactions between the EITC and state minimum wages, but the imperfect relationship between the minimum wage and nonemployment makes these results hard to interpret.

There is abundant evidence suggesting that targeted social programs can have a large impact on the not-working rate. For example, Cynthia Miller and others (2017) test an EITC-like product, called Paycheck Plus,

29. These results are merely suggestive of the importance of regional heterogeneity. The size and statistical significance of heterogeneity is dependent on the exact form chosen. We have focused on the interaction of shocks with the initial not-working rate, but other state characteristics may also be important. 
that is targeted toward people without children. The treatment effect of this product on employment outcomes, especially on filing taxes, is higher for people who initially earned less than $\$ 10,000$ per year. We hope that future research will test more regularly for whether social interventions have more impact in some states than in others.

\section{III.C. Spatial Heterogeneity as Identified by Nakamura and Steinsson}

In this subsection, we use the shocks to federal spending that are identified by Nakamura and Steinsson (2014). ${ }^{30}$ We focus on state-level, prime age male not-working rates as our outcome of interest, and we test for interactions between these shocks and average not-working rates within states. Nakamura and Steinsson's approach is to regress the percentage change in the employment rate within the state on the change in military spending over the same period. They instrument for the change in military spending by interacting the change in national military spending with a state dummy.

Our specification is to follow Nakamura and Steinsson (2014) and thus to regress

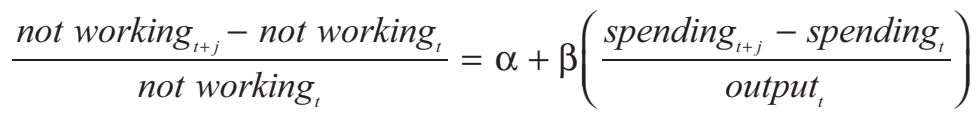

$$
\begin{aligned}
& +\delta_{t}+\gamma_{t}+\varepsilon_{t},
\end{aligned}
$$

where not working ${ }_{t}$ refers to the not-working rate in the state, spending ${ }_{t}$ refers to per capita military procurement spending, output $t_{t}$ refers to per capita output, and $\delta_{t}$ and $\gamma_{t}$ are time and year fixed effects. We instrument for the spending variable using the percentage growth in national military spending interacted with a state dummy. This specification follows the structure of Nakamura and Steinsson's employment rate regressions.

We do this for one-, two-, and three-year changes. Our primary focus is on the interaction between military spending and the average not-working rate in the state. We implement this by generating an interaction between

30. A number of other studies have examined the heterogeneous impact of government expenditures at the local level. For example, see Dube, Kaplan, and Zipperer (2015). A general review of local multipliers is provided by Chodorow-Reich (2017). 
the spending variable and an indicator variable that takes on a value of 1 if the state is among the 25 percent of states with the highest not-working rate during the entire period. This is a conceptually different experiment from Nakamura and Steinsson's (2014) interaction between military spending and whether the state has a high not-working rate relative to its historic norm.

We show the results for the one-year change in the not-working rate in regressions 1 and 2 in table 5. Regression 1 confirms that the basic result holds for the not-working rate: An increase in military spending equal to 1 percent of output is associated with a 6.2 percent decrease in the not-working rate, although the coefficient is not statistically significant. Regression 2 shows that the coefficient on military spending is significantly larger in areas with high not-working rates and is statistically significantly different from areas with low not-working rates.

In regressions 3 and 4, we look at the two-year change in the not-working rate, which is Nakamura and Steinsson's (2014) preferred specification. The overall effect on the not-working rate is significant at the 10 percent level. An increase in military spending equal to 1 percent of output is associated with a 6.4 percent decrease in the not-working rate. The interaction with high not-working rates is small and insignificant.

In regressions 5 and 6 , we look at the three-year change in the notworking rate. In this case, an increase in military spending equal to 1 percent of output is associated with a 9.6 percent decrease in the notworking rate and is statistically significant at the 5 percent level. The interaction is negative and economically meaningful in size, but it is so imprecise that we can draw little confidence from this result. Overall, these results, especially for the one-year change, suggest that military spending might be more effective in areas with high not-working rates, but they are no more than suggestive.

\section{The Externalities of Not Working}

If joblessness generates no externalities, then there is no reason for the government to promote employment in our model. There may still be a redistributive or insurance motive for spatial policy, but there would be little reason to focus particularly on joblessness. In this section, we discuss the three types of externalities associated with nonemployment: pure fiscal losses from reduced taxes and increased social spending; social spillovers borne by family and friends; and not-working spillovers, where one individual who is not working increases the chance that others will not work. 


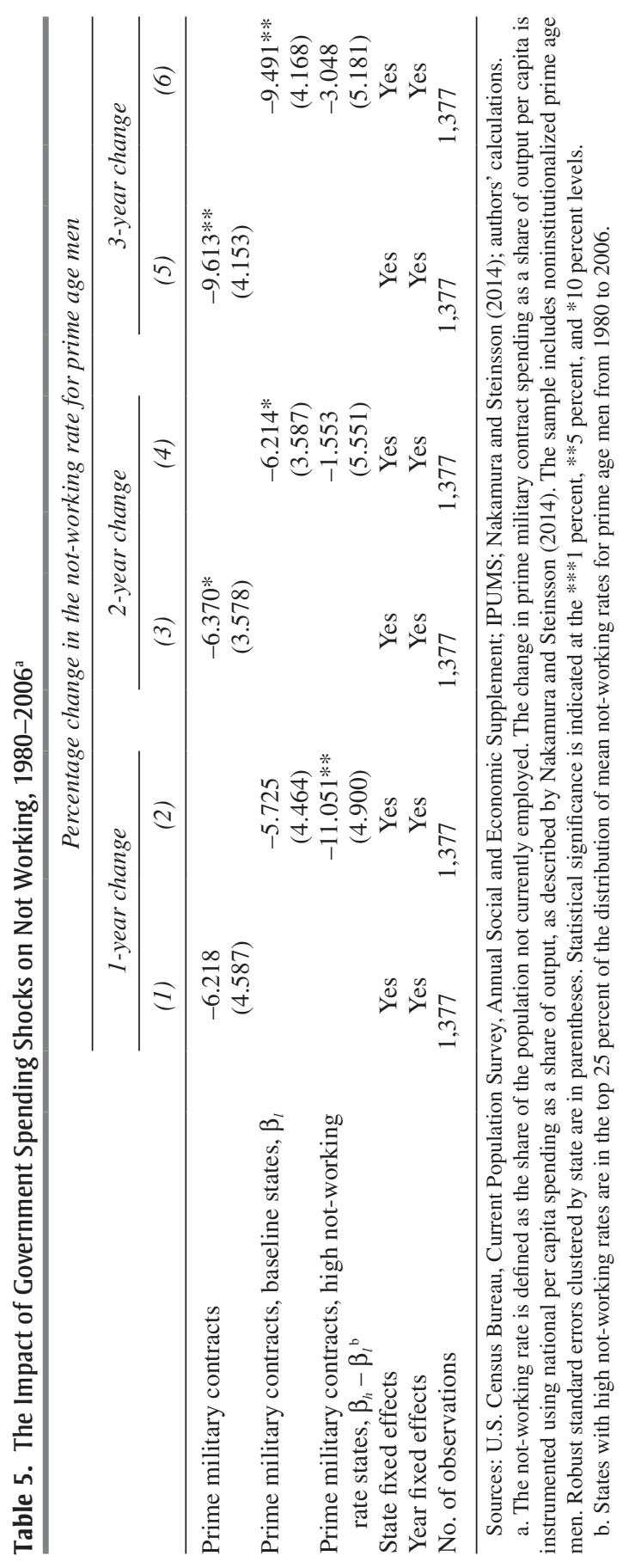


We do not consider externalities that could work through congestion of the employment-matching process, basically because we consider congestion to be a short-run phenomenon, while we are primarily interested in the long-run costs of concentrated nonemployment.

\section{IV.A. Fiscal Externalities: Taxes and Spending}

The most obvious externality associated with nonemployment is the cost borne by other taxpayers due to a reduction in tax revenue and an increase in public expenditures. We first focus on the income of notworking prime age men, to understand the amount of public resources they are receiving.

Table 6 shows income sources for four groups: all employed prime age men; low-income employed prime age men, who are defined as having annual family earnings below $\$ 40,000$; prime age men who have not been working for less than 12 months; and prime age men who have not been working for more than 12 months. The data are averaged over the 2010-16 period and are based on the ASEC.

The missing earnings of the not working are supplemented mainly by disability payments and by the other residents of their own home. The added public expenditure going to the short-term not working relative to low-income workers is $\$ 2,300$; the average added expenditure going to the long-term not working is $\$ 6,300$. Averaged over the entire not-working population, the increase is $\$ 4,900$, which is 26 percent of low-income individual wages in this sample.

In table 7, we break out the earnings of the long-term not working by region. The results are quite similar. The family incomes in the heartland areas are lower than in the coastal states. Disability payments are higher in the eastern heartland than in the other regions. Nowhere are family transfers a large share of total earnings.

Because disability is such an important part of public support for notworking men, we now focus on the geography and time series of disability in the United States. Figure 15 shows disability rates across the United States. We see the familiar pattern of suffering in the eastern heartland, but higher rates of being on disability certainly do not seem to generate higher earnings for the not working.

Should disability be seen as a transfer to the not working that would stop if employment increased, or a social insurance program that compensates the unlucky who receive negative health shocks and could not work in any case? Many of the not working report regular health problems. Figure 16 shows that approximately 30 percent of the not working in all 


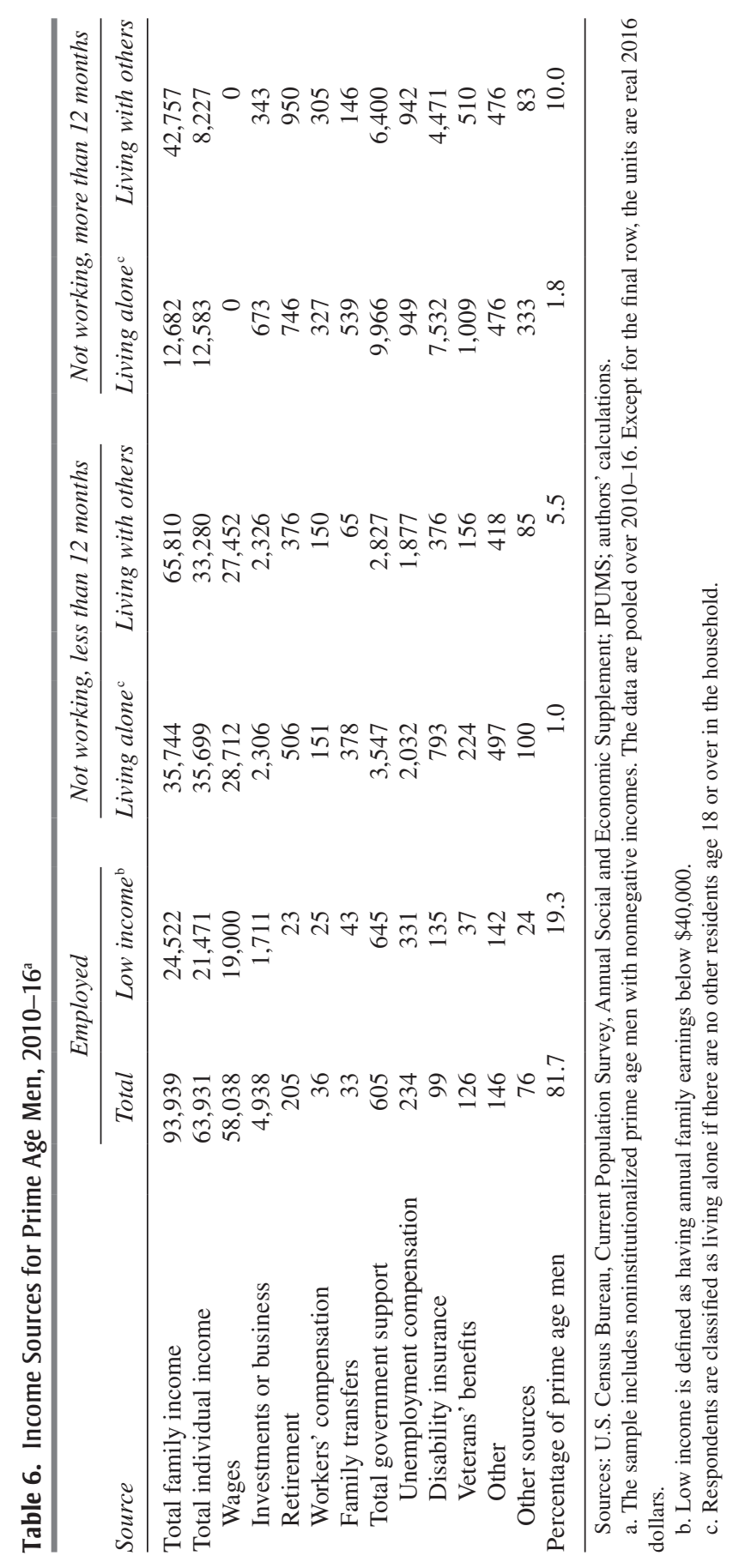


Table 7. Income Sources for Long-Term Not-Working Prime Age Men, 2010-16a

\begin{tabular}{lrrr}
\hline Source & Coasts & Eastern heartland & Western heartland \\
\hline Total family income & 40,318 & 34,859 & 36,897 \\
Total individual income & 8,665 & 9,283 & 8,964 \\
Wages & 0 & 0 & 0 \\
Investments or business & 400 & 275 & 541 \\
Retirement & 890 & 850 & 1,089 \\
Workers' compensation & 358 & 254 & 244 \\
Family transfers & 211 & 145 & 279 \\
Total government support & 6,652 & 7,688 & 6,711 \\
$\quad$ Unemployment compensation & 1,072 & 756 & 862 \\
$\quad$ Disability insurance & 4,584 & 5,834 & 4,661 \\
$\quad$ Veterans' benefits & 499 & 638 & 751 \\
$\quad$ Other & 498 & 461 & 438 \\
Other sources & 154 & 69 & 100 \\
\hline
\end{tabular}

Sources: U.S. Census Bureau, Current Population Survey, Annual Social and Economic Supplement; IPUMS; authors' calculations.

a. The sample includes civilian noninstitutionalized prime age men with nonnegative incomes in the continental United States (excluding the District of Columbia). Long term is defined as more than 12 months. The data are pooled over 2010-16. The units are real 2016 dollars

Figure 15. Disability Rates, $2015^{a}$

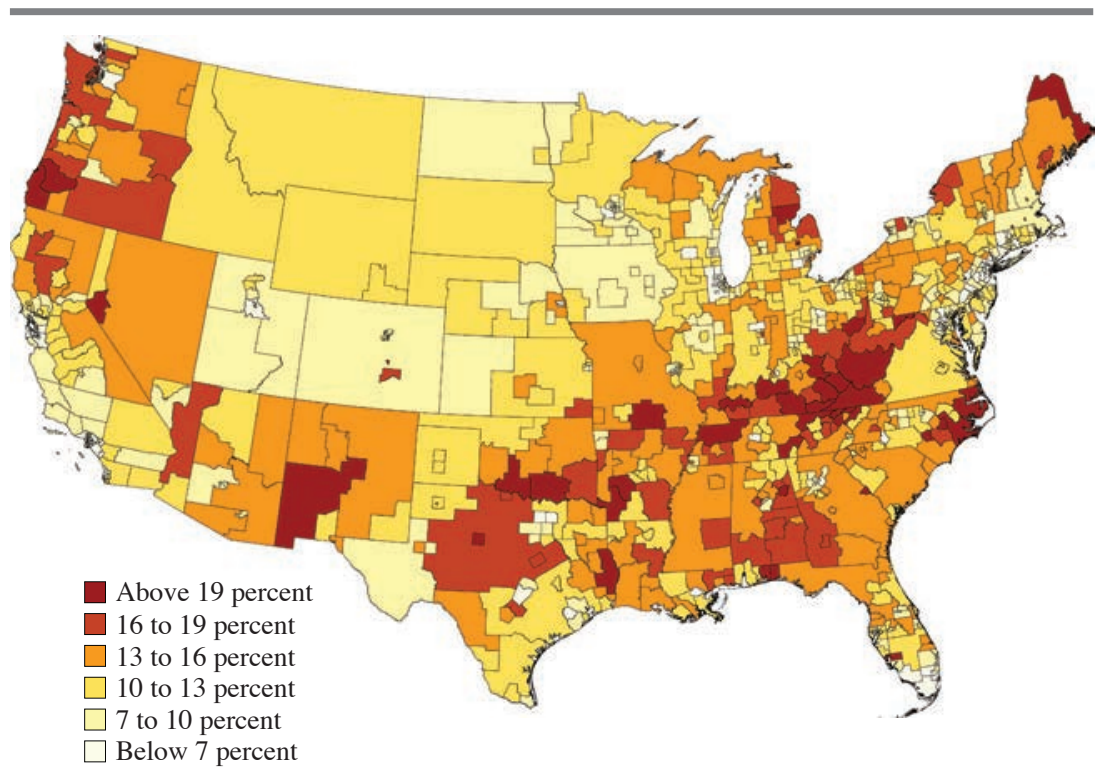

Sources: U.S. Census Bureau, American Community Survey; IPUMS; authors' calculations.

a. The disability rate is the share of respondents who report having a disability in any category. The data are pooled over 2014-16. The sample includes civilian noninstitutionalized prime age men in 2000-10 consistent Public Use Microdata Areas in the continental United States. 
Figure 16. The Prevalence of Physical Health Problems, 2011-16a

Percent

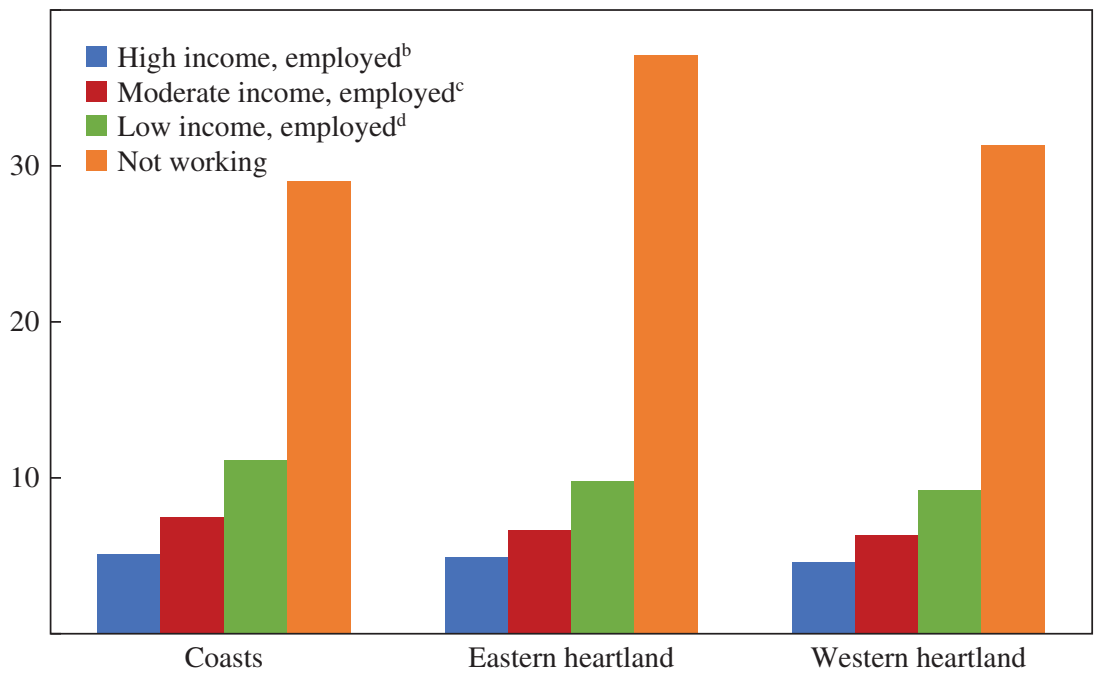

Sources: U.S. Centers for Disease Control and Prevention, Behavioral Risk Factor Surveillance System; authors' calculations.

a. This figure shows the share of respondents who report physical health was not good on at least 10 days in a month. The data are pooled over 2011-16. The sample includes civilian noninstitutionalized prime age men in the continental United States (excluding the District of Columbia).

b. High income is defined as household income of more than $\$ 50,000$ per year.

c. Moderate income is defined as household income between $\$ 35,000$ and $\$ 50,000$ per year.

d. Low income is defined as household income of less than $\$ 35,000$ per year.

three regions report 10 or more days of physical health problems over the past month.

Autor and Mark Duggan (2003) depict disability insurance as a substitute for unemployment insurance that may be better seen as a social cost of nonemployment, rather than an independent insurance program. Andreas Kostol and Magne Mogstad (2014) show that when disabled people in Norway are able to keep more of their earnings, they work and earn more. Nicole Maestas, Kathleen Mullen, and Alexander Strand (2013) examine borderline applicants for Social Security Disability Insurance, and find that employment would have been 28 percentage points higher among successful applicants if they had not received benefits. Eric French and Jae Song (2014) find a similar decrease in employment among applicants who successfully appeal their applications compared with those who are unsuccessful. These papers suggest that at least part 
Table 8. Expenditures of Prime Age Men, 2016

\begin{tabular}{lcccr} 
Income or expenditure & $\begin{array}{c}\text { Employed, } \\
\text { total }\end{array}$ & $\begin{array}{c}\text { Employed, } \\
\text { living alone }\end{array}$ & $\begin{array}{c}\text { Employed, } \\
\text { living alone, } \\
\text { low income } \text { loc }^{\mathrm{b}}\end{array}$ & $\begin{array}{c}\text { Long-term } \\
\text { not } \text { working, } \\
\text { living alone }\end{array}$ \\
\hline Pretax household income & 98,575 & 55,898 & 22,190 & 12,870 \\
Tax & 15,397 & 9,449 & 1,326 & 566 \\
Posttax household income & 83,170 & 46,444 & 20,861 & 12,301 \\
Total expenditures & 64,694 & 43,508 & 28,086 & 20,686 \\
$\quad$ Food & 9,491 & 6,506 & 5,091 & 3,830 \\
Housing & 21,250 & 14,752 & 10,857 & 9,221 \\
Apparel and services & 1,283 & 721 & 452 & 336 \\
Transportation & 10,297 & 6,935 & 4,664 & 2,918 \\
Personal care & 349 & 168 & 129 & 55 \\
Health care & 3,963 & 2,099 & 1,222 & 1,044 \\
Entertainment & 3,024 & 2,015 & 1,159 & 975 \\
Alcohol & 722 & 766 & 475 & 179 \\
Tobacco products & 325 & 345 & 398 & 459 \\
Other expenditures & 13,989 & 9,200 & 3,639 & 1,669 \\
\hline
\end{tabular}

Sources: U.S. Bureau of Labor Statistics, Consumer Expenditure Survey; authors' calculations.

a. The sample includes noninstitutionalized prime age men. The units are dollars

b. Respondents are classified as living alone if there are no other residents age 18 or over in the household.

c. Respondents are classified as low income if their household pretax income is less than $\$ 40,000$.

d. Long term is defined as more than 12 months.

of the disability cost should be seen as a fiscal externality generated by nonemployment.

In table 8, we turn to expenditures, using data from the Consumer Expenditure Survey. We split the population into employed, employed living alone, low-income employed (again, earning less than $\$ 40,000$ a year), and the long-term not working living alone.

The not working, unsurprisingly, pay far fewer taxes than employed men generally, who pay over $\$ 15,000$ annually, or employed men living alone, who pay almost $\$ 10,000$. However, if the comparison is with low-income men living alone, the gulf in taxes is much smaller. The not-working men living alone contribute $\$ 566$ in taxes, as opposed to $\$ 1,326$ in taxes for the low-income employed living alone.

If the relevant margin is between nonemployment and average earnings, then the tax-related fiscal externality is over $\$ 9,000$. If the relevant margin is between nonemployment and low-income wage labor, then the tax-related fiscal externality is much smaller, closer to $\$ 800$.

Perhaps the most surprising fact is that the expenditures of the not working are much higher than their income level, and are not that much lower 
than the expenditures of the low-income employed, who spend $\$ 28,100$ annually; the not working who live alone spend $\$ 20,700$. The plausible explanations for this group's gap between expenditures and earnings include running down savings, borrowing, unreported family transfers, and perhaps even illicit earnings. Typically, the members of this group have neither significant assets nor great credit, which makes it hard to believe that past savings and borrowing can explain the gap. They also report low levels of family transfers.

The small gap in spending between the low-income employed and the not working suggests that the Keynesian externalities associated with moving the not working into low-wage jobs are small. The largest spending increase associated with employment is transportation, which may reflect the costs of getting to and from work. Annually, the employed also spend $\$ 300$ more on alcohol, $\$ 1,600$ more on housing, and $\$ 1,300$ more on food. The greater food expenditure may reflect some eating out on the job.

Do these data suggest a large fiscal externality from nonemployment? Benefits fall by $\$ 4,900$ and taxes fall by $\$ 800$ when we compare the not working with low-wage workers. If half the disability payments would have been paid in any case, then the benefit gap drops to $\$ 3,200$, making the total fiscal externality $\$ 4,000$, which is 21 percent of the earnings of the low-income individuals.

\section{IV.B. Social Externalities Borne by Families and Friends}

We now turn to the costs of nonemployment that are borne by family and friends. A large share of the long-term not working do not live alone, but many of these men are not married. Figure 17 shows the time series of the share of men who have never been married, for the employed, the short-term not working, and the long-term not working. The three lines show parallel upward trends, with the not working always being less likely to have been married than the employed. By 2015, half of the long-run not working have never been married, and over 40 percent of the short-term not working have never been married. Less than 30 percent of the employed have never been married.

The share of the employed who are separated or divorced has risen over time. The share of the not working who are separated or divorced has remained steady, at over 15 percent, as shown in figure 18. Consequently, less than 35 percent of the long-term not working have current spouses, and the majority of their cohabitants are not their current spouses. 
Figure 17. The Prevalence of Singleness, 1980-2015

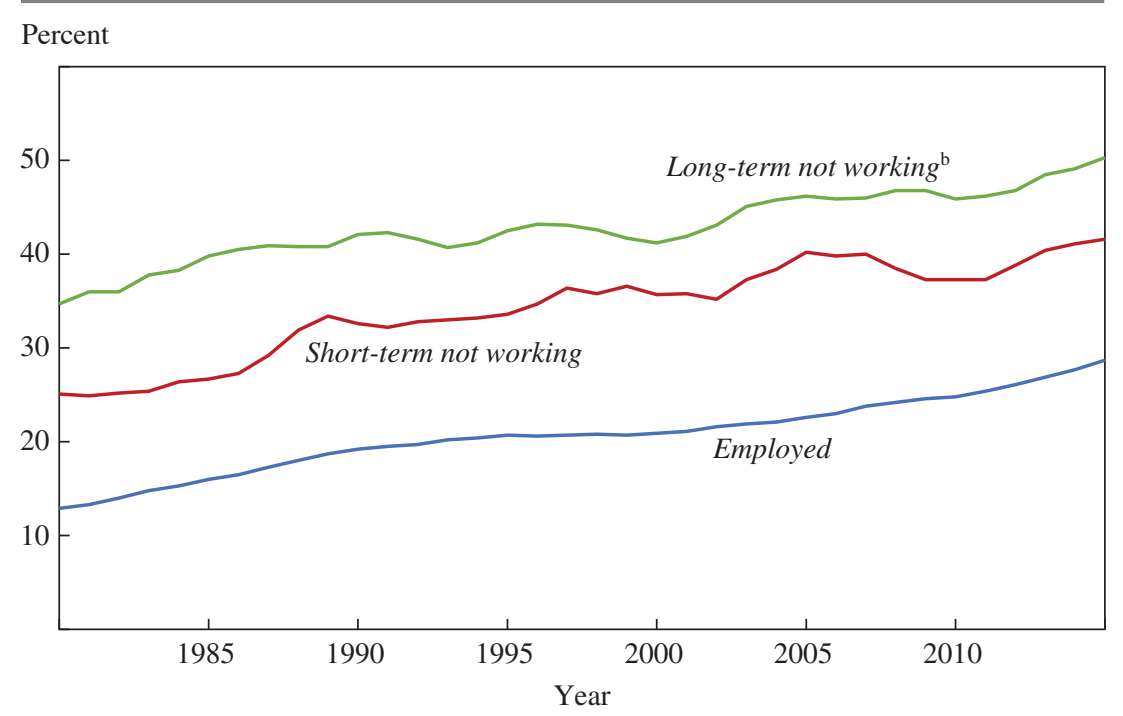

Sources: U.S. Census Bureau, Current Population Survey, Annual Social and Economic Supplement; IPUMS; authors' calculations.

a. This figure shows the share of respondents who have never been married. The series are three-year pooled moving averages. The sample includes civilian noninstitutionalized prime age men in the continental United States (excluding the District of Columbia).

b. Long term is defined as more than 12 months.

In many cases, the not working are actually living with their parents. Figure 19 shows the trend in cohabitating with parents by employment status. This number has always been high for the long-run not working, but it has risen in recent years to over 30 percent.

Does not working also impose externalities on family and friends who subsidize the not working? If nuclear families are unitary decisionmakers, then they are presumably making joint decisions about work and leisure. If men make independent decisions about work, and then spouses bargain ex post about the share of rents, spouses will presumably lose their share of the forgone earnings.

Some of these externalities will be offset if the not-working spouse participates more in household production, but time use surveys suggest that this is not the case. Table 9 shows the time use by employed and notworking men by region.

Working men spent about 530 minutes ( 8 hours 50 minutes) per day on personal care, over 90 percent of which was typically sleep. They worked 
Figure 18. The Prevalence of Separation and Divorce, $1980-2015^{\mathrm{a}}$

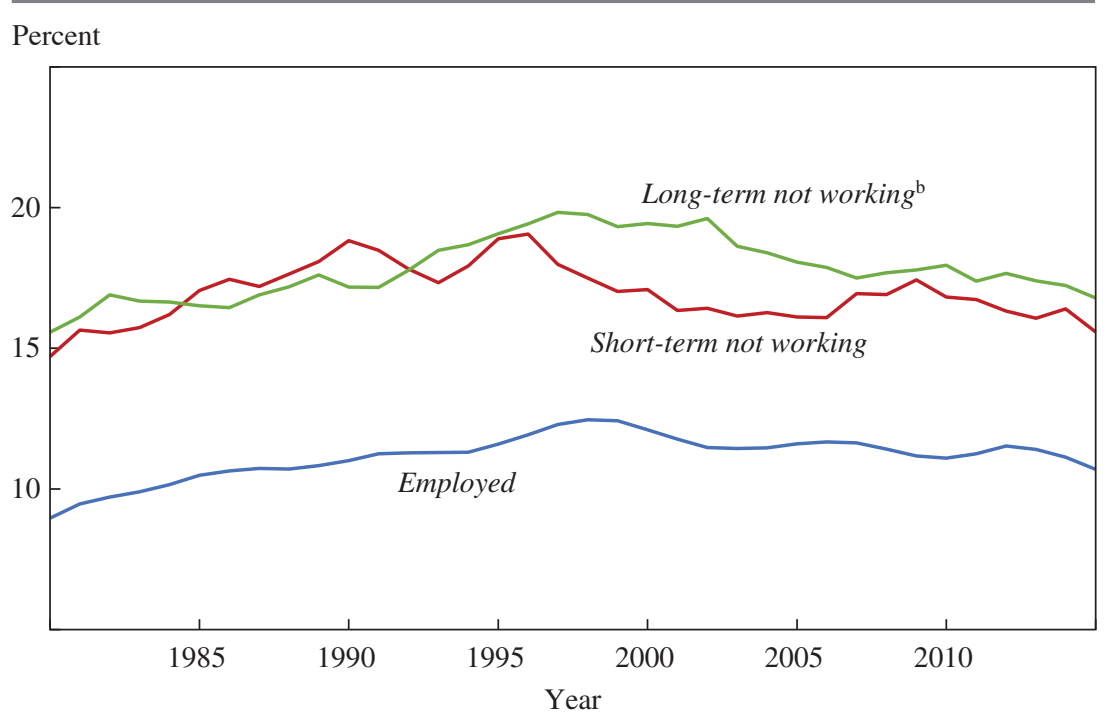

Sources: U.S. Census Bureau, Current Population Survey, Annual Social and Economic Supplement; IPUMS; authors' calculations.

a. This figure shows the share of respondents who have been separated or divorced from their spouses. The series are three-year pooled moving averages. The sample includes civilian noninstitutionalized prime age men in the continental United States (excluding the District of Columbia).

b. Long term is defined as more than 12 months.

an average of between 382 and 401 minutes per day, which roughly corresponds to a 6.5 hour workday, averaged over the course of the week. Notably, the men in the western heartland do seem to put in longer hours. They offset this time by spending slightly less time on leisure activities. Watching television remains the dominant use of leisure time and takes up slightly over 2 hours per day for working men.

Not-working men work about 6 hours less per day. This extra time is spent primarily on leisure activities. The not working in the eastern heartland spend over 5 hours daily watching television. There is also an uptick in computer use, including gaming, as noted by Aguiar and others (2017) and Krueger (2017).

The not-working men on the coasts and in the western heartland increase their time spent on household production tasks by 41 and 46 minutes, respectively. The modal categories for male household activities are food preparation and lawn work. Consequently, even for this group, less than one-sixth of the time freed up by not working goes to activities that benefit 
Figure 19. The Prevalence of Living with a Parent, 1980-2015

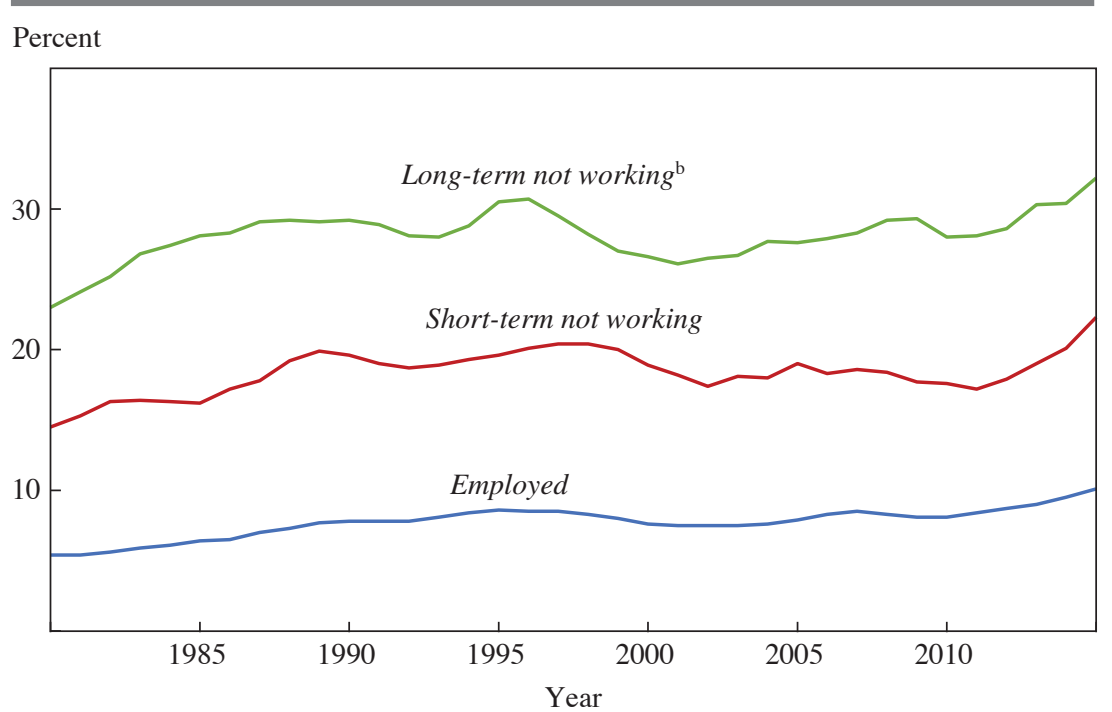

Sources: U.S. Census Bureau, Current Population Survey, Annual Social and Economic Supplement; IPUMS; authors' calculations.

a. This figure shows the share of respondents who currently live with a parent. The series are three-year pooled moving averages. The sample includes civilian noninstitutionalized men in the continental United States (excluding the District of Columbia).

b. Long term is defined as more than 12 months.

Table 9. Time Use by Prime Age Men, 2003-16

\begin{tabular}{|c|c|c|c|c|c|c|}
\hline \multirow[b]{2}{*}{ Activity } & \multicolumn{3}{|c|}{ Employed } & \multicolumn{3}{|c|}{ Not working } \\
\hline & Coasts & $\begin{array}{c}\text { Eastern } \\
\text { heartland }\end{array}$ & $\begin{array}{l}\text { Western } \\
\text { heartland }\end{array}$ & Coasts & $\begin{array}{c}\text { Eastern } \\
\text { heartland }\end{array}$ & $\begin{array}{c}\text { Western } \\
\text { heartland }\end{array}$ \\
\hline Personal care & 530 & 529 & 529 & 598 & 604 & 587 \\
\hline Household activities & 74 & 83 & 75 & 115 & 114 & 122 \\
\hline Food preparation & 76 & 73 & 76 & 67 & 62 & 62 \\
\hline Caring for others & 41 & 42 & 41 & 56 & 51 & 53 \\
\hline Working & 392 & 382 & 401 & 33 & 28 & 32 \\
\hline Searching for work & 1 & 1 & 1 & 21 & 16 & 21 \\
\hline Education & 6 & 5 & 6 & 35 & 22 & 38 \\
\hline Leisure & 257 & 262 & 248 & 450 & 481 & 449 \\
\hline Socializing & 36 & 37 & 34 & 51 & 57 & 56 \\
\hline Watching TV & 137 & 142 & 133 & 258 & 303 & 269 \\
\hline Computer use $\mathrm{e}^{\mathrm{b}}$ & 17 & 17 & 17 & 41 & 34 & 37 \\
\hline No. of observations & 19,213 & 9,738 & 10,258 & 2,590 & 1,480 & 1,068 \\
\hline
\end{tabular}

Sources: U.S. Census Bureau, American Time Use Survey; IPUMS; authors' calculations.

a. The sample includes civilian noninstitutionalized prime age men in the continental United States (excluding the District of Columbia). The data are pooled over 2003-16. The weighted means include respondents who report zero time spent on an activity. Except for the final row, the units are minutes per day.

b. Computer use includes playing games (activity 120307) and computer use for leisure, excluding games (activity 120308). 
the household rather than private consumption. By contrast, not-working men in the eastern heartland spend only 31 more minutes on household activities than working men and 9 more minutes caring for others.

The view that spouses are not benefiting from their partners' nonemployment is further supported by the correlation between not working and divorce rates. It is not merely that the not working are more likely to be divorced. Losing one's job is associated with a higher risk of becoming divorced (Killewald 2016). Although this fact has many interpretations, one view is that a male's nonemployment is a negative shock to his spouse.

We take the stand that bargaining is efficient between spouses, but not between parents and children. Consequently, for the roughly one quarter of not-working people who live with their parents, nonhousing expenditures represent an externality from nonemployment. The long-term not working who live alone have total nonhousing expenditures of $\$ 11,500$. Consequently, not working generates an average family externality of $\$ 2,900$, which is 15 percent of low-wage income. This figure is a crude attempt to capture intrafamily losses ("internalities") and the more general spillovers from not working that we discuss next, collectively bringing the total externality to $\$ 6,900$, which is 36 percent of low-wage earnings.

\section{IV.C. Nonemployment Spillovers}

The suffering of not working will be magnified if not working spills over across individuals. This spillover could occur because an individual's not working leads to less demand for local products, which reduces local labor demand. Nonemployment could also spill over if it reduces the stigma of not working (Lindbeck, Nyberg, and Weibull 1999), if it creates a culture of not working, or if the not working enjoy being with each other. ${ }^{31}$

Giorgio Topa (2001) presents the now-standard model of this phenomenon. He estimates this model using tract-level data from Chicago, using a structural model. The sorting of the unemployed within the city provides evidence supporting the view that the unemployment of one person is a complement to the unemployment of his or her neighbor. Timothy Conley and Topa (2002) extend this analysis.

Clark (2003) provides evidence for the social norm hypothesis. He finds evidence that the self-reported life satisfaction of the unemployed is much

31. The welfare effects of such spillovers would be ambiguous. Not-working people benefit from having more not-working friends, even if others pay the costs of a generally higher not-working rate. 
higher if there is more unemployment in the individual's reference group. $\mathrm{He}$ also finds that individuals whose unhappiness drops more at the point of unemployment are more likely to find future employment. These findings seem to suggest that a norm of not working translates into still more long-term nonemployment. A final piece of evidence supporting the nonemployment spillover hypothesis is that aggregate employment relationships with variables like tax rates are often much stronger than individual employment relationships (Alesina, Glaeser, and Sacerdote 2005), which suggests the existence of a social multiplier.

\section{Calibrating the Level of Place-Based Interventions}

We now use the modified Baily-Chetty formula discussed in section II, and attempt to obtain quantitative estimates of the optimal degree of place-based heterogeneity. We consider two thought experiments. First, we assume that existing benefits continue in place, and we estimate the optimal allocations of new employment subsidy across space. The relevant first-order condition for such an employment subsidy bonus is that $V^{\prime}\left(w_{p}+e_{p}\right) /\left[1-\varepsilon_{W}^{p}\left(b_{p}+k-e_{p}\right) / w_{p}\right]$ must be constant over space. Second, we assume that funds are removed from current benefits received by the not working and are allocated to marginal workers. In this case, the relevant first-order condition is $V^{\prime}\left(w_{p}+e_{p}\right) / V^{\prime}\left(d_{p}+b_{p}\right)=1-\varepsilon_{W}^{p}\left(b_{p}+k-e_{p}\right) /$ $w_{p}\left[1-F_{p}\left(c_{p}^{*}\right)\right]$. Our model does not incorporate wage effects of subsidies, or migration and capitalization, which could be significant by-products of the first thought experiment but not the second one. Consequently, these calculations are illustrative at best.

In both cases, we depend on place-specific estimates of the extensive margin elasticity of labor supply. Our purpose here is to emphasize the heterogeneity across the United States, not to advance the considerable literature on labor supply. ${ }^{32}$ We use a simple empirical approach, regressing the log employment rate at the PUMA level on the log wages for the 25th percentile of employed men. We instrument for wages using Bartik shocks, as described above. The use of Bartik shocks as an instrument for labor demand is discussed in detail by Paul Goldsmith-Pinkham, Isaac Sorkin,

32. For example, Juhn, Murphy, and Topel (1991) find that partial elasticity varies depending on the income distribution of men, with an average value of 0.13 and a high value of 0.35 for men in the 10th percentile of income. Meghir and Phillips (2010) similarly find a higher elasticity of 0.4 for low-income men in the United Kingdom. Broader reviews include those by Blundell and MaCurdy (1999) and Chetty and others (2013). 
Table 10. Estimating the Elasticity of the Labor Supply

\begin{tabular}{|c|c|c|c|c|}
\hline & $\begin{array}{l}(1) \\
O L S\end{array}$ & $\begin{array}{l}(2) \\
I V\end{array}$ & $\begin{array}{l}(3) \\
O L S\end{array}$ & $\begin{array}{l}(4) \\
I V\end{array}$ \\
\hline $\log _{\text {wage }}{ }^{b}$ & $\begin{array}{l}-0.038 \\
(0.027)\end{array}$ & $\begin{array}{l}-0.093 \\
(0.080)\end{array}$ & $\begin{array}{l}-0.008 \\
(0.021)\end{array}$ & $\begin{array}{c}0.022 \\
(0.075)\end{array}$ \\
\hline Not-working rate, $1980^{\circ}$ & $\begin{array}{l}-12.248 * * * \\
(2.874)\end{array}$ & $\begin{array}{l}-22.633 * * * \\
(4.144)\end{array}$ & $\begin{array}{l}-12.611 * * * \\
(2.624)\end{array}$ & $\begin{array}{l}-28.768 * * * \\
(6.019)\end{array}$ \\
\hline $\begin{array}{l}\text { Log wage } \times \text { not-working } \\
\text { rate, } 1980^{\text {b,c }}\end{array}$ & $\begin{array}{l}1.102 * * * \\
(0.277)\end{array}$ & $\begin{array}{l}2.126 * * * \\
(0.404)\end{array}$ & $\begin{array}{l}1.152 * * * \\
(0.256)\end{array}$ & $\begin{array}{l}2.772 * * * \\
(0.599)\end{array}$ \\
\hline $\begin{array}{l}\text { College graduation rate, } \\
1980^{\mathrm{d}}\end{array}$ & $\begin{array}{c}0.009 \\
(0.032)\end{array}$ & $\begin{array}{c}0.045 \\
(0.052)\end{array}$ & $\begin{array}{c}0.028 \\
(0.029)\end{array}$ & $\begin{array}{r}0.112^{*} \\
(0.064)\end{array}$ \\
\hline $\begin{array}{l}\text { Share with less than a } \\
\text { high school education, } \\
1980^{\mathrm{e}}\end{array}$ & $\begin{array}{l}-0.097 * * \\
(0.042)\end{array}$ & $\begin{array}{l}-0.029 \\
(0.061)\end{array}$ & $\begin{array}{l}-0.107 * * \\
(0.049)\end{array}$ & $\begin{array}{l}0.118 \\
(0.126)\end{array}$ \\
\hline Period fixed effects & Yes & Yes & Yes & Yes \\
\hline State fixed effects & No & No & Yes & Yes \\
\hline \multicolumn{5}{|l|}{ Implied elasticity } \\
\hline Wyoming & 0.03 & 0.05 & 0.07 & 0.20 \\
\hline West Virginia & 0.14 & 0.26 & 0.18 & 0.48 \\
\hline \multicolumn{5}{|l|}{ First-stage $F$ statistic } \\
\hline Log wage & & 14.6 & & 14.4 \\
\hline Interaction term & & 8.4 & & 7.3 \\
\hline No. of observations & 1,614 & 1,614 & 1,614 & 1,614 \\
\hline
\end{tabular}

Sources: U.S. Census Bureau, 1980, 1990, and 2000 censuses, American Community Survey; IPUMS; authors' calculations.

a. The dependent variable is the log employment-to-population ratio. Data for 1980, 1990, and 2000 are from the decennial censuses; data for 2010 are pooled 2009-11 data from the American Community Survey. The sample includes civilian noninstitutionalized prime age men in 1980-2000 consistent Public Use Microdata Areas in the continental United States (excluding the District of Columbia). Robust standard errors clustered by state are in parentheses. Statistical significance is indicated at the ***1 percent, **5 percent, and * 10 percent levels.

b. Log wage, expressed in 2016 dollars, is the 25 th percentile of total annual wages for respondents who are currently employed. Changes in log wages are instrumented using Bartik employment growth shocks, which are calculated based on predicted growth in employment based on 1980 industry shares within Public Use Microdata Areas and industry employment growth rates for all workers in the continental United States.

c. The not-working rate is defined as the share of the population not currently employed.

d. The college graduation rate is defined as the share of respondents who report completion of four or more years of college.

e. The share with less than a high school education is defined as the share of respondents who report completion of eleven or fewer years of education in the 1980 sample.

and Henry Swift (2018). They show that using Bartik shocks as instruments is numerically equivalent to using industry shares as instruments. Therefore, identification is dependent on the exogeneity of initial industry shares.

Table 10 summarizes the results. The coefficient on log wages is small and insignificant, but the interaction of wages and the 1980 not-working rate is large and significant. The measured elasticity varies over space, with 
greater responsiveness in areas with high not-working rates. Wyoming had the lowest not-working rate in 1980, at 6.5 percent, and the implied elasticity is 0.05 . West Virginia had the highest not-working rate in 1980, at 16.5 percent, and the implied elasticity is 0.26 . We hope that this simple approach will be superseded in future work that will bring more sophisticated estimation techniques to assess the heterogeneity of labor supply elasticities across space.

We assume a constant relative risk aversion utility function, with a coefficient of relative risk aversion of $\gamma$. Steffen Andersen and others (2008) estimate that this coefficient is 0.741 in laboratory experiments with relatively low stakes. Alma Cohen and Liran Einav (2007) estimate a median coefficient of relative risk aversion of 0.37 from deductible choices in automobile insurance. Robert Barsky and others (1997) find evidence for higher values using larger gambles. Some macroeconomic estimates associated with explaining the equity premium puzzle are higher still. We report values assuming coefficients of $0.5,1.0$, and 2.0.

We start with the employment subsidy formula

$$
\frac{V^{\prime}\left(w_{p}+e_{p}\right)}{\left[1-\frac{\varepsilon_{W}^{p}\left(b_{p}+k-e_{p}\right)}{w_{p}}\right]}=\theta,
$$

and we implement it by one region, indexed $A$, and with a benchmark region, indexed 0 , where $\varepsilon_{w}^{0}=0$, and $e_{0}=0$. Essentially, we are asking how much larger a region's employment subsidy should be than a place where there is no employment response to wages and consequently no employment subsidy. We assume that the marginal worker's wage is everywhere fixed at $w_{0}$ and independent of the employment subsidy, perhaps because the wage is determined by the federal minimum wage. We also assume that $\left(b_{A}+k\right) / w_{A}=0.363$. With those assumptions, $V^{\prime}\left(w_{0}+e_{A}\right) / V^{\prime}\left(w_{0}\right)=$ $1-0.363 \varepsilon_{W}^{A}+e_{A} / w_{0} \varepsilon_{W}^{A} \cdot{ }^{33}$

Given our estimates of differential employment elasticity, we can then consider the optimal subsidy. For example, states such as Wyoming that have low not-working rates have an estimated elasticity close to 0 , suggesting a minimal optimal employment subsidy. Areas such as West Virginia

33. We make the simplifying assumption that the labor elasticity in the region is constant as we change the employment subsidy. We recognize that this is not entirely accurate, and a more complete calibration would involve imputing the reservation wages for not-working men in each region. 
Figure 20. Model Calibration for a Benefits Twist

Optimal benefits twist relative to wage

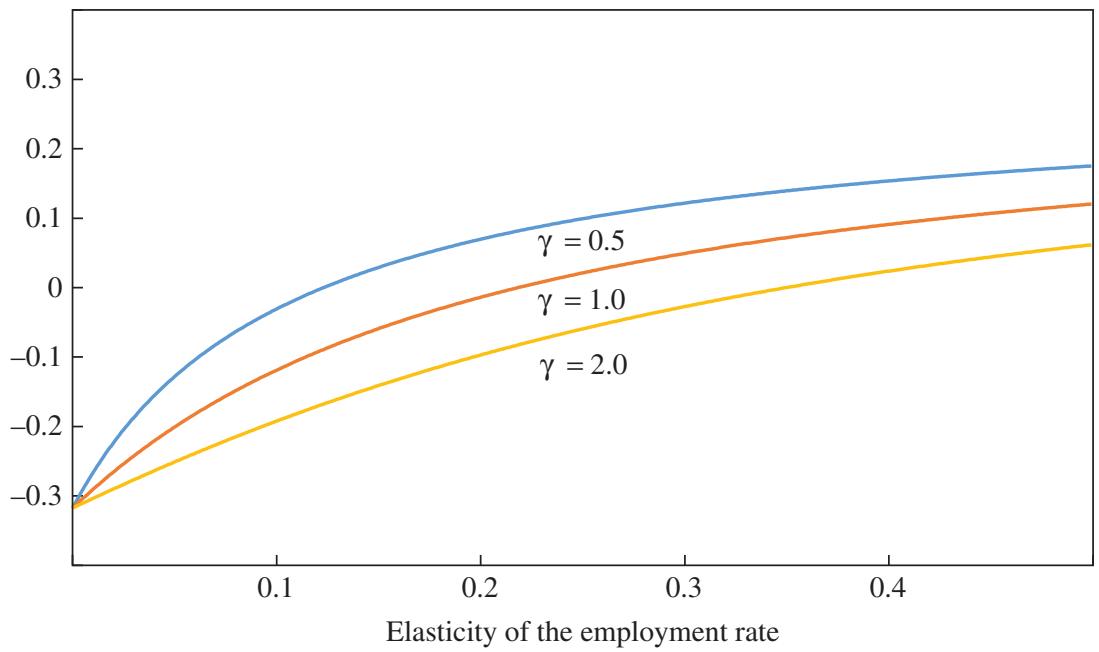

Source: Authors' calculations.

with high not-working rates, with an estimated elasticity of 0.26 , have an optimal subsidy equal to 14 percent of wages if the coefficient of relative risk aversion is 0.5 , an optimal subsidy of 8 percent of wages if the coefficient is 1 , and an optimal subsidy of less than 5 percent of wages if the coefficient is 2. High coefficients mean strong concavity, which reduces the benefits of the employment subsidy.

The previous thought experiment was a bonus that just allocated employment dollars to states with high not-working rates. Our alternative thought experiment is a twist that reallocates $x \cdot w_{p}$ dollars from not-working benefits and adds $\left[1-F_{p}\left(c_{p}^{*}\right)\right] / F_{p}\left(c_{p}^{*}\right) \cdot x \cdot w_{p}$ to the employment subsidy. We assume that $e_{p}=0$ without this subsidy. We assume that $d_{p}+b_{p}=0.6 w_{p}$, which is in line with tables 6 and 8. In this case, the modified Baily-Chetty condition in equation 2 implies

$$
0.6-x=\left[1+\frac{1-F_{p}\left(c_{p}^{*}\right)}{F_{p}\left(c_{p}^{*}\right)} x\right] \cdot\left[1-\frac{0.363 \varepsilon_{W}^{p}}{1-F_{p}\left(c_{p}^{*}\right)}+\frac{\varepsilon_{W}^{p}}{F_{p}\left(c_{p}^{*}\right)\left[1-F_{p}\left(c_{p}^{*}\right)\right]} x\right]^{1 / \gamma} .
$$

Figure 20 illustrates the optimal benefits twist as a function of $\varepsilon_{w}^{p}$ for the three different cases of constant relative risk aversion utility. 
Table 11. Estimates of the Optimal Consumption Ratio of Not-Working Individuals to Employed Individuals

\begin{tabular}{lccc}
\hline Estimate & Wyoming & Massachusetts & West Virginia \\
\hline At-risk not-working rate (2014-16) & 39.5 & 48.6 & 61.3 \\
Elasticity of the employment rate & 0.05 & 0.12 & 0.26 \\
Externality as a percentage of wages & 36.3 & 36.3 & 36.3 \\
Ratio of consumption & & & \\
$\quad \gamma=0.5$ & 0.919 & 0.831 & 0.718 \\
$\gamma=1.0$ & 0.958 & 0.911 & 0.848 \\
$\gamma=2.0$ & 0.979 & 0.955 & 0.921 \\
\hline
\end{tabular}

Sources: U.S. Census Bureau, Current Population Survey; IPUMS; authors' calculations.

Again, we can match the theoretical predictions against different states. In states with low elasticities, we find that the optimal size of the benefits twist is negative, so the optimal change to the benefit scheme would be to increase benefits for the not working by increasing taxes. ${ }^{34}$ Indeed, if the coefficient of relative risk aversion is 2 , then the model almost always pushes toward more transfers for the not working because of such strong concavity. When the coefficient of risk aversion is 0.5 , again the model suggests a positive benefits twist, with a reallocation of 10 percent or more in states like West Virginia, depending on the elasticity.

Finally, we can calculate the predicted optimal ratio of consumption when working or not working in different states, based on their employment and not-working shares. Our ratio of the fiscal and other externalities of not working to the wage is 0.363 , from the previous section. The not-working rate is somewhat more complicated, given that this is the share of the low-skill, at-risk workers who are not working, not the not-working share of the entire population. We use our previous definition of low-income men as those who are employed and have a total annual family income of less than $\$ 40,000$. Using this definition, we find that the not-working rate for at-risk workers varies from 39.5 percent in Wyoming to 61.3 percent in West Virginia, using the 2014-16 pooled responses from the ASEC.

Table 11 summarizes our results. Our model predicts that the ratio of consumption of not-working to employed men should indeed be lower in areas with high not-working rates. Although these values are only tentative, they illustrate the importance of considering spatially heterogeneous policy responses to nonemployment.

34. In a broader model, the funds could come from other sources than just taxes on low-income earners. 
We view these results as thought experiments, not serious policy proposals. These calculations suggest that if utility functions are not too concave, then significantly stronger subsidies for employment would be optimal for states like West Virginia. This conclusion would be tempered if wages fell with subsidies, or if the subsidies distorted migration. If migration were a paramount concern, then our model suggests that there could even be welfare gains in areas with high not-working rates from replacing benefits for the not working with benefits subsidizing marginal workers. In areas with low not-working rates, more benefits for the not working would be welfare-enhancing, especially when risk aversion is high.

\section{Place-Based Policies: Efficacy, Capitalization, and Mobility}

We now turn to a brief taxonomy of place-based policies in the United States and elsewhere. Our goal is to link these policies with the three objectives discussed above, and to discuss the evidence on their downsides, including capitalization, distorted location choice, and overall cost. We do not focus on the spatial heterogeneity that occurs because of differences in local government actions, but rather on ways in which national governments and the European Union generate policies with spatially heterogeneous effects. A central theme of this section is that spatial policies have the largest impact when they are targeted toward the needs and problems of particular regions.

\section{VI.A. A Taxonomy}

Spatial policies can be explicit, openly targeting one area or another, or implicit, aiding particular areas disproportionately, but without an acknowledgment of the geographic tilt. Spatial policies can take the form of direct public investment, tax benefits or subsidies to businesses, tax benefits or grants to individuals, and regulatory relief. Table 12 provides a brief summary of the eight categories in our taxonomy, with a few examples of each form.

\section{VI.B. Direct Public Investment}

A prime example of direct public investment is the Tennessee Valley Authority (TVA), which was a New Deal innovation meant to deliver electricity and improve conditions in one of the poorest parts of the country. The TVA began not with a desire for a spatial big push but with the recognition that electricity could have high returns and could be produced by the region's abundant hydropower. Kline and Moretti (2013) provide evidence showing that the TVA increased agricultural employment in the region 
Table 12. A Taxonomy of Place-Based Policies

\begin{tabular}{|c|c|c|}
\hline Policy & Explicitly spatial & Implicitly spatial \\
\hline $\begin{array}{r}\text { Direct public } \\
\text { investment }\end{array}$ & $\begin{array}{l}\text { Tennessee Valley Authority } \\
\text { Appalachian Regional } \\
\text { Commission }\end{array}$ & $\begin{array}{l}\text { Interstate Highway System } \\
\text { Relocation of public offices }\end{array}$ \\
\hline $\begin{array}{l}\text { Tax benefits or grants } \\
\text { for businesses }\end{array}$ & $\begin{array}{l}\text { New Markets Tax Credit } \\
\text { Program } \\
\text { Cassa del Mezzogiorno }\end{array}$ & $\begin{array}{l}\text { Agricultural subsidies } \\
\text { Oil depletion allowance }\end{array}$ \\
\hline $\begin{array}{l}\text { Tax benefits or grants } \\
\text { for individuals }\end{array}$ & $\begin{array}{l}\text { Northern Norway tax benefits } \\
\text { Customized training programs }\end{array}$ & $\begin{array}{l}\text { Flood insurance } \\
\text { Nominal tax credits } \\
\text { State and local tax deductibility }\end{array}$ \\
\hline Regulatory relief & $\begin{array}{l}\text { Chinese special economic } \\
\text { zones } \\
\text { Devens Enterprise } \\
\text { Commission }\end{array}$ & $\begin{array}{l}\text { Channel Islands financial haven } \\
\text { Heterogeneous environmental } \\
\text { regulations }\end{array}$ \\
\hline
\end{tabular}

while subsidies were in place and increased manufacturing employment even after the subsidies ended. They interpret their findings as suggesting that the TVA generated durable agglomeration economies. An alternative interpretation is that the TVA was successful because it delivered electricity, which had a particularly high return in the Tennessee Valley.

Kline and Moretti (2013) also provide evidence relevant for both capitalization and mobility. None of their specifications show a positive impact of the TVA on population growth in the region, suggesting that there were minimal distortions of location choice, which perhaps reflect the fact that the TVA was supposed to pay for itself eventually. In some, but not all, of their specifications, there is a positive impact on median home value. Yet these positive effects do not withstand the inclusion of other controls.

The second particularly well-known spatial program in the United States was the Appalachian Regional Commission, which became a federal agency in 1965. The commission's formation was motivated by local poverty, not any obvious economic opportunity, and its geographic scope runs through 13 states and includes all of West Virginia. The commission provides grants in many areas, but its signature project is the Appalachian Development Highway System, which provides highway access throughout the region. Economic conditions in the affected counties did seem to improve during the 1970s, but there is little evidence of any more durable economic transformation (Glaeser and Gottlieb 2008). The program's scale was modest, relative to the size of the region, which makes ex post evaluation difficult. Nonetheless, the commission's limited success surely reflects its failure to find a high-return regional intervention. 
The European Union's cohesion policy is a much larger example of spatially targeted public investment. The policy's explicit goal is to reduce income disparities within the EU region, partially to reduce the political tensions that can come with heterogeneity. The policy differentiates at the subnational level-thus, for instance, though Warsaw is considered more developed, the rest of Poland is considered less developed. Michele Boldrin and Fabio Canova (2001) and Sandy Dall'Erba and Julie Le Gallo (2007) both conclude that this policy is ineffective. Aadne Cappelen and others (2003) find modest positive effects, which are larger in the more developed EU countries. Again, the policies seem to have a limited effect because they focus on spreading money around rather than on interventions that have high returns in particular places.

Within the United States and elsewhere, spatially motivated infrastructure investment has been much less important to spatial development than nonspatially motivated infrastructure investment. The federal Interstate Highway System, for example, was not intended to help suburbanize America or to strengthen particular communities relative to others. Yet Nathaniel Baum-Snow (2007) finds that each new highway that was built in a metropolitan area with federal support after World War II reduced the central city's population by 18 percent. Gilles Duranton and Matthew Turner (2012) find significant effects of highway construction on the economic development of connected metropolitan areas. The large mobility effects of the highway system reflect the fact that the system delivered mobility that was valued by millions of Americans. ${ }^{35}$

Although David Aschauer (1989), Alicia Munnell (1992), and others have found positive effects of infrastructure on local economic activity, Andrew Garin (2016) finds almost no impact of transportation spending under the American Recovery and Reinvestment Act on employment. One interpretation of the difference is that earlier studies focused on a period when infrastructure brought high value to drivers and consequently also moved activity across space. Edward Gramlich (1994), in particular, is associated with the view that the returns to infrastructure have declined over time. The modest impact of recent subways on urban structure (Baum-Snow and Kahn 2005) is compatible with the view that

35. A host of studies also find effects of highways on local property values (Chernobai, Reibel, and Carney 2011). A working version of the paper by Duranton and Turner (2012) found that more highway miles were associated with slight decreases in the number of poor people and the number of high school dropouts, suggesting that if anything the sorting effects of infrastructure are slightly positive. 
investments that are poorly targeted toward local demand also have little spatial impact.

Supporters of spatial targeting for direct government spending sometimes argue that in some cases, spatial effects can be generated at a moderate cost. For example, if the government is going to spend a fixed amount on the military, then locating an installation in Mississippi rather than New York may be largely irrelevant to any military objectives. Nakamura and Steinsson (2014) find significant effects of military spending on the local economy. Giulia Faggio and Henry Overman (2014), however, use quasiexogenous shifts in the size of local government to estimate the spillovers from increases in public employment. They find that 1 extra job in the public sector generates 0.5 extra service sector job and crowds out 0.4 tradable sector job. ${ }^{36}$ One explanation for the difference may be that nonmilitary employment crowds out local jobs, but military employment is sufficiently different so that it does not.

Land grant colleges may have been the federal government's most successful foray into place-making. ${ }^{37}$ These educational institutions, subsidized with federal land, are strongly associated with high incomes (Moretti 2004) and population growth during recent decades (Glaeser and Saiz 2004). Once again, these interventions seem to have been spatially effective because they have supported an activity that was thought to have high returns regardless of any spatial dimension.

Most direct public investment is probably most compatible with the agglomeration-related justifications for spatial intervention. Indeed, one interpretation of the TVA's results is that this investment generated a "big push" that took advantage of convex agglomeration economics. We are far from confident about economists' current ability to identify such opportunities. The general existence of agglomeration economies may support the case for national proinvestment policies, such as reducing taxes on capital gains, but unless we understand the spatial heterogeneity of agglomeration effects, the existence of agglomerations does not justify spatially heterogeneous polices.

36. Ades and Glaeser (1995) argue that political forces explain why the capital cities of dictatorships and unstable democracies are about 40 percent larger than the capital cities of stable democracies. There is little doubt that enough government spending of the right kind can have an impact on a local economy.

37. A second unplanned federal place-making policy was the Bayh-Dole Act of 1980, which allowed researchers to capitalize on ideas developed with the support of federal grants. Hausman (2017) shows that economic activity increased around universities after the act. 
Most of the best agglomeration studies (Combes and others 2012) support the existence of agglomeration economies, but they give us little confidence about heterogeneity of local spillovers across space. The million-dollar plant identification strategy of Michael Greenstone, Richard Hornbeck, and Moretti (2010) provides little hope of identifying heterogeneous agglomeration effects because great swaths of America, especially the high-income coastal regions, were generally not recipients of these plants. Consequently, it is impossible to know whether a relocation of capital and labor from Los Angeles to Kentucky will lead to benefits in Kentucky that are large enough to offset the losses in Los Angeles.

\section{VI.C. Local Employment Subsidies}

The case for spatial targeting is that supporting employment may have a particularly high return in particular places. There is a serious body of literature that documents the effects of national employment subsidies. Jonathan Gruber (1997) finds that the elimination of the payroll tax in Chile was mostly passed along in the form of higher wages and did little for employment. James Heckman and Carmen Pagés (2004) find that between 0 and 60 percent of a firm's social security contributions in Latin America are passed along to workers in the form of lower wages. The EITC literature has typically found that most of the benefit of the credit accrues to workers (Rothstein 2010). The track record of local employment subsidies is more mixed, perhaps because they have not been targeted toward places where they would be most effective.

The literature on local employment subsidies is large and varied. Skepticism about direct government spending led the U.K. government of Margaret Thatcher toward a different approach: enterprise zones. Peter Hall (1982) is generally credited with the idea of reducing taxes and regulation in troubled urban areas. Despite his solid credentials as a social democrat, he had been impressed with the success of Hong Kong and Singapore, and he hypothesized that a similar light-handed touch could engender economic regeneration in Britain's troubled inner cities.

The Thatcher government embraced Hall's vision, and the United Kingdom began its program of providing tax benefits for firms operating in particular urban locations. Stuart Butler (1980) embraced the adoption of this approach in the United States. Although the federal government would not begin its program of "empowerment zones" until 1993, a plethora of states experimented with enterprise zones during the 1980s. The hallmark of such zones is that firms derive some tax benefit from operating within a disadvantaged area. 
Though enterprise and empowerment zones are typically targeted at small, depressed urban areas, other countries have offered tax incentives for businesses that locate in larger regions. Since 1987, Italy has offered corporate tax exemptions for firms operating in the poorer Mezzogiorno region, which includes southern Italy and Sicily. These incentives are larger for firms that fall within the government's favored industrial initiatives. France has been offering grants to firms that spread industry away from Paris since the 1960s. The Netherlands also offers targeted spatial incentives for businesses.

Barry Rubin and Craig Richards (1992) provided an early assessment of the effects of these zones in the United Kingdom and across U.S. states, and concluded that the U.K. experience was relatively unsuccessful. They estimate a cost per job of about $£ 50,000$, which annualizes to be about $\$ 14,000$ per job-year, which would be almost $\$ 30,000$ per job-year today. Leslie Papke (1994) relied on these figures in her assessment of the difficulties facing enterprise zones in the United States. Margaret Wilder and Rubin (1996) summarize a large number of early studies, and find wildly divergent effects. In some cases, the cost per job was as low as $\$ 1,000$.

In the past 20 years, the literature on state enterprise zones has grown, but results seem to be quite sensitive to the time period and approach. Daniele Bondonio and John Engberg (2000) and Robert Greenbaum and Engberg (2004) find little effect on employment or industrial expansion using a standard difference-in-differences approach. Suzanne O'Keefe (2004) compares enterprise zones in California with those in other areas that are matched using propensity score techniques. She finds a short-run 3 percent increase in employment associated with enterprise zone status, but less of a long-run effect.

Neumark and Jed Kolko (2010) use particularly fine-grained geography and find no impact of the California program. John Ham and others (2011) also use fine-grained geographies, and work hard to distinguish different programs. They find a negative impact on the unemployment rate, but do not find a positive impact on employment. Thus, if enterprise zones reduce unemployment but do not increase employment, then they must operate by reducing the amount of job seeking, which is a surprising finding.

The most impressive piece of recent research on zones is by Busso, Gregory, and Kline (2013), who come to a relatively positive conclusion about the impact of federal empowerment zones. They compare labor market outcomes in the first round of empowerment with a treatment group that consists of areas that also competed for zone status. They have access to confidential census micro data and find positive effects on employment, 
earnings, and housing prices. They do not see significantly rising rents in empowerment zones.

Busso, Gregory, and Kline's (2013) estimates have been used to produce a cost of only $\$ 18,000$ per job, although it is unclear how many years of employment this means. Nonetheless, this figure is quite low relative to other estimates, which are often closer to $\$ 100,000$. One interpretation of Busso, Gregory, and Kline's (2013) results is that the national empowerment zones subsidized employment in places where there was an abundance of potential employers and marginal workers. By contrast, the U.K. enterprise zones and state enterprise zones may have been more scattered.

Busso, Gregory, and Kline (2013) also find significant capitalization in housing values, but little in rents. Andrew Hanson (2009) and Douglas Krupka and Douglas Noonan (2009) find broadly similar results, again using a synthetic control group based on areas that applied for but did not receive empowerment zone status. Research on the capitalization of other social interventions into property values has been more limited. ${ }^{38}$

Gordon Betcherman, Meltem Daysal, and Pagés (2010) provide a particularly relevant analysis of spatially targeted employment subsidies in Turkey. They find that the employment subsidies did substantially increase jobs, but that the cost was considerable. But they also conclude that the programs were poorly targeted, and as much as 78 percent of the benefits were paid for jobs that would have existed even without the program. They call these costs deadweight losses, but we think that they are better interpreted as a transfer to firms' owners.

\section{VI.D. Individual Tax Credits or Grants}

Location-specific tax benefits for individuals are less common spatial policies. The United States does, of course, have significant spatial heterogeneity in state and local tax rates, but these differences are presumably also tied to differences in spending and services. Norway's grants of tax benefits to the residents of its colder, darker, northern climes are an example, but notably these benefits merely subsidize location, not employment or other behaviors.

38. There is compelling evidence that quasi-random increases in property taxes, caused by court-mandated property revaluation, is capitalized into low property values (Yinger and others 1988). Stull and Stull (1991) find evidence for capitalization of differences in local income taxes in the Philadelphia area. 
Intellectually, there would seem to be no reason why places could not be targeted by individual tax benefits as much as firm-specific tax credits, yet there are good reasons why these are less common. The primary beneficiaries of standard tax credits would tend to be richer, rather than poorer, residents, and this makes them poorly targeted for spatially targeted redistribution. Inducing business location in a particular area may achieve agglomeration-related benefits. Inducing people to locate in an area, without associated jobs, would have fewer agglomeration benefits and could potentially make local nonemployment problems worse. The political backlash against place-based individual tax subsidies might be significant.

National tax policy can have important spatial dimensions. Joseph Gyourko and Todd Sinai (2003), for example, show that the benefits of the home mortgage interest deduction accrue to some places more than others. ${ }^{39}$ The 2017 tax law's changes to the deductibility of state and local taxes represents a major spatial policy, essentially benefiting low-tax areas at the expense of high-tax areas.

There are large bodies of literature on both the capitalization and migration effects of differences in state taxes. Wallace Oates (1969) famously reported significant capitalization of tax differences into property values, but the subsequent literature has been far less clear. Jon Bakija and Joel Slemrod (2004) find that the elderly rich move to avoid high estate taxes, but few more general results have been established on tax-based migration.

Federal benefits, such as unemployment insurance and disability insurance, can also be spatially targeted. ${ }^{40}$ Before the 1996 welfare reform, there were significant differences across states in the generosity of the Aid to Families with Dependent Children (AFDC) program. Although the program was nationwide, states could choose their benefit levels, and they paid for part of the benefit.

There is little literature on the capitalization of AFDC differences, but there is a healthy literature on whether these payments induced migration of the poor. Rebecca Blank (1988) found that single-parent families were more likely to leave areas with less generous AFDC payments. George Borjas (1999) argued that the disproportionate flow of immigrants into California reflected its particularly high levels of AFDC payments.

39. Albouy (2010) has argued that the spatial implications of the deduction are helpful in undoing the spatial distortions created by the income tax itself, which deters people from moving to high-income areas.

40. Bartik and Erickcek's (2014) discussion of targeted training programs does not explicitly focus on spatial targeting, but the possibility is clearly implicit in their discussion. 
Though it may be harder to imagine a program that increases nominal payments in some states, programs with constant nominal benefits are the norm, and these benefits have greater value in low-price states. Because government tax dollars go further when local prices are lower, price heterogeneity also gives an added push to spending more in places where costs are lower (Kaplow 1996; Glaeser and Saiz 2004). A ramped-up version of the EITC that provided a uniform hourly work subsidy would have a more disproportionate real impact in lower-income parts of the country.

\section{VI.E. Regulatory Heterogeneity}

The original enterprise zone model also envisioned significant regulatory relief. In practice, these zones were more likely to feature tax relief rather than regulatory relief. In the United States, this reflects the fact that the national government has little power to override local regulations. Globally, there are many prominent examples of zones that offer a special set of rules to businesses. The special economic zones of China, for example, were a powerful example of how business formation can be abetted with freedom from China's robust business controls.

Within the United States, the Devens Enterprise Commission provides a small, local example of a zone with light regulation. When the military base Fort Devens shut down, the Massachusetts state government attempted to encourage business formation in the area with one-stop permitting. The commission claims to have been successful in encouraging new business formation, but there is no academic research documenting its success.

Firms also experience different levels of regulation when they operate in areas that are deemed to be environmentally sensitive. Builders face different regulations when they operate in historic preservation districts. In these cases, historic differences across geography have regulatory consequences that also have an impact on the level of economic activity.

There are also historical accidents that lead to significant regulatory differences. The Channel Islands off the coast of the United Kingdom are not actually part of the United Kingdom or the European Union. Consequently, they operate under a different set of financial regulations, which have made them a hot spot for a variety of financial service firms.

Limiting the supply of new housing restricts migration to particular areas and boosts prices in those areas (Glaeser and Gyourko 2018). We have less evidence on whether other forms of regulation have such effects. Consequently, one of the best justifications for districts with different types of regulations is that they enable experimentation with new types of regulations. For example, entrepreneurship districts that relaxed 
regulations on new businesses would allow one to study the impact of such interventions.

\section{Place-Based Policies for America}

Our theoretical section suggests that public support should shift toward encouraging employment, rather than supporting the not working, in areas where employment responses to earnings are particularly high. Our empirical findings suggest that employment elasticities in some states, like West Virginia, may be much higher than in other states, like Wyoming. Our conclusion is that a policy mix that encourages more employment in high nonemployment states, such as West Virginia, may yield greater benefits than uniform national policies that treat all states equally.

We begin with the two most plausible examples of such place-based actions: targeted location of public activities, and infrastructure investment. We then turn to employment subsidies, which are a natural tool for fighting nonemployment but are harder to target spatially. Finally, we end with education interventions, and prodding community colleges to focus more on employability in regions with high not-working rates.

\section{VII.A. The Location of Public Activity and Infrastructure Investment}

Although there are approximately 22 million public sector workers within the United States, only 2.8 million of them are actually in the federal government. This relatively small employment share necessarily limits the magnitude of any relocation of federal activities. Moreover, 51 percent of civilian, nonpostal workers are either in the military or in veterans' affairs, and consequently, any serious relocation policy would need to focus on the military. ${ }^{41}$

There is mixed evidence on the employment effects of public activity, but the location of military bases does seem to have a positive impact on the local economy (Nakamura and Steinsson 2014). The harder question, which we cannot answer, is What are the costs of the geographic targeting of military spending? Shuttering and reopening the same base somewhere else seems prohibitively expensive. The best opportunities for geographic

41. Spatial targeting could also be done with the much larger set of federal government contractors. Yet imposing added geographic restrictions on contractors would be cumbersome, and would make other objectives, such as supporting minority-owned businesses, more difficult. Moreover, geographic targeting would be quite susceptible to gaming. We suspect that a requirement to use Kentucky-based software providers would lead to relabeling rather than large-scale employment in Kentucky. 
targeting occur at the points of base openings and closings. In principle, new bases can be sited and old bases can be kept open in areas with more elastic employment responses to labor demand.

The most reasonable proposal might be to ask the military to incorporate the effects on local employment into its calculations. If the military actually used a cost-benefit analysis in making location decisions, it would be straightforward to multiply employment effects with estimates of the externalities from employment and incorporate this total location-specific benefit into calculations.

After the military, the Department of Veterans Affairs (VA) is the secondlargest federal employer. The VA has fewer spatially lumped assets, but it does maintain hospitals and large offices. Again, the department could be encouraged to internalize local employment effects when it opens and shuts facilities, but this would be fundamentally limited by the need to match medical facilities with the location of military retirees. The VA's nonmedical employment is more spatially fungible, but represents a modest share of its total employment.

Although the location decisions of the federal government could internalize local employment effects, we are doubtful that such policies could ever be significant in practice. The military will surely oppose any push to have it internalize nonmilitary objectives. The VA will similarly move only with difficulty.

Federally funded infrastructure projects are perhaps the most popular tool for encouraging local economic development. Yet these projects also have a very mixed record of encouraging local employment (Garin 2016), and there is an inherent tension between targeting infrastructure toward growing successful areas that need more infrastructure and supporting distressed areas with a highly elastic labor supply. America's most glaring infrastructure deficits are visible in large, busy, urban areas where airports, like New York's John F. Kennedy International Airport, are undermaintained and where public transportation and highways are highly congested.

If users are willing to pay for both a project's operating and capital costs, then it is unlikely to be a white elephant. If modest federal investment can spur self-financing infrastructure projects in distressed areas, then there seems to be little downside risk. But is there a large number of such potential projects?

The Tennessee Valley Authority was close to being such a project. The original financing for the TVA came from the federal government, but that early investment has been repaid. The TVA also benefited from using eminent domain to move thousands of farmers to gain access to waterways, 
but many of those farmers benefited from subsequent electricity access. The TVA succeeded because it offered a transformative technologyelectricity—for which there was abundant demand.

The Trump administration's infrastructure plan combines a modest amount of federal seed money meant to spur the building of infrastructure that is financed by user fees. The proposal contains tools for scoring prospective proposals, but the details of the scoring algorithm have not yet been made public. The natural means of incorporating concerns about not working into that structure is to provide extra points in the algorithm based on the number of people who can be reasonably projected to find employment as a result of the project after it is completed. Ideally, the social values of these transitions should be denominated in dollars to make them comparable with other criteria used in the scoring algorithm.

If federal investment comes with no expectations for user fee financing, then there is more scope for spatially targeting areas with high not-working rates, and more risk of white elephants. At this point, most legislatively mandated projects do not come with a cost-benefit analysis. If such analyses were to become the norm, then it would be natural to include the social benefits of employment among overall benefits. Even without a cost-benefit analysis, the current Highway Trust Fund apportionment rules could incorporate nonemployment effects. Such alterations to the code would, however, require one to be certain that highway funds spent in areas with high not-working rates do more to reduce not-working rates than highway funds spent in other areas.

In a reformed system with better checks on waste and real cost-benefit analyses, infrastructure could provide a tool for regional support; but without such reforms, the downsides remain significant.

\section{VII.B. Employment Subsidies, Welfare Benefits, and Federal Taxes}

The norm in U.S. politics is that national policies need to be uniform, even when local heterogeneity argues strongly against such uniformity. Housing subsidies, such as the Low Income Housing Tax Credit, treat Detroit, Houston, and San Francisco essentially identically, despite their wildly different housing costs and supply conditions. We have tried to make the case that labor supply elasticities are heterogeneous, and consequently one-size-fits-all employment policies will generate less added employment than spatially differentiated policies. Stronger employment subsidies are likely to reduce joblessness more in eastern Tennessee than in San Francisco.

The current Earned Income Tax Credit is based on annual earnings. It phases in at low incomes, where it essentially offers a proportionate 
increase in earnings; it reaches a maximum value, and for individuals at this earnings threshold it essentially offers a flat nominal subsidy for working; and it phases out at higher incomes, essentially acting as a deterrent on working more.

The EITC can be over $\$ 6,000$ for individuals with three or more children and earnings of about $\$ 16,000$. For individuals who do not have children in their households, it represents an extremely modest work subsidy. However, the overwhelming preponderance of not-working men do not have a child in their homes.

For the EITC to be more effective at spurring prime age male employment, it would need to be more generous to single-person households. One option would be to affect a straight wage subsidy, perhaps administered through employers, which would obviously increase the take-home pay per hour of work. One danger of this approach is that it might engender fraud as workers and firms collude to declare that the worker had labored for longer hours at lower wages. If fraud can be effectively contained, an hourly employer-managed wage subsidy has significant advantages in ease of administration and salience. Any system would need to phase out to be fiscally prudent, which would inevitably deter work. Edmund Phelps (1997) explores the potential implementation of employment subsidies in detail, and proposes a system of employment subsidies based on continuing tax credits for employers.

A flat cash wage subsidy would provide more push in areas with high not-working rates because prices are lower. The current maximum EITC payment, which is fixed in dollar terms, already achieves that end. The phase-in period, which increases earnings proportionally, does not. Consequently, the move to a dollar wage subsidy, instead of a percentage increase, would partially strengthen geographic targeting. A more aggressive approach would increase the size of the wage subsidy in distressed areas, which our estimates suggest would increase employment more per $\$ 1$ spent.

Another approach is to reduce marginal taxes for everyone living in areas with high not-working rates. This approach is embodied in the 2017 tax law, which lowered tax rates for many and increased the standard deduction. But it also severely limited the deductibility of state and local taxes. Effectively, this shift raised taxes in big government states relative to small government states. If local government spending on services like education has significant social value, then this strategy has significant downsides. Yet given the negative correlation between the size of local government and not-working rates, it may also reduce the disincentive to work in areas where not working is more endemic. 
The actual tax code may be less important for deterring employment than the rules surrounding public benefits, like the Supplemental Nutritional Assistance Program, housing vouchers, and disability insurance. These benefits effectively tax employment by decreasing or disappearing entirely with higher earnings. The implicit taxes created by these programs could be reduced in low-employment regions by enabling people who work and earn low incomes to keep more of the benefits. Current implicit tax rates of 30 percent could be reduced to 20 percent, for example.

In this section, we focused on increasing spending in regions with high not-working rates, and we recognize that this could distort migration and lead to high real estate prices. As the theory section made clear, this can be offset if other benefits are removed from the region. We will not analyze appropriate areas to cut; but theoretically, it is possible to reduce nonemployment in regions with high not-working rates while keeping total spending in the region constant and not distorting migration incentives, as long as other nonemployment-enhancing spending is cut back.

Although our model suggests the value of more tailored employment policies, we are notably not calling for local control. Localities often have strong incentives to distort migration in order to attract the rich and repel the poor. Purely local control over social welfare policy could lead to a race to the bottom where states dismantled their safety nets to get rid of their poorer residents.

\section{VII.C. Place-Based Education Reform}

The data strongly support the view that education is an extremely powerful determinant of local success and failure. We consequently join those who see investment in human capital as critical for long-run growth, even if this investment takes a generation or more.

However, education also contains trade-offs between providing skills that maximize future employability and other objectives. Liberal arts education, naturally, has never accepted preprofessionalism, but even in high schools and community colleges there are often diverse objectives. Those trade-offs can be tilted toward employment in regions with high not-working rates.

Currently, the federal government supports community colleges through Pell Grants and other forms of support. This support could be structured to provide incentives that induce those institutions to focus more on jobgenerating skills. For example, community colleges could receive bonus payments for admitting students from distressed regions, who would then be employed for a number of years after graduation. At the least, such a program could be tested for impact. 
We do not anticipate that such incentives will do much in the classroom. It is difficult to change teaching quality for courses such as remedial writing and mathematics. The more likely impact of such an incentive program is that college administrators would begin experimenting with counseling and promoting more employable majors.

Bartik and George Erickcek's (2014) discussion of place-based policies emphasizes the possibility of targeted training programs, which might provide skills that are in high local demand. Though the track record of adult training programs is mixed at best, we agree with Bartik and Erickcek that there is value is experimenting with targeted training. If there are fixed costs to supporting training in particular locations, then it would make sense to have programs disproportionately in areas with a greater need and a more elastic labor supply.

\section{Final Thoughts}

This paper has proposed three plausible justifications for place-based policies: agglomeration economies, geographic targeting of redistribution, and nonemployment reduction in hot spots. The agglomeration case for spatial redistribution is weak, because we know too little about the exact functional form of agglomeration economies. The case for geographic targeting of redistribution is more plausible, but income heterogeneity within areas is much larger than heterogeneity across areas. Moreover, capitalization effects mean that property owners are likely to reap many of the benefits of geographically targeted policies.

The best case for geographic targeting of policies is that $\$ 1$ spent fighting nonemployment in an area with a high not-working rate will do more to reduce nonemployment than $\$ 1$ spent fighting nonemployment in an area with a low not-working rate. The empirical evidence for heterogeneous labor supply responses to demand shocks or public interventions is limited, but is broadly supportive of the view that reducing the notworking rate in some parts of the country is easier than in other parts of the country.

This heterogeneity can either justify added spending in distressed, more elastic areas, or a twist in spending that favors employment in these areas. Though infrastructure remains an important investment for the United States, targeting infrastructure spending toward distressed areas risks producing projects with limited value for users. By contrast, enhanced spending on employment subsidies in areas with extreme joblessness, and perhaps in the United States as a whole, seems like a more plausible means of reducing 
nonemployment. Subsidizing employment seems likely to have a larger impact in the long run if it is matched with investment in work-related human capital.

ACKNOWLEDGMENTS We are grateful to Harris Eppsteiner for outstanding research assistance. For excellent comments, we are very grateful to Gilles Duranton, Robert Hall, and James Stock; to the participants in the Brookings Panel on Economic Activity; and to faculty members of Johns Hopkins University. 


\section{References}

Abraham, Katharine G., and Melissa S. Kearney. 2018. "Explaining the Decline in the U.S. Employment-to-Population Ratio: A Review of the Evidence." Working Paper no. 24333. Cambridge, Mass.: National Bureau of Economic Research.

Ades, Alberto F., and Edward L. Glaeser. 1995. "Trade and Circuses: Explaining Urban Giants." Quarterly Journal of Economics 110, no. 1: 195-227.

Aguiar, Mark, Mark Bils, Kerwin Kofi Charles, and Erik Hurst. 2017. "Leisure Luxuries and the Labor Supply of Young Men." Working Paper no. 23552. Cambridge, Mass.: National Bureau of Economic Research.

Albouy, David. 2010. "Evaluating the Efficiency and Equity of Federal Fiscal Equalization.” Working Paper no. 16144. Cambridge, Mass.: National Bureau of Economic Research.

Alesina, Alberto, Edward Glaeser, and Bruce Sacerdote. 2005. "Work and Leisure in the United States and Europe: Why So Different?" NBER Macroeconomics Annual 20: 1-64.

Alesina, Alberto, Armando Miano, and Stefanie Stantcheva. Forthcoming. "Immigration and Support for Redistribution." Working paper. https://scholar. harvard.edu/stantcheva/publications/immigration-and-support-redistribution

Andersen, Steffen, Glenn W. Harrison, Morten I. Lau, and E. Elisabet Rutström. 2008. "Eliciting Risk and Time Preferences." Econometrica 76, no. 3: 583-618.

Aschauer, David Alan. 1989. "Is Public Expenditure Productive?" Journal of Monetary Economics 23, no. 2: 177-200.

Autor, David H., David Dorn, and Gordon H. Hanson. 2013. "The China Syndrome: Local Labor Market Effects of Import Competition in the United States." American Economic Review 103, no. 6: 2121-68.

Autor, David, David Dorn, Gordon Hanson, and Kaveh Majlesi. 2017. "A Note on the Effect of Rising Trade Exposure on the 2016 Presidential Elections." Working paper. http://www.ddorn.net/papers/ADHM-President2016.pdf

Autor, David H., and Mark G. Duggan. 2003. "The Rise in the Disability Rolls and the Decline in Unemployment." Quarterly Journal of Economics 118, no. 1: 157-206.

Baily, Martin Neil. 1978. "Some Aspects of Optimal Unemployment Insurance." Journal of Public Economics 10, no. 3: 379-402.

Bakija, Jon, and Joel Slemrod. 2004. "Do the Rich Flee from High State Taxes? Evidence from Federal Estate Tax Returns.” Working Paper no. 10645. Cambridge, Mass.: National Bureau of Economic Research.

Barro, Robert J., and Xavier Sala-i-Martin. 1991. "Convergence across States and Regions.” Brookings Papers on Economic Activity, no. 1: 107-82.

Barsky, Robert B., F. Thomas Juster, Miles S. Kimball, and Matthew D. Shapiro. 1997. "Preference Parameters and Behavioral Heterogeneity: An Experimental Approach in the Health and Retirement Study." Quarterly Journal of Economics 112, no. 2: 537-79. 
Bartik, Timothy J. 1991. Who Benefits from State and Local Economic Development Policies? Kalamazoo, Mich.: W. E. Upjohn Institute for Employment Research.

2015. "How Effects of Local Labor Demand Shocks Vary with the Initial Local Unemployment Rate." Growth and Change 46, no. 4: 529-57.

Bartik, Timothy J., and George Erickcek. 2014. "Simulating the Effects of the Tax Credit Program of the Michigan Economic Growth Authority on Job Creation and Fiscal Benefits." Economic Development Quarterly 28, no. 4: 314-27.

Baum-Snow, Nathaniel. 2007. "Did Highways Cause Suburbanization?" Quarterly Journal of Economics 122, no. 2: 775-805.

Baum-Snow, Nathaniel, and Matthew E. Kahn. 2005. "Effects of Urban Rail Transit Expansions: Evidence from Sixteen Cities, 1970-2000." BrookingsWharton Papers on Urban Affairs 6: 147-206.

Berry, Christopher R., and Edward L. Glaeser. 2005. "The Divergence of Human Capital Levels across Cities." Papers in Regional Science 84, no. 3: 407-44.

Betcherman, Gordon, N. Meltem Daysal, and Carmen Pagés. 2010. "Do Employment Subsidies Work? Evidence from Regionally Targeted Subsidies in Turkey." Labour Economics 17, no. 4: 710-22.

Blakely, Tony A., Sunny C. D. Collings, and June Atkinson. 2003. "Unemployment and Suicide: Evidence for a Causal Association?" Journal of Epidemiology \& Community Health 57, no. 8: 594-600.

Blanchard, Olivier Jean, and Lawrence F. Katz. 1992. "Regional Evolutions." Brookings Papers on Economic Activity, no. 1: 1-75.

Blank, Rebecca M. 1988. "The Effect of Welfare and Wage Levels on the Location Decisions of Female-Headed Households." Journal of Urban Economics 24, no. 2: 186-211.

Blundell, Richard, and Thomas MaCurdy. 1999. "Labor Supply: A Review of Alternative Approaches." In Handbook of Labor Economics, Vol. 3A, edited by Orley C. Ashenfelter and David Card. Amsterdam: North-Holland.

Boldin, Michael, and Jonathan H. Wright. 2015. "Weather-Adjusting Economic Data." Brookings Papers on Economic Activity, Fall: 227-60.

Boldrin, Michele, and Fabio Canova. 2001. "Inequality and Convergence in Europe's Regions: Reconsidering European Regional Policies.” Economic Policy 16, no. 32: 206-53.

Bondonio, Daniele, and John Engberg. 2000. "Enterprise Zones and Local Employment: Evidence from the States' Programs." Regional Science and Urban Economics 30, no. 5: 519-49.

Borjas, George J. 1999. "Immigration and Welfare Magnets." Journal of Labor Economics 17, no. 4: 607-37.

Borjas, George J., and Lynette Hilton. 1996. "Immigration and the Welfare State: Immigrant Participation in Means-Tested Entitlement Programs." Quarterly Journal of Economics 111, no. 2: 575-604. 
Boustan, Leah P., and Robert A. Margo. 2013. "A Silver Lining to White Flight? White Suburbanization and African-American Homeownership, 1940-1980." Journal of Urban Economics 78: 71-80.

Braga, Anthony A., Andrew V. Papachristos, and David M. Hureau. 2014. "The Effects of Hot Spots Policing on Crime: An Updated Systematic Review and Meta-Analysis." Justice Quarterly 31, no. 4: 633-63.

Busso, Matias, Jesse Gregory, and Patrick Kline. 2013. "Assessing the Incidence and Efficiency of a Prominent Place Based Policy." American Economic Review 103, no. 2: 897-947.

Butler, Stuart M. 1980. Enterprise Zones: Pioneering in the Inner City. Washington: Heritage Foundation.

Cappelen, Aadne, Fulvio Castellacci, Jan Fagerberg, and Bart Verspagen. 2003. "The Impact of EU Regional Support on Growth and Convergence in the European Union.” Journal of Common Market Studies 41, no. 4: 621-44.

Case, Anne, and Angus Deaton. 2015. "Rising Morbidity and Mortality in Midlife among White Non-Hispanic Americans in the 21st Century." Proceedings of the National Academy of Sciences 112, no. 49: 15078-83.

. 2017. "Mortality and Morbidity in the 21st Century." Brookings Papers on Economic Activity, Spring: 397-443.

Chernobai, Ekaterina, Michael Reibel, and Michael Carney. 2011. "Nonlinear Spatial and Temporal Effects of Highway Construction on House Prices." Journal of Real Estate Finance and Economics 42, no. 3: 348-70.

Chetty, Raj. 2006. “A General Formula for the Optimal Level of Social Insurance.” Journal of Public Economics 90, nos. 10-11: 1879-901.

Chetty, Raj, Adam Guren, Day Manoli, and Andrea Weber. 2013. "Does Indivisible Labor Explain the Difference between Micro and Macro Elasticities? A MetaAnalysis of Extensive Margin Elasticities." NBER Macroeconomics Annual 27: $1-56$.

Chetty, Raj, and Nathaniel Hendren. Forthcoming. "The Impacts of Neighborhoods on Intergenerational Mobility I: Childhood Exposure Effects.” Quarterly Journal of Economics.

Chodorow-Reich, Gabriel. 2017. "Geographic Cross-Sectional Fiscal Multipliers: What Have We Learned?" Working Paper no. 23577. Cambridge, Mass.: National Bureau of Economic Research.

Clark, Andrew E. 2003. "Unemployment as a Social Norm: Psychological Evidence from Panel Data." Journal of Labor Economics 21, no. 2: 323-51.

Clark, Andrew E., and Andrew J. Oswald. 1994. "Unhappiness and Unemployment." Economic Journal 104, no. 424: 648-59.

Clark, Kim B., and Lawrence H. Summers. 1979. "Labor Market Dynamics and Unemployment: A Reconsideration." Brookings Papers on Economic Activity, no. 1: 13-60.

Coglianese, John. 2017. “The Rise of In-and-Outs: Declining Labor Force Participation of Prime Age Men.” Job market paper, Harvard University. https:// scholar.harvard.edu/coglianese/publications/rise-of-in-and-outs 
Cohen, Alma, and Liran Einav. 2007. "Estimating Risk Preferences from Deductible Choice." American Economic Review 97, no. 3: 745-88.

Combes, Pierre-Philippe, Gilles Duranton, and Laurent Gobillon. 2008. "Spatial Wage Disparities: Sorting Matters!” Journal of Urban Economics 63, no. 2: 723-42.

Combes, Pierre-Philippe, Gilles Duranton, Laurent Gobillon, Diego Puga, and Sébastien Roux. 2012. "The Productivity Advantages of Large Cities: Distinguishing Agglomeration from Firm Selection.” Econometrica 80, no. 6: 2543-94.

Conley, Timothy G., and Giorgio Topa. 2002. "Socio-Economic Distance and Spatial Patterns in Unemployment." Journal of Applied Econometrics 17, no. 4: 303-27.

Council of Economic Advisers. 2016. "The Long-Term Decline in Prime-Age Male Labor Force Participation." Washington: White House. https://obama whitehouse.archives.gov/sites/default/files/page/files/20160620_primeage_male_ lfp_cea.pdf

Dall'Erba, Sandy, and Julie Le Gallo. 2007. "The Impact of EU Regional Support on Growth and Employment." Czech Journal of Economics and Finance 57, nos. 7-8: 325-40.

Dao, Mai, Davide Furceri, and Prakash Loungani. 2017. "Regional Labor Market Adjustment in the United States: Trend and Cycle." Review of Economics and Statistics 99, no. 2: 243-57.

Dube, Arindrajit, Ethan Kaplan, and Ben Zipperer. 2015. "Excess Capacity and Heterogeneity in the Fiscal Multiplier: Evidence from the Obama Stimulus Package." Working paper. http://econweb.umd.edu/ kaplan/stimulus_effects.pdf

Duranton, Gilles, and Diego Puga. 2004. "Micro-Foundations of Urban Agglomeration Economies." In Handbook of Regional and Urban Economics, Vol. 4, edited by J. Vernon Henderson and Jacques-François Thisse. Amsterdam: NorthHolland.

Duranton, Gilles, and Matthew A. Turner. 2012. "Urban Growth and Transportation." Review of Economic Studies 79, no. 4: 1407-40.

Eberstadt, Nicholas. 2016. Men without Work: America's Invisible Crisis. West Conshohocken, Pa.: Templeton Press.

Eissa, Nada, and Jeffrey B. Liebman. 1996. "Labor Supply Response to the Earned Income Tax Credit." Quarterly Journal of Economics 111, no. 2: 605-37.

Faggio, Giulia, and Henry Overman. 2014. "The Effect of Public Sector Employment on Local Labour Markets." Journal of Urban Economics 79: 91-107.

French, Eric, and Jae Song. 2014. "The Effect of Disability Insurance Receipt on Labor Supply." American Economic Journal: Economic Policy 6, no. 2: 291-337.

Ganong, Peter, and Daniel Shoag. 2017. "Why Has Regional Income Convergence in the U.S. Declined?" Journal of Urban Economics 102: 76-90.

Garin, Andrew. 2016. "Putting America to Work, Where? The Limits of Infrastructure Construction as a Locally Targeted Employment Policy." Working Paper no. 2016-01. Cambridge, Mass.: Harvard University, Kennedy School of Government, Taubman Center for State and Local Government. 
Glaeser, Edward L., and Joshua D. Gottlieb. 2008. "The Economics of PlaceMaking Policies." Brookings Papers on Economic Activity, Spring: 155-239.

Glaeser, Edward L., Joshua D. Gottlieb, and Oren Ziv. 2016. "Unhappy Cities." Journal of Labor Economics 34, suppl. 2: S129-S182.

Glaeser, Edward, and Joseph Gyourko. 2018. "The Economic Implications of Housing Supply." Journal of Economic Perspectives 32, no. 1: 3-30.

Glaeser, Edward L., and Albert Saiz. 2004. "The Rise of the Skilled City." Brookings-Wharton Papers on Urban Affairs 5: 47-105.

Glaeser, Edward L., and Raven E. Saks. 2006. "Corruption in America." Journal of Public Economics 90, nos. 6-7: 1053-72.

Glaeser, Edward L., and Kristina Tobio. 2008. "The Rise of the Sunbelt.” Southern Economic Journal 74, no. 3: 610-43.

Glaeser, Edward L., and Bryce A. Ward. 2009. "The Causes and Consequences of Land Use Regulation: Evidence from Greater Boston." Journal of Urban Economics 65, no. 3: 265-78.

Goldin, Claudia, and Lawrence F. Katz. 2008. The Race between Education and Technology. Belknap Press.

Goldsmith-Pinkham, Paul, Isaac Sorkin, and Henry Swift. 2018. "Bartik Instruments: What, When, Why, and How." Working Paper no. 24408. Cambridge, Mass.: National Bureau of Economic Research.

Gordon, Robert J. 1973. "The Welfare Cost of Higher Unemployment." Brookings Papers on Economic Activity, no. 1: 133-95.

Gramlich, Edward M. 1994. "Infrastructure Investment: A Review Essay.” Journal of Economic Literature 32, no. 3: 1176-96.

Greenbaum, Robert T., and John B. Engberg. 2004. "The Impact of State Enterprise Zones on Urban Manufacturing Establishments." Journal of Policy Analysis and Management 23, no. 2: 315-39.

Greenstone, Michael, Richard Hornbeck, and Enrico Moretti. 2010. "Identifying Agglomeration Spillovers: Evidence from Winners and Losers of Large Plant Openings." Journal of Political Economy 118, no. 3: 536-98.

Greenwood, Michael J., and Gary L. Hunt. 1984. "Migration and Interregional Employment Redistribution in the United States." American Economic Review 74, no. 5: 957-69.

Gruber, Jonathan. 1997. "The Incidence of Payroll Taxation: Evidence from Chile." Journal of Labor Economics 15, suppl. 3: S72-S101.

Gyourko, Joseph, Albert Saiz, and Anita Summers. 2008. "A New Measure of the Local Regulatory Environment for Housing Markets: The Wharton Residential Land Use Regulatory Index." Urban Studies 45, no. 3: 693-729.

Gyourko, Joseph, and Todd Sinai. 2003. "The Spatial Distribution of HousingRelated Ordinary Income Tax Benefits." Real Estate Economics 31, no. 4: $527-75$.

Hajek, André. 2013. "Life Satisfaction and Unemployment: The Role of Voluntariness and Job Prospects." SOEP Paper on Multidisciplinary Panel Data Research no. 601. Berlin: DIW Berlin. 
Hall, Peter. 1982. "Enterprise Zones: A Justification." International Journal of Urban and Regional Research 6, no. 3: 416-21.

Hall, Robert E. 1972. "Turnover in the Labor Force." Brookings Papers on Economic Activity, no. 3: 709-56.

Ham, John C., Charles Swenson, Ayşe İmrohoroğlu, and Heonjae Song. 2011. "Government Programs Can Improve Local Labor Markets: Evidence from State Enterprise Zones, Federal Empowerment Zones and Federal Enterprise Community." Journal of Public Economics 95, nos. 7-8: 779-97.

Hanson, Andrew. 2009. "Local Employment, Poverty, and Property Value Effects of Geographically Targeted Tax Incentives: An Instrumental Variables Approach.” Regional Science and Urban Economics 39, no. 6: 721-31.

Hausman, Naomi. 2017. "University Innovation and Local Economic Growth." Discussion Paper no. 17.05. Jerusalem: Hebrew University of Jerusalem, Maurice Falk Institute for Economic Research in Israel.

Heckman, James J., and Carmen Pagés. 2004. "Introduction." In Law and Employment: Lessons from Latin America and the Caribbean, edited by James J. Heckman and Carmen Pagés. University of Chicago Press.

Holmes, Thomas J. 1998. "The Effect of State Policies on the Location of Manufacturing: Evidence from State Borders.” Journal of Political Economy 106, no. 4: $667-705$.

Hsieh, Chang-Tai, and Enrico Moretti. 2017. "Housing Constraints and Spatial Misallocation.” Working Paper no. 21154. Cambridge, Mass.: National Bureau of Economic Research.

Johnson, Janna E., and Morris M. Kleiner. 2017. "Is Occupational Licensing a Barrier to Interstate Migration?" Working Paper no. 24107. Cambridge, Mass.: National Bureau of Economic Research.

Juhn, Chinhui, Kevin M. Murphy, and Robert H. Topel. 1991. "Why Has the Natural Rate of Unemployment Increased over Time?" Brookings Papers on Economic Activity, no. 2: 75-142.

Kaplow, Louis. 1996. "The Optimal Supply of Public Goods and the Distortionary Cost of Taxation." National Tax Journal 49, no. 4: 513-33.

Killewald, Alexandra. 2016. "Money, Work, and Marital Stability: Assessing Change in the Gendered Determinants of Divorce." American Sociological Review 81, no. 4: 696-719.

Kleiner, Morris M., and Evgeny Vorotnikov. 2017. "Analyzing Occupational Licensing among the States." Journal of Regulatory Economics 52, no. 2: 132-58.

Kline, Patrick, and Enrico Moretti. 2013. "Local Economic Development, Agglomeration Economies, and the Big Push: 100 Years of Evidence from the Tennessee Valley Authority." Quarterly Journal of Economics 129, no. 1: 275-331.

Kostol, Andreas Ravndal, and Magne Mogstad. 2014. "How Financial Incentives Induce Disability Insurance Recipients to Return to Work." American Economic Review 104, no. 2: 624-55. 
Kposowa, Augustine J. 2001. "Unemployment and Suicide: A Cohort Analysis of Social Factors Predicting Suicide in the US National Longitudinal Mortality Study." Psychological Medicine 31, no. 1: 127-38.

Krueger, Alan B. 2017. "Where Have All the Workers Gone? An Inquiry into the Decline of the U.S. Labor Force Participation Rate." Brookings Papers on Economic Activity, Fall: 1-59.

Krupka, Douglas J., and Douglas S. Noonan. 2009. "Empowerment Zones, Neighborhood Change and Owner-Occupied Housing." Regional Science and Urban Economics 39, no. 4: 386-96.

Lindbeck, Assar, Sten Nyberg, and Jörgen W. Weibull. 1999. "Social Norms and Economic Incentives in the Welfare State." Quarterly Journal of Economics 114, no. 1: 1-35.

Maestas, Nicole, Kathleen J. Mullen, and Alexander Strand. 2013. "Does Disability Insurance Receipt Discourage Work? Using Examiner Assignment to Estimate Causal Effects of SSDI Receipt." American Economic Review 103, no. 5: 1797-829.

Meghir, Costas, and David Phillips. 2010. "Labour Supply and Taxes." In Dimensions of Tax Design: The Mirrlees Review, edited by James Mirrlees, Stuart Adam, Timothy Besley, Richard Blundell, Stephen Bond, Robert Chote, Malcolm Gammie, Paul Johnson, Gareth Myles, and James Poterba. Oxford University Press.

Meyer, Bruce D., and Dan T. Rosenbaum. 2001. "Welfare, the Earned Income Tax Credit, and the Labor Supply of Single Mothers." Quarterly Journal of Economics 116, no. 3: 1063-114.

Miller, Cynthia, Lawrence F. Katz, Gilda Azurdia, Adam Isen, and Caroline Schultz. 2017. "Expanding the Earned Income Tax Credit for Workers without Dependent Children: Interim Findings from the Paycheck Plus Demonstration in New York City." New York: MDRC.

Moretti, Enrico. 2004. "Estimating the Social Return to Higher Education: Evidence from Longitudinal and Repeated Cross-Sectional Data." Journal of Econometrics 121, nos. 1-2: 175-212.

. 2011. "Local Labor Markets." In Handbook of Labor Economics, Vol. 4B, edited by Orley Ashenfelter and David Card. Amsterdam: North-Holland.

Munnell, Alicia H. 1992. "Policy Watch: Infrastructure Investment and Economic Growth." Journal of Economic Perspectives 6, no. 4: 189-98.

Nakamura, Emi, and Jón Steinsson. 2014. "Fiscal Stimulus in a Monetary Union: Evidence from US Regions." American Economic Review 104, no. 3: 753-92.

Neumark, David, and Jed Kolko. 2010. “Do Enterprise Zones Create Jobs? Evidence from California's Enterprise Zone Program." Journal of Urban Economics 68, no. 1: 1-19.

Neumark, David, and William Wascher. 2011. "Does a Higher Minimum Wage Enhance the Effectiveness of the Earned Income Tax Credit?" ILR Review 64, no. 4: 712-46. 
Oates, Wallace E. 1969. “The Effects of Property Taxes and Local Public Spending on Property Values: An Empirical Study of Tax Capitalization and the Tiebout Hypothesis." Journal of Political Economy 77, no. 6: 957-71.

O'Keefe, Suzanne. 2004. “Job Creation in California's Enterprise Zones: A Comparison Using a Propensity Score Matching Model.” Journal of Urban Economics 55, no. 1: 131-50.

Papke, Leslie E. 1994. "Tax Policy and Urban Development: Evidence from the Indiana Enterprise Zone Program." Journal of Public Economics 54, no. 1: 37-49.

Phelps, Edmund S. 1997. Rewarding Work: How to Restore Participation and SelfSupport to Free Enterprise. Harvard University Press.

Platt, Stephen. 1984. "Unemployment and Suicidal Behaviour: A Review of the Literature." Social Science \& Medicine 19, no. 2: 93-115.

Rauch, James E. 1993. "Productivity Gains from Geographic Concentration of Human Capital: Evidence from the Cities." Journal of Urban Economics 34, no. 3: 380-400.

Rivera Drew, Julia A., Sarah Flood, and John Robert Warren. 2014. "Making Full Use of the Longitudinal Design of the Current Population Survey: Methods for Linking Records across 16 Months." Journal of Economic and Social Measurement 39, no. 3: 121-44.

Rothstein, Jesse. 2010. "Is the EITC as Good as an NIT? Conditional Cash Transfers and Tax Incidence.” American Economic Journal: Economic Policy 2, no. 1: 177-208.

Rubin, Barry M., and Craig M. Richards. 1992. "A Transatlantic Comparison of Enterprise Zone Impacts: The British and American Experience." Economic Development Quarterly 6, no. 4: 431-43.

Schleicher, David. 2017. "Stuck! The Law and Economics of Residential Stagnation." Yale Law Journal 127, no. 1: 78-154.

Smith, James P., and Finis R. Welch. 1989. "Black Economic Progress after Myrdal." Journal of Economic Literature 27, no. 2: 519-64.

Stull, William J., and Judith C. Stull. 1991. "Capitalization of Local Income Taxes." Journal of Urban Economics 29, no. 2: 182-90.

Topa, Giorgio. 2001. "Social Interactions, Local Spillovers and Unemployment." Review of Economic Studies 68, no. 2: 261-95.

Wilder, Margaret G., and Barry M. Rubin. 1996. "Rhetoric versus Reality: A Review of Studies on State Enterprise Zone Programs." Journal of the American Planning Association 62, no. 4: 473-91.

Winkelmann, Rainer. 2014. "Unemployment and Happiness." World of Labor no. 94. Bonn: Institute for the Study of Labor (IZA).

Yinger, John, Howard S. Bloom, Axel Börsch-Supan, and Helen F. Ladd. 1988. Property Taxes and House Values: The Theory and Estimation of Intrajurisdictional Property Tax Capitalization. Boston: Academic Press.

Zabek, Mike. 2018. "Local Ties in Spatial Equilibrium.” Job market paper, University of Michigan. https://mikezabek.com/pdf/LocalTies.pdf 


\section{Comments and Discussion}

\section{COMMENT BY}

GILLES DURANTON To appreciate the contribution of this paper by Benjamin Austin, Edward Glaeser, and Larry Summers and some of its strengths and limitations, it is useful to start with a bit of intellectual history. The vast majority of economists hold negative views about placebased policies. For instance, in their review chapter in the recent Handbook of Regional and Urban Economics, David Neumark and Helen Simpson (2015, p. 1279) reach a mostly negative conclusion:

In our view, a major shortcoming of the research on place-based policies is that even the most positive evidence on their effectiveness does not establish that they create self-sustaining economic gains. That is, at best, the evidence (sometimes) says that when place-based incentives are in effect, there are increases in economic activity and perhaps welfare.

In an older essay published in the Brookings Papers, Glaeser and Joshua Gottlieb (2008) also conclude negatively. They argue that the efficiency case for relocating economic activity relies on assumptions for which empirical support is lacking, while equity objectives could be achieved at much lower costs, using more direct instruments.

Although I believe that the conclusions of Neumark and Simpson (2015) and Glaeser and Gottlieb (2008) appropriately reflect what we know, they overlook two fundamental elements. The first is that many public goods are lumpy and need to be located somewhere. In many circumstances, spatial choices simply cannot be avoided. This dimension is particularly, but not only, salient for infrastructure. The second overlooked element is that countries, including the United States (or perhaps especially the United States) are far from homogeneous. The response to policy changes, from setting interest rates to providing unemployment benefits, will potentially differ across regions. One policy size will not fit all. Hence, a good case can 
be made that policies should differ across the regions of a country. These two elements suggest that economists, who have been rightfully wary of the hubristic nature of many place-based policies, may have thrown the baby of spatial differentiation out with the bathwater of egregious past place-based policies.

With this in mind, the first great merit of this paper is to bring regional issues back onto the agenda and provide a more balanced look at them, acknowledging and providing evidence for the fact that the fundamentals of the economies of U.S. regions differ and that these differences potentially call for spatially differentiated policies. More specifically, the main claim made in the paper is unemployment and withdrawal from the labor market - the "lack of jobs"-is the outcome of labor market fundamentals that vary across places. These differences call for different policy responses, including more generosity for unemployment benefits and perhaps jobs subsidies in a group of noncoastal states east of the Mississippi River that they call the eastern heartland. This is the second merit of this paper. It sticks its head out and makes a fairly concrete set of proposals.

To structure the rest of this discussion, I rely on my recent research with Anthony Venables (Duranton and Venables 2018), which we prepared for the World Bank to provide guidelines for place-based policies and infrastructure investments in developing countries. Before going any further, a number of comments are in order. Quite obviously, the eastern heartland's problems differ quite considerably from those of lagging regions in Africa or even South America. This difference is, however, one of degree but not nature. The seven principles that I use below are general enough that they should apply to place-based policies in the United States, including the proposals made by Austin, Glaeser, and Summers. A more serious caveat is that my discussion below might be taking the authors' proposal more seriously than they themselves intended. Related to this, the seven principles that I use in this comment to assess the authors' proposal are extremely demanding. I argue that the authors go a long way toward answering these demands, but a full set of answers would go beyond what a single paper can achieve, and should be the object of an entire research agenda. The gaps that I highlight should thus be seen as requests for further research rather than shortcomings of the present paper.

PRINCIPLE 1: PROVIDE A NARRATIVE AND A THEORY OF THE PROBLEM Any policy proposal should state clearly what the main problem is and why market forces are not effective in solving it. In other words, there must be an externality or a source of inefficiency, which the proposed policy will tackle. This may seem obvious enough, and perhaps should go without 
saying. Unfortunately, the economic policy world is replete with solutions in search of a problem. This said, it is also perfectly fine to justify an intervention on equity grounds, but this should be made clear. To satisfy this first requirement, the policy proposal need not, and should not, be highly formal at this stage. It should really be about stating the first-order issues. This step is sometimes referred to as the strategic case for a policy, but it must go beyond a statement of good intentions.

Among the seven principles considered here, this is one (of two) where I think the paper is lacking. To avoid any misunderstanding on why this is, it is important to go into some details regarding the paper's content. First, it is true that Austin, Glaeser, and Summers propose a rich description of the symptoms. They document the economic malaise of the eastern heartland very powerfully by focusing on the fraction of prime age adults who are not at work. The facts are clearly alarming, and the authors make a great case that this comes at extremely high welfare costs. I applaud this, and this is not what my grudge is about.

The paper also offers rich theories of the possible solutions to the economic malaise of the eastern heartland. In particular, the authors convincingly show that offering direct economic or fiscal incentives to redistribute economic activity across locations is highly likely to be misguided. These theories of the solutions are useful and important because we need to know what the proposed medicine will do and what its side effects might be. To give a simple example that is developed at length in the paper, bringing economic activity to a place may just make housing more expensive and offset most (or even all) of the wage gains created by the policy for the targeted residents. These are important points, which are all too often neglected, but this is not where I have a problem with the paper.

My problem with the paper is actually as follows. To continue with medical analogies, consider a patient suffering from acute fever, headaches, nausea, and muscle pain. This could be the flu, meningitis, or something else. Appropriate treatment of the patient requires knowing what is behind the symptoms. The same holds here. Different types of market failures may lead to the same suboptimal outcomes in a lack of jobs, but these various failures will in general require very different solutions.

Taken literally, the paper argues that optimal social insurance depends on a number of parameters that vary across regions. Thinking about missing insurance markets is important, but raises several problems. First, the optimal social insurance approach is not sufficiently contextualized in the paper, and it is unclear what the risks really are and what risk aversion is really about. Robert Hall, in his comment, dwells at length on this important 
point. Second, while framing its policy proposal narrowly as optimal social insurance that varies across regions, the paper also implicitly blames "insufficient" labor market demand in some parts of the country. What is the inefficiency here? What do we mean by insufficient demand? Beyond this, how do we know that the problem, whatever it might be, is really on the demand side? A reasonable prima facie case can be made that at least part of the lack of jobs may be due to the supply side of the labor market. Simply put, is the opioid epidemic a cause or a consequence of the eastern heartland's woes? We also need to know more about the problem's geography. Is this a regional issue, as Austin, Glaeser, and Summers argue; or does something more widespread afflict rural and small-town America? In the latter case, it may be still particularly salient in the eastern heartland, which has only two large metropolitan areas, Detroit being one of them. Although the outcomes may be the same, this would call for a very different form of spatial targeting.

I really hope future research will get to the bottom of this. A good theory of the problem can be disproved in a way that a vague assertion that there is a crisis cannot be.

PRINCIPLE 2: ASSESS THE QUANTITY CHANGES AND SEPARATE DIRECT FROM INDIRECT EFFECTS After stating the strategic case and the problems that will be solved by the proposed policy, the next step toward an ex ante evaluation of a place-based policy is to start quantifying its expected effects. The first part of this exercise is to assess what the policy proposal will do to the quantities of employed labor, output, housing, and so on. More specifically, the question is, How much change will a project generate relative to business as usual? A key feature of place-based policies is that they have both direct effects (user benefits) and indirect effects (spillovers). A transportation improvement somewhere will lead to reductions in transportation time or costs. It may also induce employment generation, some of which may come at the expense of other areas. A good assessment of quantity changes is perhaps the hardest step for any cost-benefit analysis, because a good measure of additionality requires being able to predict not only what will happen in the treated area but also what will not happen in areas that are not treated.

The paper actually scores highly on this dimension. Austin, Glaeser, and Summers conduct three different exercises. In the first one, they perform an analysis of Bartik shocks. This captures both direct and indirect effects, and they find good evidence of stronger effects in areas with fewer jobs. I only have two minor quibbles here. It is unclear to me how labor demand shocks quantitatively map into wage subsidies. It would also be 
useful to obtain a breakdown between the direct effects and the attendant economic (or perhaps social) multipliers.

In the second exercise, the authors look at the literature on the heterogeneous effects of social programs. This literature review appears inconclusive. In their third and final exercise, they execute a Nakamura-Steinsson exercise to gauge the local effects of increased public spending (Nakamura and Steinsson 2014). Unfortunately, this exercise is again inconclusive. The authors should be lauded for their thoroughness and their transparency. I also greatly appreciate the fact that they discuss similar experiences in other countries, European countries in particular. There is no point trying to reinvent the wheel, and there is much to learn from what other countries have done.

PRINCIPLE 3: VALUE THE QUANTITY CHANGES Making a prediction about how a place-based policy is going to affect the situation is only half the quantification. The next important step is to value the changes that will be brought about by the policy. In a world that is efficient ("competitive," in the jargon of economists), one may change quantities through an intervention, but that does not create social value, because quantity changes are worth nothing at a competitive equilibrium. The competitive price reflects both consumers' willingness to pay and the social marginal cost of production. For a quantity change to be of value, we need a wedge between private and social values. In turn, this wedge should be the one described in the strategic case for the place-based policy, as per my first principle above.

The paper again performs very well on this key aspect. The valuation formula proposed by Austin, Glaeser, and Summers is in the Baily-Chetty tradition (Baily 1978; Chetty 2006). It contains five fundamental terms: (i) a fiscal value of employment, (ii) a social value of employment, (iii) a value of nonemployment, (iv) an elasticity of labor supply, and (v) a coefficient of relative risk aversion. Although I wish they had connected their empirical analysis more strongly to this valuation formula, the authors do exemplary work. Some of these parameters, like the coefficient of relative risk aversion, are the subject of a large body of literature (and also have much uncertainty, unfortunately). There, the authors do their best to find what they think are the most relevant available estimates, and they are very transparent about the relevant range that needs to be considered. For the values of being at work versus not being at work, Austin, Glaeser, and Summers consider a large amount of data, from which they distill key magnitudes. These magnitudes seem broadly right to me. Finally, for labor supply elasticity, they rely on both a large body of literature in labor economics for general guidance and on their own original empirical work, 
because the specific issue of differences across regions has not received much attention.

Having looked at many policy proposals and evaluations, this one clearly stands out with its seriousness. Again, this is not an exact calculation. Whether the social loss of not working corresponds to 36.3 percent of the typical unskilled wage certainly warrants further research, just as with the estimation of regional differences in labor supply elasticity. These are quibbles, which obviously are important, but quibbles nonetheless, if we believe the numbers are in the right ballpark.

The less obvious but more important issue is again whether these regional differences are true regional differences or can be tracked to something else, such as a rural and small town versus metropolitan differences, or to some particular sectors that are overrepresented in some regions. The former explanation would call for a different type of place-based differentiation, while the second would call for radically different policies to be implemented at the sector level. More generally, this brings us back to a need for a strong theory of the problem and for explanations of why the labor market has changed the way it has in different parts of the United States.

PRINCIPLE 4: PROVIDE TRANSPARENT REDUCED-FORM CALCULATIONS Though we need a detailed set of calculations for a full cost-benefit assessment, we also need to know from simplified calculations where the key magnitudes are coming from. This is an important sanity check. It is easy to fool readers (or oneself, in the case of honest mistakes) when dealing with pages and pages of numbers that are intricately related. It is much harder to fool knowledgeable readers when applying a simple formula with just a few terms.

This point does not call for a long discussion here. The paper does very well on this dimension. Though the writing could be at times clearer, all the quantifications are performed, and all the cards are put on the table to let the reader judge.

PRINCIPLE 5: PROVIDE A SENSITIVITY ANALYSIS AND BUILD SCENARIOS Another reasonable requirement for any policy proposal is to know what it is sensitive to and what it is insensitive to. Perhaps more subtle (but equally warranted, in my eyes) is the notion that we need to know under what set of circumstances a policy would be badly off. Sometimes, not a single failure but a conjunction of mistakes and events leads to a total policy nightmare. It is important to know what these might be.

Here, the paper does fine on the first subpoint but could be better on the second. For all the parameters for which there is much uncertainty, the 
authors provide useful and relevant sensitivity assessments. They could have done more on the second aspect and have fleshed out the worst-case scenarios. But this is a minor quibble, and I understand that the paper had length limits.

PRINCIPLE 6: DESCRIBE THE NEEDED COMPLEMENTARY POLICIES LOcal complementarities are really the fundamental justification for place-based policies. Austin, Glaeser, and Summers understand this perfectly, and their key piece of evidence is that labor demand shocks have a bigger effect in places where a smaller proportion of prime age workers are actually at work. In turn, local complementarities often call for multiple interventions. In our situation here, labor demand stimulations may be coupled with remediation policies on the labor supply side. Education is an obvious suspect here, and the authors give it some thought. Beyond education, training and retooling should be given further consideration (Hyman 2018).

PRINCIPLE 7: ANALYZE ALTERNATIVE POLICY PROPOSALS TO ACHIEVE THE SAME OBJECTIVE Although the second and third principles for place-based policies are about showing that a project represents an improvement over business as usual, my last principle is that any project should make the case that the same objectives could not be achieved at a lower cost.

Here, I find the paper wanting. Before going deeper, let me provide two caveats to my criticism. First, the authors do acknowledge and understand the difficulties associated with direct unemployment subsidies, and they discuss less direct approaches, such as infrastructure provision. Second, full compliance with this last principle would go well beyond a single paper, because it would require making progress on core questions of regional development that have vexed research for at least 25 years.

This said, a key limitation of the approach taken by Austin, Glaeser, and Summers is that factors are essentially treated as immobile. When factor mobility-migration, in particular-is discussed in the paper, it is only viewed as a source of complications for their proposed policy. In essence, the authors rightfully argue that labor mobility may crowd out gains from a better spatial targeting of job subsidies. However, factor mobility is not only a complication for what the authors propose; it may also be a big part of an alternative solution.

Going back to the work of Olivier Blanchard and Lawrence Katz (1992), a strong case can be made that labor mobility is a key mechanism that pushes toward regional equalization. My recent rereading of the literature on this subject suggests that it may even be the only real driver of regional convergence (Duranton and Venables 2018). The steep decline 
of labor mobility in the United States during the last 20 years is certainly worrisome. Whether this margin can be fixed at a reasonable cost should be high on our priority list.

\section{REFERENCES FOR THE DURANTON COMMENT}

Baily, Martin Neil. 1978. "Some Aspects of Optimal Unemployment Insurance." Journal of Public Economics 10, no. 3: 379-402.

Blanchard, Olivier Jean, and Lawrence F. Katz. 1992. "Regional Evolutions." Brooking Papers on Economic Activity, no. 1: 1-75.

Chetty, Raj. 2006. "A General Formula for the Optimal Level of Social Insurance." Journal of Public Economics 90, nos. 10-11: 1879-901.

Duranton, Gilles, and Anthony J. Venables. 2018. "Place-Based Policies for Development." Policy Research Working Paper no. 8410. Washington: World Bank.

Glaeser, Edward L., and Joshua D. Gottlieb. 2008. "The Economics of Place-Making Policies." Brookings Papers on Economic Activity, Spring: 155-239.

Hyman, Ben. 2018. "Can Displaced Labor Be Retrained? Evidence from QuasiRandom Assignment to Trade Adjustment Assistance." Job market paper, University of Pennsylvania. https://www.benhyman.com/research-1/

Nakamura, Emi, and Jón Steinsson. 2014. "Fiscal Stimulus in a Monetary Union: Evidence from US Regions." American Economic Review 104, no. 3: 753-92.

Neumark, David, and Helen Simpson. 2015. "Place-Based Policies." In Handbook of Regional and Urban Economics, Volume 5, edited by Gilles J. Duranton, J. Vernon Henderson, and William C. Strange. Amsterdam: North-Holland.

\section{COMMENT BY}

ROBERT E. HALL This paper by Benjamin Austin, Edward Glaeser, and Larry Summers begins by thoroughly documenting a disturbing trend in the United States: the decline in employment in the heartland among men in an age group that generally had employment rates above 90 percent in a previous era. Social pathologies, notably, a high mortality rate and opioid abuse, are more common in the heartland. The paper then engages in ambitious calculations of the social benefits of corrective policies that would improve insurance against forces causing persistent employment fluctuations and would subsidize employment to take advantage of favorable externalities resulting from employment increases.

Resisting intense pressure from me, the authors sometimes use the word joblessness to refer to nonwork. A consistent dogma of the paper is that unemployment —often termed "joblessness" by other authors-is not a useful category for thinking about the issues in the paper. The authors write, "We take the view that the distinction between unemployment and labor 
force nonparticipation . . . is relatively arbitrary because almost all the nonemployed would presumably work if the price were right." Although I agree that the employment-to-population ratio is sometimes a useful metric for judging labor market performance, I believe that there is a real difference between men classified as out of the labor force and those classified as unemployed. It is definitely not the case that unemployment is measured by asking people if they want a job. Rather, in the Current Population Survey, respondents are asked about their work in the past week and their active job searches in the past 4 weeks. The criterion for classifying a person as unemployed is: no work but an active search. Dreaming about unrealistic wages is not part of the process.

Christopher Flinn and James Heckman (1983) provided the theoretical foundation for modern thinking about defining and measuring unemployment. They concluded that the reasonable way to divide the nonemployed population into the unemployed and those not in the labor force is according to their predicted job-finding probabilities. The Current Population Survey's criterion does a good job of distinguishing unemployment from those not in the labor force. In a recent paper published in the American Economic Journal: Macroeconomics, Sam Schulhofer-Wohl and I fit equations to data on job-finding rates as contemplated by Flinn and Heckman (Hall and Schulhofer-Wohl 2018). My table 1 shows the results-the predicted probability that various categories of nonworkers will be employed 12 months after they are surveyed. In the first line of the table, people who are not searching and say they do not want a job or are not available to work are shown to have a small, 11 percent probability of actually starting a job in the coming year. In the second line of the table, people who are not searching but do want a job and are available have a higher, 32 percent predicted probability. These two groups are not counted in the standard unemployment measure, but all those on the second line and some from the first line are included in the Bureau of Labor Statistics' alternative, more inclusive labor force underutilization rates. The remaining lines in the table show that people counted as unemployed have probabilities ranging from 42 percent (the long-term unemployed) to 67 percent (those recently laid off). Based on these results, the reasonable conclusion is that the Bureau of Labor Statistics uses the Flinn-Heckman approach, with a cutoff probability of something like 37 percent. The results also strongly confirm the hypothesis that unemployment is a real phenomenon, capable of measurement in a survey, not based on daydreaming.

Austin, Glaeser, and Summers deal with a group of men termed not employed. The criterion for inclusion in the study is that the man is not 
Table 1. The Probability That a Nonemployed Person Will Hold a Job in the Next Year

\begin{tabular}{lc}
\hline Initial worker classification & Percent \\
\hline Counted as not unemployed & \\
Does not want a job or is not available to work & 11 \\
Wants a job and is available to work but is not searching for a job & 32 \\
Counted as unemployed & \\
Was recently laid off & 67 \\
Recently lost a permanent job & 66 \\
Temporary job recently ended & 62 \\
Recently quit a job & 65 \\
Recently entered the labor force for the first time & 45 \\
Recently reentered the labor force & 50 \\
Was laid off months ago & 59 \\
Lost permanent job months ago & 60 \\
Temporary job ended months ago & 54 \\
Quit a job months ago & 58 \\
Entered the labor force for the first time months ago & 44 \\
Reentered the labor force months ago & 46 \\
Is long-term unemployed & 42 \\
\hline
\end{tabular}

Source: Hall and Schulhofer-Wohl (2018).

employed at the time of the survey. These nonemployed men are broken down into two dramatically different groups, those I call short-termers, who had some employment in the past year, and long-termers, who had none. There is persuasive evidence that the short-termers are really different from the long-termers. The best evidence appears in the authors' table 6. The table shows that short-termers earned 54 percent as much as those employed at the time of the survey, so the short-termers are quite involved in work-for one reason or another, they were looking for work, in school, sick, or taking a break for about half the year but were working the other half. The authors' table 6 is also particularly telling about the fairly close connection of the short-termers to the labor market and the disconnect of the long-termers from the market: 61 percent of the cash benefits received by the short-termers came from unemployment insurance, whereas 73 percent of cash benefits received by longtermers came from disability. In general, I find the information about the long-termers much more relevant to the topics of the paper than the information about the short-termers. But a good deal of the paper lumps the two groups together, somewhat blurring the paper's key messages.

The authors' fans hoped for a daring and interesting, even if less-thandefinitive, measure of the social benefit of place-based policies to draw 
men back into employment. And they got what they hoped for. The key calculation the fans were waiting for appears in the paper as solving

$$
\left(\frac{w_{0}+e}{w_{0}}\right)^{-\gamma}=1+\left(\frac{e}{w_{0}}-\frac{b+k}{w}\right) \varepsilon
$$

for the optimal wage subsidy $e / w_{0}$, given three key inputs: (i) a preference curvature parameter, $\gamma$; (ii) a measure of the positive externality of employment, $(b+k) / w$; and (iii) the overall elasticity of labor supply, $\varepsilon$, combining the effect of the wage on a given man's choice to work and the distribution of the propensity to work across the population.

What is $\gamma$ ? The paper calibrates this key participation parameter to the coefficient of relative risk aversion. But the model deals with neither risk nor intertemporal substitution. Rather, the model says that the wage $w^{*}$ at which a man is indifferent between working and not working is the solution to

$$
\frac{w^{* 1-\gamma}}{1-\gamma}=\frac{d^{1-\gamma}}{1-\gamma}+c
$$

where $d$ is the amount of consumption (or equivalent) when not working and $c$ is the utility disamenity of working. Estimation of $\gamma$ is a standard random-utility problem - a probit if $c$ is $\log$-normal—but requires data on the participation decisions of men with known values of $d$.

As the authors' figure 20 shows, the assumed value of $\gamma$ has first-order effects on the results of the model. Absent information about $\gamma$, the authors are unable to interpret the findings of the labor supply estimation-they cannot separate the effects of the distribution of the unobserved variable $c$ from the elasticity of $w^{*}$ for a man with given $c$. Thus, the results of the paper are more indicative than dispositive. But they certainly point in a constructive direction for more work.

Another key input is quantification of the employment externality. The authors assume that the nonhousing spending reduction enjoyed by parents, when a man previously living off his parents becomes employed, is an externality gained by the parents. The measure of this spending is the actual nonhousing spending of men who do not live with their parents, 15 percent of earnings. Another externality is the decline in government benefits and the increase in taxes that occurs when a man previously out of the labor market gets a job, taken to be 21 percent of earnings. Thus, $(b+k) w=0.363$. 
The other key input is the elasticity of the overall labor supply function. Here, the authors rely on the Bartik identification scheme. Everybody using Bartik (that is, 93 percent of the empirical macroeconomics profession) should study "Bartik Instruments: What, When, Why, and How," by Paul Goldsmith-Pinkham, Isaac Sorkin, and Henry Swift (2018). Austin, Glaeser, and Summers cite this paper and their conclusion, "Identification is dependent on the exogeneity of initial industry shares," but they do not go on to argue why they expect this condition to hold. Again, there is more to do on this project.

The authors have produced a highly informative paper on a key subject. It should lead to a raft of interesting follow-up research. In my opinion, it would have been even better if it had not included the short-term nonworkers and if it had focused just on the long-term ones, who are truly out of the labor force. But the paper delivered most of what the fans were hoping for.

\section{REFERENCES FOR THE HALL COMMENT}

Flinn, Christopher J., and James J. Heckman. 1983. “Are Unemployment and Out of the Labor Force Behaviorally Distinct Labor Force States?" Journal of Labor Economics 1, no. 1: 28-42.

Goldsmith-Pinkham, Paul, Isaac Sorkin, and Henry Swift. 2018. "Bartik Instruments: What, When, Why, and How." Working Paper no. 24408. Cambridge, Mass.: National Bureau of Economic Research.

Hall, Robert E., and Sam Schulhofer-Wohl. 2018. "Measuring Job-Finding Rates and Matching Efficiency with Heterogeneous Job-Seekers." American Economic Journal: Macroeconomics 10, no. 1: 1-32.

GENERAL DISCUSSION Olivier Blanchard stated that in order to know which place-based policies should be employed, one needs to know whether there is a labor supply or labor demand issue. In this context, he argued that there is clearly a labor supply problem in relation to opioid users. This raises the question of hysteresis - that is, were they opioid users to begin with, or did they become users because they were not employed? He wondered if there was any evidence in the literature on the causal relationship between unemployment and opioid use. Are opioids something people turn to only when times are tough, or is opioid use more widespread?

Alice Rivlin welcomed the authors' focus on place-based policies. There are areas of the United States where the economy is not working well, and in the long run it is not sustainable for coastal economies to be working well while other areas are not. However, when she initially read "place-based 
policies," she had expected something different. She would not classify most of the policies the authors discuss as place-based policies, but rather as individual-based policies that vary depending on where one lives. According to Rivlin, a true place-based policy would need to take into account the reasons why the place is in trouble and what can be done about it. The distressed areas highlighted by the authors have deep structural issues that will not be cured simply by giving people more of an incentive to find jobs. The United States has experimented with several place-based policies, and the ones that have worked — and most have not—have engaged the whole community, including educational, business, and political stakeholders; there needs to be an economic basis other than the industry that moved out. This inevitably leads to the "the thing that economists have always deplored"- the triage problem, whereby the government needs to choose where to channel the money.

Hilary Hoynes pushed back on the authors' objections to the national uniformity of the Earned Income Tax Credit and Supplemental Nutrition Assistance Program. The authors assert that because these programs are nationally uniform, it follows that they are not well equipped to deal with spatial heterogeneity. But it is important to note that though they do not vary in nominal terms across space, significant regional price differences imply that they do vary in real terms across space. She suggested that it might be worth thinking about whether these programs look more favorable when adjusted for local prices.

Tracy Gordon underscored the points made by Hoynes. Even though there are problems with place-based strategies, the fact that the federal income tax code and safety net programs are not indexed for regional costs of living already provides an effective implicitly place-based policy. In addition, the federal government provides grants to state and local governments, beyond payments to individuals, and these grants have almost no correlation with local fiscal capacity. The American Recovery and Reinvestment Act, for instance, provided an incremental increase in Medicaid grants that was tied to local unemployment. Such place-based policies might still be effective instruments today.

$\mathrm{N}$. Gregory Mankiw noted that there is a sizable body of literature showing that women have larger labor supply elasticities than men, which suggests that women face lower marginal tax rates than men. ${ }^{1}$ Thus, a standard

1. Alberto Alesina, Andrea Ichino, and Loukas Karabarbounis, "Gender-Based Taxation and the Division of Family Chores," American Economic Journal: Economic Policy 3, no. 2 (2011): 1-40. 
utilitarian framework for tax analysis would suggest that different tax codes should be applied to women and men. ${ }^{2}$ The present paper conducts a similar exercise, because it separates two geographically different types of people with different elasticities and suggests that different policies should be applied to them. Mankiw asked why one should feel uncomfortable dividing people up in many different ways and estimating different elasticities. There are several possible reasons. One reason is the philosophical argument regarding equal protection; just as it is not right that men and women have different tax codes applied to them, some people might object to the notion of different states having different safety nets apply to them. There is also a political economy component; it is hard to imagine Congress saying that it is optimal for every person to have a different policy depending on their individual characteristics.

Jason Furman reiterated Mankiw's point about the political economy objections to place-based policies. If he were asked before the authors' presentation what his views were on place-based policies, he would have cited Glaeser's own mantra, People, not places. ${ }^{3}$ And unless Glaeser and Summers were personally in charge of implementing place-based policies, Furman would still say People, not places. Although the authors discussed nearly all the economic objections to place-based policies, they neglected the political economy objections. Furman noted three that he thought were most difficult to overcome.

The first objection is how to choose the places to target. The authors ran a simple model to show which places would benefit from a particular policy, but for other policies it is hard to know where they should be targeted. Should policies be targeted at poor areas or wealthy areas? Should they be targeted at rising areas to encourage the rise, or at falling areas to reverse the fall? During his time in the Obama administration, Furman spent a lot of time trying to figure out which places should be targeted as opportunity zones. "I threw up my hands, I couldn't figure out how to do it," Furman admitted.

Furman's second objection was that once a place is selected, it tends to remain in the program forever. The Clinton administration selected "empowerment zones" in the early 1990s. Even if they were picked per-

2. N. Gregory Mankiw and Matthew Weinzierl, "The Optimal Taxation of Height: A Case Study of Utilitarian Income Redistribution," American Economic Journal: Economic Policy 2, no. 1: 155-76.

3. Edward Glaeser, "Where Edwards Is Right," New York Sun, August 7, 2007. 
fectly, the notion that these same places-which are still empowerment zones today-make sense 30 years later is not plausible, Furman argued.

Finally, place-based policies are often stoked up as having been more effective than they actually were. Policymakers could expand the Earned Income Tax Credit or the Child Tax Credit to help 10 million people; but a $\$ 10$ million grant to one place could be more politically rewarding. Placebased policies, once implemented, tend to help a small number of people, but they are tangible things that policymakers can feel good about. None of Furman's objections have any bearing on whether place-based policies are good ideas economically; but in order to pass political economy muster, the economic benefits need to outweigh the political risks.

Kent Smetters wondered how much evidence for the local Phillips curve actually reflects existing government policy, especially about policies that encourage middle-class and lower-income people to get housing. In Detroit, for example, there was a negative shock, and many people's mortgages went underwater, and as a result they could not easily move because they had to pay rent or pay off their mortgage. He wondered to what extent existing policy factors into this. He also wondered, when it comes to normative judgments, how much is current bias in our thinking about these issues. It is easy, for example, to discuss everything great about today's Detroit, such as the Tigers and the Pistons; but if one could go back in time and "save Dodge City," would it have been the right policy to keep propping up that Detroit? The effects of externalities and networks on labor markets cut both ways, in that there are multiple equilibria-both good and bad. Government policy could be enforcing the bad equilibrium. The optimal policy, in Smetters's view, is not necessarily to keep the Dodge Cities around, but rather to think about how to reduce tipping points and how to make mobility more effective.

John Haltiwanger suggested thinking about other potential covariates of the spatial variation of the employment-to-population ratio. For example, a Spring 2016 Brookings Paper by Raven Molloy and coauthors documented the decline in interstate migrations and its close ties to declines in broader measures of labor market fluidity, worker reallocation, job reallocation, and job-to-job hopping rates. ${ }^{4}$ In that paper, and also in work by Haltiwanger and Steven Davis, the authors point out that the decline in the

4. Raven Molloy, Christopher L. Smith, Riccardo Trezzi, and Abigail Wozniak, "Understanding Declining Fluidity in the U.S. Labor Market," Brookings Papers on Economic Activity, Spring 2016: 183-237. 
employment-to-population ratio for men is especially concentrated among the less educated and the young-that is, marginally attached workers. ${ }^{5}$

Haltiwanger suggested that these findings were potentially connected with those of Austin, Glaeser, and Summers. Haltiwanger and Davis found evidence that there were especially large declines in fluidity measures for exactly those kinds of marginally attached workers, along with declines in their employment-to-population ratios. They also found-very much consistent with the present paper's findings - that the spatial variations in employment-to-population ratios were closely connected to variation fluidity. That is, in areas where these ratios fell a lot, there are also significant declines in measures of labor market fluidity. Knowing more about what is happening to labor market fluidity in these places could shed light on what market failures or bad policies exist. One such policy could be the dramatic rise in occupational licensing, which has a significant spatial component because of its state-specific aspects. Reforming occupational licensing will not solve all the problems, but it is useful to examine these types of covariates in thinking about the kinds of distortionary policies-even those that are well intentioned - and to consider what can be done to alleviate some of the problems.

David Autor highlighted the importance of agglomeration. He believes it is important to understand why these places have become so much worse and why labor market rigidities have become so much greater. The authors stated that, 30 years ago, they would not have favored the types of placebased policies they now write about, but that now they would, based on the data. But Autor yearned for a theory to explain what happened in those 30 years. Is it bad policy, such as occupational licensing and labor market rigidities, or does it have to do with manufacturing and the decline of highpaid, poorly educated areas? Is it globalization and the creation of megacenters? Is it something about the information economy that is leading agglomeration to become more important than it used to be, or is it just a transition path when the economy shifts from one set of sectors to another?

Alan Blinder made two points. The first was with regard to elasticities. In many of the economically depressed areas that the authors describe, there is a continuum of preferences for moving away-some would like to move, some would not, and many are in between. This seemed to be a very important dimension of the problems the authors discuss. For the people

5. Steven J. Davis and John Haltiwanger, "Labor Market Fluidity and Economic Performance," in Economic Policy Symposium Proceedings: Re-Evaluating Labor Market Dynamics (Jackson Hole, Wyo.: Federal Reserve Bank of Kansas City, 2014). 
who would like to move, things can be done to help them; but these policies would not work for people who do not want to move, which connects to the point made by Rivlin about whether these problems are really about place. The reality is that some people just do not want to move, under any circumstances.

Second, Blinder asserted that it is a clear fact that the attractiveness of places can change over time, for various reasons. One obvious example is the coal running out in West Virginia, which caused people employed in that industry to lose their jobs. It also used to be important to be near a harbor because everything came by ship, but that is less true today. Another example is the Sunbelt states: It used to be impossible to live in Arizona without air-conditioning, but Arizona is now quite an attractive place to live; in fact, Phoenix is now one of the most populous cities in the United States. Place-based policies should probably avoid trying to keep people in places that are becoming obsolete, he concluded.

Robert Gordon emphasized the serious question of how to choose the places to target for place-based policies. There is the paradigm of the "hollows of West Virginia." But consider the South Side of Chicago, where 46 percent of men age 20-34 are neither in school nor at work, and where there are food and health deserts. Consider Baltimore and Saint Louis, areas with even higher homicide rates than the South Side of Chicago. It is important to make a distinction in place-based policies once the place is chosen. What is the right place-based policy for Chicago, Baltimore, or Saint Louis? Should they receive food subsidies, or job training for jobs that do not exist? Should consumption be emphasized, such as by subsidizing supermarkets in food deserts; or should production be subsidized, such as by seeking to attract Amazon warehouses?

Another problem, Gordon noted, is the issue of local public finance. Dying areas typically have many unfunded pension obligations, causing a fiscal death spiral. Would places be better served by policies to counteract these spirals? There are alternatives, which Blinder mentioned, such as subsidizing moving, mortgages, or down payments for houses in new areas-particularly in the South, where housing is cheap. All these things are complications of the authors' admirable desire to design place-based policies, he concluded.

Martin Baily has always been skeptical about place-based policies. But in Europe, areas where old industries collapsed look very different from similar places in the United States, which Baily argued is largely due to place-based policies. It is also the case that Europe did not experience the large decline in labor force participation among men, the rise in economic 
despair, and the opioid crisis. Therefore, one should not dismiss placebased policies on the grounds that they did not work in Europe, though Baily qualified his statement by asserting that there are certainly cases where they have not worked. He also noted that people often stop paying their mortgages if their home's value drops below a certain point; even in places where one is required by law to pay one's mortgage, the banks will not go after those who default because it is just not worth the effort.

Robert Hall noted that the thrust of the discussion thus far was that one cannot have place-based policies without discussing what is wrong with the places themselves. The great benefit of the present paper, he noted, is that it provides a way of thinking about the issue that does not require diagnosing the problems of particular places, which everyone agreed was very difficult. Rather, one can simply identify the places and figure out a corrective wage subsidy, without having to know anything more about the place, which Hall thought was ingenious.

Louise Sheiner recalled a visit to Brookings by J. D. Vance, during which he explained that it is not correct to say that people just do not want to move; rather, it is that people do not want to move to places with significant cultural differences-such as from the eastern heartland to the coasts. ${ }^{6}$ Vance advocated for a place-based policy that would, for example, bring an economic hub closer to where the people are, rather than making them move to the coasts. That way, they could stay closer to their cultural homes.

Isabel Sawhill suggested there might be a reservation wage problem that is culturally hard to overcome and that is leading to longer spells of nonemployment. For example, if a factory closes down where employees were making relatively high wages, it may be culturally difficult to adjust to a large drop in wages. She did not know of a way around this problem. But she suggested this reservation wage problem might provide more of a rationale for place-based policies because high reservation wages are similar to the sticky wage theory of why countercyclical fiscal policy is used at the national level.

Sawhill was glad the paper discussed wage subsidies and the Earned Income Tax Credit for childless adults. She was intrigued by the idea of

6. Camille Busette, J. D. Vance, and William Julius Wilson, "Race, Class and Culture: A Conversation with William Julius Wilson and J. D. Vance," Brookings, Washington, September 5, 2017; J. D. Vance, Hillbilly Elegy: A Memoir of a Family and Culture in Crisis (New York: HarperCollins, 2016). 
wage subsidies and wage insurance, and wondered how to make them as effective as possible. Appealing to behavioral economics, it may be the case that including a higher wage in the paycheck itself may have a different effect on employment than, say, the Earned Income Tax Credit, which provides a once-per-year boost in earnings. She believes economists tend to be too analytical about how people behave and what kinds of transparency they need to behave in intended ways.

Sawhill was concerned that the authors' omission of women from the analysis could be problematic. Recent data and research show that women are the ones going to work in distressed communities, and that they are generally better educated than men. Perhaps women, then, are taking some of the new jobs for which men are not qualified. She also agreed with those who suggested that the authors say more about retraining and the role of community colleges.

Christopher Carroll noted that there used to be much greater differences in living standards across different places; the discussion had treated the decline in migration as though it is a mysterious, exogenous occurrence. But one plausible reason for a decline in migration is that the United States now has a strong social safety net that reduces geographical income differences. A structural model that captured the effects of geographical wage differences on migration could be informative about the extent to which people's behavior would respond to wage subsidies and other inducements. If the amount needed to get them to move is high, then perhaps the size of the required wage subsidy needed to change their behavior would also be high.

Glaeser was particularly grateful for Hall's comments about diagnosis, which he said were "exactly on point." The authors received some pushback for not having a narrative-which, in some sense, reflected the fact that they did not agree on all issues-but there is also the question of what narrative one wants. A key question is what explains the rise in joblessness across the United States. Katharine Abraham and Melissa Kearney's recent paper on this question is probably the best out there, and the authors were not trying to reproduce that paper. ${ }^{?}$

A second question is what explains the changing urban fortunes throughout the United States. Glaeser has spent much of his adult life studying this

7. Katharine G. Abraham and Melissa S. Kearney, "Explaining the Decline in the U.S. Employment-to-Population Ratio: A Review of the Evidence," Working Paper no. 24333 (Cambridge, Mass.: National Bureau of Economic Research, 2018). 
question, and he is a firm believer that education is a very strong predictor of which places have done well, whether in the 1960s, the 1940s, or the 1850s. There is a hypothesis associated with research by Theodore Schultz and Finis Welch that education is partially about the ability to adapt to new circumstances, which Glaeser thought was applicable to thinking about which places are able to recover from labor demand and industrial shocks. ${ }^{8}$ Evidence suggests that this is true at the local as well as the individual levels.

A third question is what explains the heterogeneity in joblessness, which is a different question than, say, why Las Vegas has grown so much relative to Boston. The answer is likely a combination of labor demand and labor supply. Glaeser would point strongly toward human capital and institutional differences, such as occupational licensing requirements and right-to-work laws. But the fundamental point is if you believe Gordon's argument that there are externalities associated with nonemployment, then this provides a case for a Pigouvian tax or subsidy, regardless of whether one understands why there is economic heterogeneity. ${ }^{9}$ One does not need to know why traffic congestion has increased to know that a tax on traffic congestion is a good idea, to take a recent example from Mangalore, India. ${ }^{10}$ No part of William Vickrey's original paper on congestion pricing said that one needed to understand the underlying traffic engineering. ${ }^{11}$

Glaeser next turned to the case for subsidizing. Is there a case for differentially subsidizing one area over another, as suggested by Mankiw? Also, related to Furman's comments, would such a plan be politically manageable? One area where Glaeser and Summers differ is that Glaeser is in favor of giving something to West Virginia but also taking something else away. In this sense, he is not for differential subsidization. Regardless of whether such a policy was conceivable, it does not necessarily mean that one region is favored over another.

Taking into account the political economy concerns, Glaeser speculated on what he would be willing to settle for if he were not able to achieve

8. Theodore W. Schultz, "The Value of the Ability to Deal with Disequilibria," Journal of Economic Literature 13, no. 3 (1975): 827-46; Finis Welch, "Education in Production," Journal of Political Economy 78, no. 1 (1970): 35-59.

9. Robert J. Gordon, "The Welfare Cost of Higher Unemployment," Brookings Papers on Economic Activity, no. 1 (1973): 133-95.

10. Violet Pereira, "DC Planning to Introduce Electronic Road Pricing System for Private Vehicles," Mangalorean, February 6, 2018.

11. William S. Vikrey, "Pricing in Urban and Suburban Transport," American Economic Review 53, no. 2 (1963): 452-65. 
regionally targeted proemployment policies. He was not willing to settle for infrastructure investment as a substitute, but was open to considering a national employment subsidy that is flat in nominal terms and has more bite in places with low costs.

Glaeser also considered the comments in favor of mobility across space. He generally agreed with them, but warned that one needs to be careful to remember that encouraging the out-migration of skilled workers from West Virginia is obviously not a winner for that region. He concluded by reiterating that his overall commitment was not to fix every place that is not growing more quickly. For example, there is no policy justification for having everyone live in the foothills of West Virginia, or in getting Detroit's population back from 850,000 to 1.8 million. Rather, the goal is to reduce social dysfunction by creating somewhat more incentive to work versus not work.

Summers began by addressing Hall's concerns about the distinction between unemployment and not being in the labor force. Even before Christopher Flinn and James Heckman wrote their seminal paper on this very question in 1983, Summers and many others were aware that the average person who is out of the labor force is less likely to get a job compared with the average unemployed person. ${ }^{12}$ Rather, the issue is whether the long-term unemployed should be thought of as similar to people who are not in the labor force, or whether to look at only those not in the labor force and to ignore differences in long-term unemployment. Summers found Hall's facts that about 32 percent of those who want a job and are available and 42 percent of the long-term unemployed find a job within a year to be stronger evidence in favor of the kind of aggregation in which the authors were engaged than he would have expected.

On migration, Summers agreed with Glaeser that when migration is encouraged, it is usually the most able, energetic, catalytic people who end up moving, and so it is not clear whether that is a good thing. The economic argument that if people leave a place like Allentown, Pennsylvania, this will cause wages to go up due to labor scarcity there, given the fixed decay in capital stock, may just be wrong. All this is to say that the notion that spurring migration is the right policy is not clear.

Another big theme of their paper-and one about which Summers and Glaeser had different instincts-is that from a certain perspective, a rigid

12. Christopher J. Flinn and James J. Heckman, "Are Unemployment and Out of the Labor Force Behaviorally Distinct Labor Force States?" Journal of Labor Economics 1, no. 1 (1983): 28-42; Kim B. Clark and Lawrence H. Summers, "Labor Market Dynamics and Unemployment: A Reconsideration," Brookings Papers on Economic Activity, no. 1: 13-60. 
wage looks like a perfectly elastic supply curve; but the welfare analysis of these two things produces very different conclusions. Thus, Summers was less enamored than Glaeser of the Baily-Chetty analysis and preferred the evidence that employment can be better stimulated if demand shifts from areas with high employment rates to those with lower rates.

Summers then turned to the discussion about education. The fact is that if you are college educated, it is good to be near other people who are college educated; but if you are not college educated, it is also good to be near people who are college educated. Therefore, a place will likely succeed if it has many college-educated people. This is great to know if you are an adviser to the mayor of a city or the governor of a state. But from the national point of view, there is very little scope to affect the average education of the population in 10 to 15 years. So the question is what is the optimal distribution of educated people-and its answer depends on the curvature of many functions whose very existence is difficult to identify conclusively. Therefore, all arguments of this form do not seem to him to be very convincing.

Although Summers appreciated the argument that, in some analytical sense, the authors can sidestep diagnoses, he argued that if some places are, for example, culturally prone to have many opioid addicts, then that is quite a different situation, in terms of the policy inference one should draw, than if some places have many discouraged workers who have long had difficult times. Summers was more inclined than Glaeser to run with the fact that places with low employment rates are also places with low wages, which would tend to suggest the importance of demand shocks. However, it is not clear that the places with low wages are not also places with low human capital. It may be that low human capital explains both the low wages and the low employment rate, a hypothesis that Summers believes is worth more study.

Summers agreed with everything that was said about the political economy challenges associated with place-based policies. It is also correct that the United States does have place-based policies, in the sense that nominal dollars affect places differently due to price differences. If it is true that the United States has gone from an era of very high natural convergence to one of very low natural convergence, and if for the most problematic phenomenon-nonemployment - there is no convergence at all, one should probably be more enthusiastic about place-based policies. The current state of place-based policies is not optimal, and Summers accepted Furman's argument that there is a tendency toward the triumph of hope over experience, which he believes is a problem. 
Though not the focus of the present paper, Summers thinks it is important to understand the relevant international experiences, and he was delighted to hear Baily corroborate his views. But he was surprised because he had always thought that the experiences of northern Britain and southern Italy tended to suggest that these problems were difficult to solve, that Europe had much trouble with these types of policies. Therefore, he was still not completely confident that international experience confirms the problems of place-based policies.

Summers concluded by saying that the authors believe they have served their purpose entirely if they have successfully made the case that the magnitude of regional differentials and the significant parts of the country where large fractions of men are not working should command more thought from economists than they traditionally receive. From the many constructive comments received, he took it that they had perhaps helped to nudge the conversation in that direction. 